\title{
Pengantar Sistem Ekonomi Islam
}

PENULIS:

KUMARAADJI KUSUMA 
Pengantar Sistem Ekonomi Islam

\author{
Penulis:
}

Dr. Kumara Adji Kusuma, S.Fil.I, CIFP

Diterbitkan oleh:

UMSIDA PRESS 


\section{Kata Pengantar}

Ungkapan pujian dan terima kasih hanya kepada Allah SWT atas berkah rahmat dan hidayahNya sehingga buku ajar ini bisa terwujud. Buku ajar ini merupakan buku penunjang perkuliahan pada Program Studi Akuntansi, Fakultas Ekonomi dan Bisnis, Universitas Muhammadiyah Sidoarjo.

Buku ini dikembangkan berdasarkan pada konsep dasar ekonomi Islam yang lahir bukan sebagai sebuah pengetahuan baru. Ekonomi Islam merupakan sebuah konsep keilmuan Islam yang telah dipraktekkan sejak masa Rasulullah yand dilanjutkan oleh para sahabatnya yang dibingkai dalam konteks sains ekonomi modern. Dengan kata lain ekonomi Isalam adalah ekonomi lama yang didasarkan atas wahyu Allah yang dibingkai dalam konteks ilmiah (scientific). Ekonomi Islam membentangkan pengetahuan bagaimana seorang Muslim harus bertindak secara ekonomi sehingga bisa mewujudkan kehidupan yang kaffah dismping keilmuan Islam lainnya.

Akhir kata, penulis menyadari bahwa buku ini masih banyak kekurangan. Oleh karena itu, kritik dan saran yang membangun dari pembaca sangat diharapkan demi 
perbaikan buku ini. Penulis juga mengucapkan terima kasih kepada Universitas Muhammadiyah Sidoarjo yang menerbitkan buku bahan ajar Pengantar Ekonomi Islam ini.

Sidoarjo, Juni 2019

Penulis 


\section{Daftar Isi}

$\begin{array}{ll}\text { Kover } & 0\end{array}$

Identitas Buku i

Kata Pengantar ii

Daftar Isi iv

Kerangka Ajaran Islam 1

Kritik Atas Sistem Kapitalis Dan Sosialis 6

Sistem Ekonomi Kapitalis $\quad 11$

Sistem Ekonomi VS IImu Ekonomi 24

Sistem Ekonomi Sosialis $\quad 41$

$\begin{array}{ll}\text { EKONOMI } & 61\end{array}$

Asas Sistem Ekonomi 63

Pandangan Islam Terhadap Ekonomi 65

$\begin{array}{ll}\text { Politik Ekonomi Islam } & 67\end{array}$

Kaidah Umum Perekonomian $\quad 77$

JENIS-JENIS KEPEMILIKAN: KEPEMILIKAN INDIVIDU (PRIVATE PROPERTY) 82

Batasan Kepemilikan Individu 83

Makna Kepemilikan 86

MEKANISME MEMANAGE HARTA 92

Hak Memanage $\quad 92$

Pengembangan Kepemilikan 93 
Berproduksi

Daftar Pustaka

\section{Kerangka Ajaran Islam}

Pokok ajaran Islam ada 3, yaitu: Iman, Islam dan Ihsan. Dasarnya adalah hadits sebagai berikut:

Pada suatu hari kami (Umar Ra dan para sahabat Ra) duduk-duduk bersama Rasulullah Saw. Lalu muncul di hadapan kami seorang yang berpakaian putih. Rambutnya hitam sekali dan tidak tampak tanda-tanda bekas perjalanan. Tidak seorangpun dari kami yang mengenalnya. Dia langsung duduk menghadap Rasulullah Saw. Kedua kakinya menghempit kedua kaki Rasulullah, dari kedua telapak tangannya diletakkan di atas paha Rasulullah Saw, seraya berkata, "Ya Muhammad, beritahu aku tentang Islam." Lalu Rasulullah Saw menjawab, "Islam ialah bersyahadat bahwa tidak ada tuhan kecuali Allah dan Muhammad Rasulullah, mendirikan shalat, menunaikan zakat, puasa Ramadhan, dan mengerjakan haji apabila mampu." Kemudian dia bertanya lagi, "Kini beritahu aku tentang iman." Rasulullah Saw 
menjawab, "Beriman kepada Allah, malaikat-malaikat-Nya, kitab-kitab-Nya, rasul-rasul-Nya, hari akhir dan beriman kepada Qodar baik dan buruknya." Orang itu lantas berkata, "Benar. Kini beritahu aku tentang ihsan." Rasulullah berkata, "Beribadah kepada Allah seolah-olah anda melihat-Nya walaupun anda tidak melihat-Nya, karena sesungguhnya Allah melihat anda. Dia bertanya lagi, "Beritahu aku tentang Assa'ah (azab kiamat)." Rasulullah menjawab, "Yang ditanya tidak lebih tahu dari yang bertanya." Kemudian dia bertanya lagi, "Beritahu aku tentang tanda-tandanya." Rasulullah menjawab, "Seorang budak wanita melahirkan nyonya besarnya. Orang-orang tanpa sandal, setengah telanjang, melarat dan penggembala unta masing-masing berlomba membangun gedung-gedung bertingkat." Kemudian orang itu pergi menghilang dari pandangan mata. Lalu Rasulullah Saw bertanya kepada Umar, "Hai Umar, tahukah kamu siapa orang yang bertanya tadi?" Lalu aku (Umar) menjawab, "Allah dan rasul-Nya lebih mengetahui." Rasulullah Saw lantas berkata, "Itulah Jibril datang untuk mengajarkan agama kepada kalian." (HR. Muslim)

\section{a. Rukun Iman 6 Perkara}

Iman adalah keyakinan kita pada 6 rukun iman. Islam adalah pokok-pokok ibadah yang wajib kita kerjakan. Ada pun Ihsan adalah cara mendekatkan diri kita kepada Allah.

Tanpa iman semua amal perbuatan baik kita akan sia-sia. Tidak ada pahalanya di akhirat nanti:

" Dan orang-orang kafir amal-amal mereka adalah laksana fatamorgana di tanah yang datar, yang disangka air oleh 
orang-orang yang dahaga, tetapi bila didatanginya air itu dia tidak mendapatinya sesuatu apapun..." [An Nuur/24:39]

" Orang-orang yang kafir kepada Tuhannya, amalan-amalan mereka adalah seperti abu yang ditiup angin dengan keras pada suatu hari yang berangin kencang. Mereka tidak dapat mengambil manfaat sedikitpun dari apa yang telah mereka usahakan (di dunia). Yang demikian itu adalah kesesatan yang jauh." [Ibrahim/14:18]

Iman ini harus dilandasi ilmu yang mantap sehingga kita bisa menjelaskannya kepada orang lain. Bukan sekedar taqlid atau ikut-ikutan.

Sebagaimana hadits di atas, rukun Iman ada 6. Pertama Iman kepada Allah. Artinya kita meyakini adanya Allah dan tidak ada Tuhan selain Allah. Di bab-bab berikutnya akan dijelaskan secara rinci tentang hal ini.

Rukun Iman yang kedua adalah iman kepada Malaikat-malaikat Allah. Kita yakin bahwa Malaikat adalah hamba Allah yang selalu patuh pada perintah Allah.

Rukun Iman yang ketiga adalah beriman kepada Kitab-kitab-Nya. Kita yakin bahwa Allah telah menurunkan Taurat kepada Musa, Zabur kepada Daud, Injil kepada Isa, dan Al Qur'an kepada Nabi Muhammad. Namun kita harus yakin juga bahwa semua kitab-kitab suci di atas telah dirubah oleh manusia sehingga Allah kembali menurunkan Al Qur'an yang dijaga kesuciannya sebagai pedoman hingga hari kiamat nanti. 
"Maka kecelakaan yng besar bagi orang-orang yang menulis Al Kitab dengan tangan mereka sendiri, lalu dikatakannya; "Ini dari Allah", dengan maksud untuk memperoleh keuntungan yang sedikit dengan perbuatan itu. Maka kecelakaan yang besarlah bagi mereka, akibat apa yang ditulis oleh tangan mereka sendiri, dan kecelakaan yang besarlah bagi mereka, akibat apa yang mereka kerjakan." [Al Baqarah/2:79]

Kita harus meyakini kebenaran Al Qur'an dan mengamalkannya:

"Kitab Al Quran ini tidak ada keraguan padanya; petunjuk bagi mereka yang bertaqwa" [Al Baqarah/2:2]

Rukun Iman yang keempat adalah beriman kepada Rasul-rasul (Utusan) Allah. Rasul/Nabi merupakan manusia yang terbaik yang pantas dijadikan suri teladan yang diutus Allah untuk menyeru manusia ke jalan Allah. Ada $25 \mathrm{Nabi}$ yang disebut dalam Al Qur'an yang wajib kita imani di antaranya Adam, Nuh, Ibrahim, Musa, Isa, dan Muhammad.

Karena ajaran Nabi-Nabi sebelumnya telah dirubah ummatnya, kita harus meyakini bahwa Nabi Muhammad saw adalah Nabi terakhir yang harus kita ikuti ajarannya.

" Muhammad bukanlah bapak dari seorang laki-laki di antara kamu, tetapi dia adalah Rasulullah dan penutup nabi-nabi..." [Al Ahzab/33:40]

Rukun Iman yang kelima adalah beriman kepada Hari Akhir (Kiamat/Akhirat). Kita harus yakin bahwa dunia ini fana. Suatu saat akan tiba hari Kiamat. Pada saat itu manusia akan 
dihisab. Orang yang beriman dan beramal saleh masuk ke surga. Orang yang kafir masuk neraka.

Selain kiamat besar kita juga harus yakin akan kiamat kecil yaitu mati. Setiap orang pasti mati. Untuk itu kita harus selalu hati-hati dalam bertindak.

Rukun Iman yang keenam adalah percaya kepada

Takdir/qadar yang baik atau pun yang buruk. Meski manusia wajib berusaha dan berdoa, namun apa pun hasilnya kita harus menerima dan mensyukurinya sebagai takdir dari Allah.

b. Rukun Islam 5 Perkara

Ada pun rukun Islam terdiri dari 5 perkara. Barang siapa yang tidak mengerjakannya maka Islamnya tidak benar karena rukunnya tidak sempurna.

Rukun Islam pertama yaitu bersaksi bahwa tidak ada Tuhan selain Allah dan Muhammad adalah utusan Allah. Asyhaadu alla ilaaha illallaahu wa asyhaadu anna muhammadar rasuulullaah. Artinya kita meyakini hanya Allah Tuhan yang wajib kita patuhi perintah dan larangannya. Jika ada perintah dan larangan dari selain Allah, misalnya manusia, yang bertentangan dengan perintah dan larangan Allah, maka Allah yang harus kita patuhi. Ada pun Muhammad adalah utusan Allah yang menjelaskan ajaran Islam. Untuk mengetahui ajaran Islam yang benar, kita berkewajiban mempelajari dan mengikuti ajaran Nabi Muhammad.

Konsekwensi dari 2 kalimat syahadat adalah kita harus mempelajari dan memahami Al Qur'an dan Hadits yang sahih 
(minimal Kutuubus sittah: Bukhari, Muslim, Abu Daud, Tirmidzi, An Nasaa'i, dan Ibnu Majah) dan mengamalkannya.

Rukun Islam kedua adalah shalat 5 waktu, yaitu: Subuh 2 rakaat, Dzuhur dan Ashar 4 raka'at, Maghrib 3 rakaat, dan Isya 4 raka'at. Shalat adalah tiang agama barang siapa meninggalkannya berarti merusak agamanya.

Rukun Islam ketiga adalah puasa di Bulan Ramadhan. Yaitu menahan diri dari makan, minum, hubungan seks, bertengkar, marah, dan segala perbuatan negatif lainnya dari subuh hingga maghrib.

Rukun Islam keempat adalah membayar zakat bagi para muzakki (orang yang wajib pajak/mampu). Ada pun orang yang mustahiq (berhak menerima zakat seperti fakir, miskin, amil, mualaf, orang budak, berhutang, Sabilillah, dan ibnu Sabil) berhak menerima zakat. Zakat merupakan hak orang miskin agar harta tidak hanya beredar di antara orang kaya saja.

Rukun Islam yang kelima adalah berhaji ke Mekkah jika mampu. Mampu di sini dalam arti mampu secara fisik dan juga secara keuangan. Sebelum berhaji, hutang yang jatuh tempo harus dibayar dan keluarga yang ditinggalkan harus diberi bekal yang cukup. Nabi berkata barang siapa yang mati tapi tidak berhaji padahal dia mampu, maka dia mati dalam keadaan munafik.

c. Ihsan Mendekatkan Diri kepada Allah

Ada pun Ihsan adalah cara agar kita bisa khusyuk dalam beribadah kepada Allah. Kita beribadah seolah-olah kita 
melihat Allah. Jika tidak bisa, kita harus yakin bahwa Allah SWT yang Maha Melihat selalu melihat kita. Ihsan ini harus kita terapkan dalam kehidupan sehari-hari sehingga jika kita berbuat baik, maka perbuatan itu selalu kita niatkan untuk Allah. Sebaliknya jika terbersit niat kita untuk berbuat keburukan, kita tidak mengerjakannya karena Ihsan tadi.

Orang yang ihsannya kuat akan rajin berbuat kebaikan karena dia berusaha membuat senang Allah yang selalu melihatnya. Sebaliknya dia malu berbuat kejahatan karena dia selalu yakin Allah melihat perbuatannya.

Itulah sekilas pokok-pokok dari ajaran Islam. Semoga kita semua bisa memahami dan mengamalkannya. Insya Allah dalam bab-bab selanjutnya beberapa hal di atas akan dibahas lebih rinci lagi.

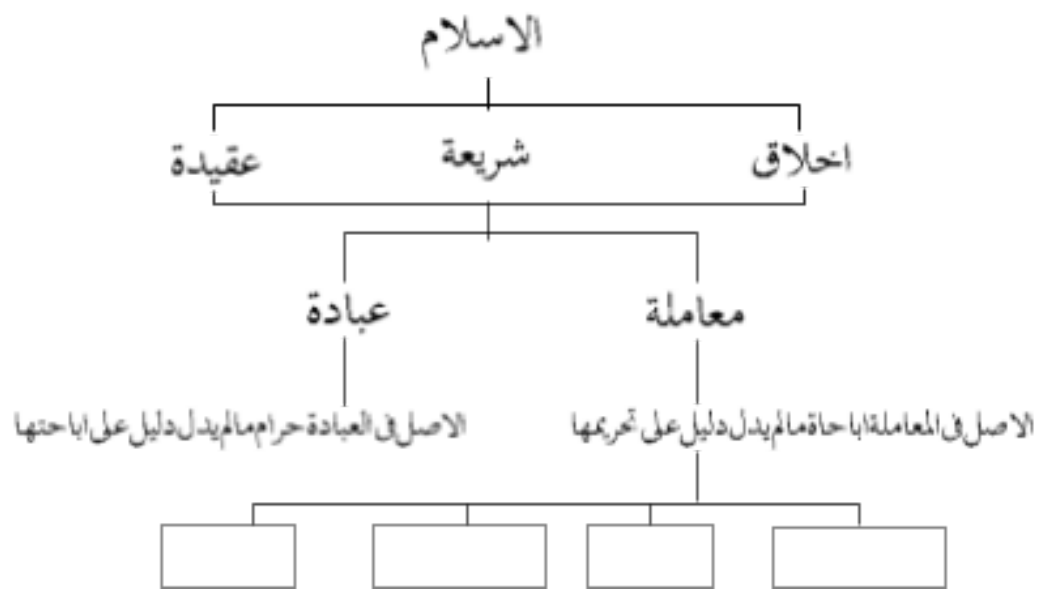




\section{Kritik Atas Sistem Kapitalis Dan Sosialis}

Pemikiran, bagi umat manapun, adalah sebuah kekayaan yang tak ternilai harganya yang mereka miliki dalam kehidupan mereka, apabila mereka adalah sebuah umat yang baru lahir. Bahkan, ia merupakan peninggalan yang demikian berharga yang akan diwarisi oleh generasi penerusnya, apabila umat itu telah menjadi sebuah umat yang memiliki identitas dalam bentuk pemikirannya yang maju.

Sedangkan kekayaan yang bersifat materi, penemuan-penemuan ilmiah, perekayasaan industri serta hal-hal yang lainnya, masih jauh kedudukannya dibanding dengan pemikiran. Bahkan, semuanya bisa diraih melalui pemikiran, dan semata-mata bisa dilestarikan hanya oleh pemikiran.

Oleh karena itu, apabila kekayaan sebuah umat yang bersifat materi hancur, maka dengan segera akan bisa dipulihkan kembali, selama umat itu melestarikan kekayaan berfikir mereka. Namun apabila kekayaan berfikir mereka telah terabaikan, dan sebaliknya, mereka malah melestarikan kekayaan materi, maka kekayaan itu pun akan segera sirna dan mereka akan kembali menjadi miskin. Seperti halnya kebanyakan penemuan-penemuan ilmiah yang telah ditemukan oleh bangsa tersebut, mungkin saja akan terulang kembali, apabila bangsa tersebut telah meninggalkan penemuan-penemuan itu, dengan tidak meninggalkan metode berfikirnya. Sebaliknya, apabila mereka telah meninggalkan metode berfikirnya yang inovatif tersebut, maka pasti mereka akan segera terbelakang lagi. Sehingga 
penemuan-penemuan yang mereka miliki itu akan musnah. Karena itulah, maka yang harus dijaga pertama kali adalah pemikiran. Sehingga dengan dasar pemikiran ini, beserta metode berfikirnya yang inovatif itu, mereka akan bisa meraih sukses dalam bidang materi serta berhasil menemukan penemuan-penemuan ilmiah dan perekayasaan industria (yang sedemikian maju) maupun hal-hal yang serupa lainnya.

Yang dimaksud dengan pemikiran di sini adalah adanya aktivitas berfikir pada diri umat tentang realitas kehidupan yang mereka hadapi. Dimana mereka masing-masing secara keseluruhan senantiasa mempergunakan informasi/ pengetahuan yang mereka miliki, ketika mengindera berbagai fakta ataupun fenomena untuk menentukanhakekat fakta atau fenomena tersebut. Dengan kata lain, mereka senantiasa harus memiliki pemikiran yang bisa mereka gunakan dalam menatap kehidupan mereka.

Sehingga karena sedemikian seringnya mereka mempergunakan pemikiran yang cemerlang, maka akan muncul metode berfikir yang inovatif pada diri mereka.

Umat Islam saat ini bisa dianggap sebagai umat yang telah kehilangan pemikirannya, sehingga pasti mereka telah kehilangan metode berfikirnya yang inovatif. Oleh karena itu, generasi umat saat ini tidak pernah mewarisi pemikiran Islam, maupun pemikiran non Islam apapun dari pendahulu mereka. Dan tentu saja mereka juga tidak akan pernah mewarisi satu metode berfikir yang inovatif. Denagn kata lain, mereka tidak memiliki pemikiran dan metode berfikir yang inovatif sama sekali. Karena itu, secara pasti umat ini nampak telah menderita kemiskinan, sekalipun kekayaan materi di 
negeri mereka sangat berlimpah. Mereka juga nampak telah kehilangan kreativitasnya, sehingga tidak bisa

menemukan penemuan-penemuan ilmiah, maupun melakukan perekayasaan industrialisasi, meskipun secara teoritis mereka mepelajari, mendengarkan dan menyaksikan penemuan-penemuan tersebut. Mengapa, karena mereka tidak akan terdorong untuk melakukannya, kecuali apabila mereka memiliki metode berikir yang inovatif. Yaitu, apabila mereka memiliki pemikiran produktif yang mereka gunakan dalam kehidupan.

Berdasarkan hal ini, kaum Muslimin harus membangun pemikiran dan metode berfikir yang inovatif itu dalam diri mereka. Kemudian dengan landasan pemikiran itu, mereka bisa meraih kekayaan yang besifat materi. Mereka juga akan bisa menemukan realitas-realitas ilmiah. Setelah itu baru kemudian mereka bisa melakukan perekayasaan industrialisasi. Selama mereka tidak melakukannya, niscaya mereka tetap tidak akan mungkin melangkah maju setapak pun. Bahkan, mereka tetap akan berputar di tempat yang akan menghabiskan tenaga dan pemikiran serta berakhir di tempat semula, kemudian berputar lagi, begitu seterusnya.

Generasi umat Islam dewasa ini tidak memiliki pemikiran-pemikiran yang berlawanan dengan pemikiran yang ingin diwujudkan pada dirinya, sehingga generasi itu mampu menyadari (hakikat) pemikiran yang akan disampaikan kepadanya. Dengan begitu, akan terjadi pertarungan antara dua pemikiran, lalu dia mampu menemukan pemikiran yang benar. Kenyataannya tidaklah demikian, justru generasi ini telah kehilangan semua pemikiran beserta seluruh metode berfikirnya yang inovatif. 
Dimana generasi ini telah mewarisi pemikiran-pemikiran Islam sebagai filsafat yang bersifat utopis, sebagaimana bangsa Yunani yang --pada saat ini-- telah mewarisi filsafat Aristoteles dan Plato. Generasi ini juga telah mewarisi Islam sebagai sebuah upacara dan simbol-simbol keagamaan, seperti halnya orang-orang Nasrani yang telah mewarisi agama Nasraninya. Sementara pada saat yang sama, generasi ini telah terpesona dengan pemikiran Kapitalis, karena melihat keberhasilannya, bukan karena memahami betul realitas pemikirannya. Juga karena generasi ini telah tunduk pada sistem dan hukum kapitalis, bukan karena menyadari bahwa peraturan-peraturan itu sebenarnya muncul dari pandangan hidup Kapitalis.

Oleh karena itu, mereka sendiri tetap jauh dari pemikiran-pemikiran Kapitalis dilihat dari segi proses berfikirnya, sekalipun mereka menatap kehidupan mereka dengan gaya hidup Kapitalis. Begitu pula, mereka jauh dari pemikiran-pemikiran Islam dari segi praktiknya, sekalipun mereka beragama Islam dan mengkaji pemikiran-pemikirannya.

Kecenderungan mereka terhadap pemikiran-pemikiran tersebut telah melampaui batas, tidak lagi pada usaha untuk mengkompromikan antara Islam dengan hukum-hukum dan solusi-solusi Kapitalis. Bahkan, sampai pada perasaan inferior (rendah diri) terhadap kemampuan Islam untuk melahirkan solusi-solusi bagi problem kehidupan yang senantiasa silih berganti. Yang kemudian melahirkan ketergantungan pada hukum-hukum dan solusi-solusi Kapitalis. Bahkan, tanpa membutuhkan upaya-upaya kompromi lagi, sehingga tidak merasa riskan untuk meninggalkan hukum-hukum Islam dan 
mengadopsi hukum-hukum non-Islam. Tujuanya adalah agar bisa meraih kemajuan dalam percaturan kehidupan, sejajar dengan dunia yang berperadaban tinggi. Juga agar bisa menyusul kelompok bangsa-bangsa Kapitalis atau bangsa-bangsa yang menerapkan Sosialisme dan mneuju ke tahap Kominisme. Dengan menganggap, baik Kapitalis maupun Sosialis itu, sebagai bangsa-bangsa yang maju.

Sedangkan golongan yang amat sedikit dari kalangan mereka yang masih memegang Islam mereka duga memiliki kecenderungan terhadap pemikiran-pemikiran Kapitalis. Akan tetapi, mereka masih mempunyai obsesi tentang kemungkinan untuk mengkompromikan antara Islam dengan Kapitalis dan Sosialis. Hanya sayang sekali, bahwa mereka yang berupaya untuk mengkompromikan antara Islam dengan idiologi non-Islam itu tidak memiliki pengaruh/peranan sama sekali dalam kehidupan masyrakat, dilihat dari segi interkasinya di tengah-tengah kehidupan manusia.

Oleh karena itu, memberikan pemikiran-pemikiran Islam dan hukum-hukum syara' sebagai solusi kehidupan jelas akan mengalami pertarungan dengan manusia yang kosong dari pemikiran dan metode berfikir, juga akan bertarung dengan kecenderungan terhadap pemikiran-pemikiran Kapitalis atau Sosialis termasuk dengan realitas kehidupan sehari-hari yang dikendalikan oleh sistem Kapitalis.

Selama pemikiran itu tidak kokoh hingga betul-betul menancap kuat dalam benak dan akal mereka, maka tidak mungkin pemikiran itu akan menggoncang orang-orang tersebut, bahkan rasanya sulit memalingkan perhatian mereka. Karena dengan pemikiran ini, ia akan mampu 
membawa logika-logika yang lemah plus dangkal itu ke dalam proses berfikir yang mendalam. la juga mampu menggoncang kecenderungan-kecenderungan yang menyimpang serta perasaan yang kacau hingga lahir kecenderungan yang benar, yaitu kepada pemikiran-pemikiran dan hukum-hukum Islam.

Karena itulah, maka seorang pengemban dakwah Islam harus senantiasa memaparkan asas-asas yang menjadi dasar pijakan hukum-hukum dan solusi-solusi Kapitalis. la harus menjelaskan kerusakan-kerusakannya, kemudian menghancurkannya. la juga harus senantiasa mendalami realitas-realitas kehidupan yang silih berganti, kemudian menjelaskan solusi Islam terhadap realitas itu, yang merupakan hukum-hukum syara' yang wajib diambil, dilihat dari fakta bahwa ia merupakan hukum syara' yang digali berdasarkan Kitabullah dan Sunah Rasulullah, atau dalil yang ditunjukkan oleh keduanya. Bukan dari cocok atau tidak cocoknya untuk masa sekarang. Dengan kata lain, ia harus menjelaskan bahwa hukum mengambilnya adalah wajib dilihat dari segi aqidah bukan karena maslahat. Maka, untuk menyampaikannya harus dilandasi dengan penjelasan dalil syara'nya yang menjadi pijakan istimbat-nya, atau penjelasan illat-nya dengan illat syar'iyah, yang telah dinyatakan, maupun yang telah ditunjukkan oleh nash syara' yang serupa.

Masalah paling berat yang telah memalingkan kaum muslimin, serta penyakit paling parah yang mereka derita dalam kehidupan mereka ini adalah masalah pemikiran yang menyangkut persoalan pemerintahan dan ekonomi. Karena pemikiran-pemikiran inilah yang paling banyak diterima dan disambut dengan penuh kebanggaan oleh kaum muslimin. Disamping pemikiran-pemikiran inilah yang paling banyak 
direkayasa oleh Barat agar bisa diterapkan secara praktis, bahkan mereka senantiasa mengawasi upaya penerapannya itu dengan gigih dan terus-menerus. Apabila umat Islam dipimpin dengan mempergunakan sistem Demokrasi secara de jure -dan ini merupakan usaha negara imperialis Kafir supaya penjajahan serta sistem mereka tetap bisa dipertahankan - maka umat Islam secara de facto dipimpin dengan mempergunakan sistem ekonomi Kapitalis pada semua sektor kehidupan perekonomiannya. Karena itu, maka pemikiran-pemikiran Islam tentang ekonomi inilah yang sebenarnya merupakan pemikiran yang paling kuat pengaruhnya dalam kehidupan perekonomian di dunia Islam, dengan alasan bahwa pemikiran inilah yang akan merubah umat secara revolusioner dan pemikiran inlah paling banyak dilawan oleh negara imperialis Kafir beserta kaki tangan dan para pengagum Barat, yakni para penguasa, orang-orang yang tersesat serta mereka yang mejadi pengagum Barat.

Oleh karena itu, kiranya perlu diberikan gambaran yang jelas tentang ekonomi dalam sistem Kapitalis, yang dipergunakan oleh Barat sebagai pemikiran paling mendasar untuk membangun economic policy-nya.

Sehingga para pecandu sistem ekonomi Barat itu bisa mengetahui dengan sendirinya kebobrokan sistem ini dan mereka juga bisa memahami kontradiksinya dengan Islam, yang kemudian mereka bisa melihat dengan jelas pemikiran-pemikiran ekonomi Islam yang bisa memberikan solusi terhadap problem-problem kehidupan perekonomian itu dengan solusi yang tepat, serta menjadikannya sebagai life style yang khas yang bertentangan dengan kehidupan 
Kapitalis, baik menyangkut dasar maupun serpian (furu')-nya yang lain.

\section{Sistem Ekonomi Kapitalis}

Apabila kami paparkan sistem ekonomi dalam pandangan ideologi Kapitalis, maka kita akan menemukan bahwa ekonomi dalam pandangan mereka adalah apa yang membahas tentang kebutuhan-kebutuhan (needs) manusia beserta alat-alat (goods) pemuasnya. Dimana ia sesungguhnya hanya membahas masalah yang menyangkut aspek-aspek yang bersifat materi dari kehidupan manusia.

Sistem itu dibangun dengan tiga kerangka dasar. Pertama, adalah kelangkaan atau keterbatasan barang-barang dan jasa-jasa yang berkaitan dengan kebutuhan manusia. Dimana barang-barang dan jasa-jasa itu tidak mampu atau memiliki keterbatasan untuk memenuhi kebutuhan-kebutuhan manusia yang beraneka ragam dan terus-menerus bertambah kuantitasnya. Dan inilah masalah ekonomi yang dihadapi oleh masyarakat, menurut mereka. Kedua, adalah nilai (value) suatu barang yang dihasilkan, itulah yang menjadi dasar penelitian ekonomi, bahkan yang paling sering dikaji. Ketiga, adalah harga (price) serta peranan yang dimainkannya dalam produksi, konsumsi dan distribusi. Dimana harga merupakan alat pengendali dalam sistem ekonomi Kapitalis.

Mengenai kelangkaan dan keterbatasan barang-barang dan jasa-jasa secara relatif hal itu memang betul ada pada karakteristik barang-barang dan jasa-jasa itu sendiri sebagai alat pemuas kebutuhan-kebutuhan manusia. Mereka mengatakan, bahwa manusia memiliki kebutuhan-kebutuhan yang harus dipenuhi dan karena itu, maka harus ada alat-alat 
pemuasnya. Sedangkan kebutuhan-kebutuhan itu sebenarnya hanya bersifat meteri semata. Karena bisa jadi kebutuhan-kebutuhan itu berupa sesuatu yang bisa dirasakan dan diindera manusia, seperti kebutuhan manusia akan makanan dan pakaian. Juga bisa jadi kebutuhan-kebutuhan yang hanya bisa dirasakan, namun tidak dapat diindera oleh mereka, seperti kebutuhan manusia akan jasa layanan dokter dan guru. Sementara kebutuhan-kebutuhan yang bersifat ma'nawi (non-fisik) seperti rasa bangga dan atau kebutuhan spiritual seperti pensucian/penghormatan yang tertinggi, Semuan itu tidak pernah dikenal keberadaannya menurut sistem ekonomi mereka, bahkan hal itu tidak pernah mereka beri tempat, dan tidak pernah diperhatikan ketika membahas kajian ekonomi tersebut.

Sedangkan alat-alat pemuas yang mereka sebut dengan sebutan barang dan jasa itu adalah, bahwa barang itu esensinya merupakan alat pemuas kebutuhan-kebutuhan yang bisa diindera dan dirasakan. Sementara jasa adalah alat pemuas kebutuhan-kebutuhan yang bisa dirasakan namun tidak bisa diindera. Sedangkan apa yang menyebabkan barang dan jasa itu menjadi alat pemuas? Menurut mereka, yang menyebabkannya adalah kegunaan (utility) yang ada pada barang dan jasa tersebut. Dimana kegunaan (utility) itu bersifat subjektif, yaitu apabila ada barang yang memiliki kegunaan itu, maka barang tersebut layak dipergunakan untuk memenuhi kebutuhan, dilihat dari segi bahwa kebutuhan menurut kaca mata ekonomi mereka itu adalah keinginan. Sehingga barang yang memiliki kegunaan (utility) itu menurut kaca mata ekonomi ini adalah segala sesuatu yang diinginkan, baik yang bersifat primer atau non primer, 
maupun yang dianggap oleh sebagian orang memberi kepuasan (satisfaction) sedangkan menurut sebagian yang lain membahayakan. Maka sesuatu itu menurut kaca mata ekonomi tetap dianggap berguna (memiliki utility), selama masih ada orang yang menginginkannya.

Pandangan inilah yang melahirkan penilaian mereka, bahwa sesuatu itu berguna (memiliki utility tertentu) dari kaca mata ekonomi, sekalipun persepsi umum menganggap tidak bermanfaat atau justru berbahaya. Khamar dan candu, misalnya, adalah sesuatu yang memiliki utility tertentu dalam pandangan para ekonom. Sebab ia masih diinginkan oleh sebagian orang. Maka dengan kerangka inilah, para ahli ekonomi itu berpendapat tentang alat-alat pemuas kebutuhan tersebut. Yaitu dengan melihatnya sebagai barang-barang dan jasa-jasa yang bisa memenuhi kebutuhan saja, tanpa memperhatikan aspek-aspek lain. Dengan kata lain, mereka memandang antara kebutuhan dengan kegunaan (utility) itu sebagai apa adanya, bukan sebagai sesuatu yang dipandangan dengan semestinya. Sehingga mereka hanya memandang kegunaan (utility) itu dari segi bisa memuaskan kebutuhan atau tidak, dan tidak lebih dari sekedar itu. Karena itu, mereka memandang khamar dari segi bahwa khamar itu memiliki nilai ekonomi, sebab khamar itu bisa memuaskan kebutuhan seseorang. Mereka juga memandang industri khamar itu sebagai pemberi jasa, dimana dari segi jasa jelas memiliki nilai ekonomi, karena jasa itu bisa untuk memuaskan kebutuhan individu.

Inilah karakteristik kebutuhan itu menurut kaca mata mereka. Yaitu sebagai alat-alat pemuas kebutuhan. Sehingga para pakar ekonomi Kapitalis tidak pernah memperhatikan 
masalah-masalah yang semestinya harus dijadikan pijakan oleh masyarakat. Sebaliknya, mereka hanya memperhatikan objek pembahasan ekonomi itu dari segi apakah bisa memuaskan kebutuhan atau tidak. Oleh karena itu, perhatian para pakar ekonomi hanya bertumpu pada peningkatan produksi barang-barang dan jasa-jasa. Yaitu meningkatkan --baik secara kuantitatif maupun kualitatif-- alat-alat pemuas itu dalam rangka memenuhi kebutuhan-kebutuhan manusia, tanpa memperhatikan aspek-aspek yang lain. Dengan dasar pijakan inilah, maka para pakar ekonomi tersebut membahas upaya peningkatan produksi alat-alat pemuas kebutuhan manusia. Ketika mereka memandang bahwa alat-alat pemuas itu terbatas, maka alat-alatpemuas itu tidak akan cukup untuk memenuhi dan memuaskan kebutuhan-kebutuhan manusia, karena -- menurut mereka-- kebutuhan itu bersifat tak terbatas. Padahal di sana ada sejumlah kebutuhan pokok (basic needs) yang harus dipenuhi oleh manusia, sebagai manusia yang membutuhkannya. Juga ada sejumlah kebutuhan yang terus meningkat, pada saat taraf kehidupan materi manusia itu terus meningkat hingga sampai pada taraf yang sedemikian tinggi. Hal ini terus berkembang dan meningkat sehingga semuanya membutuhkan pemuasan dengan cara pemuasan yang menyeluruh. Semuanya ini tidak akan pernah terwujud, meskipun barang-barang dan jasa-jasa tersebut jumlahnya --baik secara kuantitatif maupun kualitatif-menigkat terus.

Dari sinilah kemudian muncul pandangan dasar terhadap masalah ekonomi, yaitu banyaknya kebutuhan sementara alat pemuasnya terbatas. Dimana jumlah barang dan jasa --yang secara kuantitatif dan kualitatif itu banyak-- tidak bisa 
memenuhi seluruh kebutuhan manusia secara menyeluruh. Pada saat ini masyarakat akan menghadapi masalah ekonomi, yaitu kelangkaan atau keterbatasan barang-barang dan jasa-jasa secara relatif. Akibat pasti dari kelangkaan dan keterbatasan itu adalah adanya sebagian kebutuhan yang senantiasa terpenuhi secara parsial saja atau bahkan sama sekali tidak terpenuhi.

Selama masalahnya tetap seperti ini, maka harus ada kaidah-kaidah yang digunakan sebagai pijakan oleh anggota masyarakat dalam rangka menentukan, mana kebutuhan-kebutuhan yang akan memperoleh pemenuhan, dan mana kebutuhan-kebutuhan yang harus diabaikan. Dengan kata lain, harus ada kaidah yang dipergunakan untuk menentukan bagaimana cara mendistribusikan barang yang terbatas untuk memnuhi kebutuhan yang tak terbatas itu? Oleh karena itu, bagi mereka masalah sebenarnya adalah kebutuhan-kebutuhan dan barang-barang tersebut, bukan manusianya. Dengan kata lain, masalahnya adalah peningkatan produksi barang untuk memenuhi kebutuhan, bukan memenuhi kebutuhan masing-masing individu.

Selama masalahnya tetap seperti itu, maka harus ada kaidah yang dipergunakan, yaitu kaidah yang bisa menjamin tercapainya tingkat produksi setinggi-tingginya, sehingga peningkatan barang-barang itu bisa diupayakan. Yaitu terpenuhinya barang-barang dan jasa-jasa bagi semua orang, bukan bagi masing-masing orang. Dengan demikian, masalah distribusi barang-barang dan jasa-jasa itu sangat erat kaitannya dengan masalah produksi. Jadi tujuan utama pembahasan ekonomi adalah mengupayakan pertambahan barang-barang dan jasa-jasa yang dikonsumsi oleh seluruh 
manusia. Karena itu, pembahasan tentang faktor-faktor yang mempengaruhi kadar produk nasional akan menduduki tempat terpenting di antara semua tema-tema ekonomi yang lainnya. Karena pembahasan tentang penambahan produk nasional merupakan pembahasan yang paling urgen dalam memecahkan masalah-masalah ekonomi. Yaitu terbatasnya barang-barang dan jasa-jasa bagi kebutuhan manusia. Karena mereka yakin, bahwa tidak akan mungkin bisa memecahkan kemiskinan absolut (absolute poverty) dan kemiskinan struktural, kecuali dengan cara meningkatkan jumlah produksi. Jadi, solusi ekonomi yang dihadapi oleh masyarakat itu hanya dilakukan dengan cara meningkatkan produksi.

Sedangkan nilai barang yang dihasilkan diukur sesuai dengan tingkat kegunaannya, yang bisa jadi berkaitan dengan individu tertentu, bisa jadi juga berkaitan dengan barang lain. Untuk kasus yang pertama sering disebut dengan nilai guna (utility value), sedangkan pada kasus yang kedua sering disebut dengan nilai tukar (exchange value). Adapun tentang utility value itu bisa disimpulkan sebagai satuan dari satu barang, yang diukur berdasarkan kegunaan terakhir benda tersebut, atau kegunaan pada satuan yang dipergunakan untuk memenuhi kebutuhan paling rendah. Inilah yang mereka sebut dengan teori kepuasan batas atau kepuasan akhir (marginal satisfaction theory). Yaitu manfaat, guna atau kepuasan yang tidak ditentukan berdasarkan pandangan produsen, yang nilainya ditentukan sesuai dengan biaya produksinya. Sebab saat itu kegunaan tersebut benar-benar dikendalikan oleh penawaran (supplay) saja dan bukan oleh permintaan (demand). Begitu pula, nilai guna tidak ditentukan berdasarkan pandangan permintaan konsumen 
(demand), sehingga nilainya ditentukan oleh kadar kegunaan yang ada serta kebutuhan konsumen pada kegunaan tersebut, yang didukung faktor kelangkaannya. Karena pada saat itu, nilai dikendalikan oleh permintaan konsumen (demand) saja bukan oleh penawaran (supplay). Semestinya nilai dikendalikan secara seimbang antara permintaan konsumen dan penawaran, sehingga kegunaanya (utility) itu akan didapatkan pada batas unit paling akhir untuk memenuhi kebutuhan --ketika batas akhir pemenuhannya. Dengan kata lain --kalau diibaratkan pada sepotong roti-maka nilai roti itu ditentukan berdasarkan batas titik akhir rasa lapar, bukan pada titik awalnya; juga pada saat persediaan roti itu ada di pasar, bukan pada saat kelangkaannya. Inilah nilai kegunaan (utility value) itu.

Sedangkan nilai tukar (exchange value) bersifat subjektif sekali. Apabila nilai tukar (exchange value) itu ada pada sebuah barang, maka barang itu memiliki nilai yang layak ditukar. Mereka mendefinisikan nilai tukar (exchange value) sebagai kekuatan tukar pada barang, terkait dengan barang lain. Oleh karena itu --kalau diibaratkan pada gandum, terkait dengan jagung-- maka nilai gandum dapat diukur dengan sejumlah jagung yang harus diberikan agar memperoleh sejumlah gandum. Adapun nilai guna (utility value) biasa disebut dengan guna (utility) saja, sedangkan nilai tukar (exchange value) itu disebut dengan nilai (value) saja.

Pertukaran hanya bisa dilakukan secara sempurna, apabila ada alat tukar (medium of exchange) yang dijadikan ukuran untuk barang dan jasa, atau yang memiliki nilai terdekat dengan barang dan jasa tersebut. Dari sinilah, maka menurut para pakar ekonomi Kapitalis, perlunya membahas 
tentang nilai. Sebab, nilai merupakan obyek penukaran dan sifat yang bisa diukur. Disamping itu, karena ia merupakan standar yang dipergunakan untuk mengukur barang-barang dan jasa-jasa (unit of account), serta untuk membedakan aktivitas-aktivitas produktif dan non produktif. Karena produksi adalah penciptaan atau penambahan guna (atas suatu barang). Dimana produksi itu akan sempurna dengan adanya seperangkat kegiatan tertentu. Untuk mengklasifikasikan di antara kegiatan-kegiatan tersebut, antara yang produktif dengan yang non produktif, serta mana yang lebih banyak produktivitasnya daripada yang lain, hal ini membutuhkan standar pecahan (unit of account) bagi barang-barang produksi dan jasa-jasa yang beragam bentuknya. Standar pecahan (unit of account) itu merupakan nilai-nilai kesepakatan bagi barang-barang produksi dan jasa-jasa yang beragam bentuknya. Atau dengan ungkapan lain, alat itu merupakan perkiraan yang disepakati bagi aktivitas tertentu yang dicurahkan, atau jasa tertentu yang diberikan. Dimana perkiraan ini menjadi sesuatu yang sedemikian urgen, karena pada komunitas yang sudah maju, produksi dalam rangka melindungi pertukaran tersebut telah menggeser kedudukan produksi yang berfungsi melindungi masalah konsumsi. Sehingga saat ini, masing-masing orang melakukan pertukaran semua produknya atau sebagian besar produknya dengan barang-barang lain yang diproduksi oleh orang lain.

Pertukaran ini, hanya bisa dilakukan dengan sempurna kalau ada alat tukar (medium of exchange) bagi barang dan jasa. Karena itu dibutuhkan adanya perkiraan nilai pada barang dan jasa, sehingga pertukaran ini bisa sempurna. Oleh 
karena itu mengetahui apa yang dimaksud dengan nilai (value), adalah masalah yang urgen bagi kegiatan produksi dan konsumsi. Dengan kata lain, ia merupakan sesuatu yang sedemikian urgen untuk memenuhi kebutuhan-kebutuhan manusia, melalui alat-alat pemuas kebutuhan tersebut.

Namun demikian, nilai tukar (exchange value) pada saat ini telah dikhususkan pada satuan nilai tertentu sehingga satuan itulah yang menjadi terkenal. Pada komunitas yang sudah maju, nilai-nilai barang itu tidak dinisbatkan pada sebagian benda dengan menggunakan sebagian yang lain, melainkan dinisbatkan kepada benda tertentu yang disebut dengan uang. Sedangkan penisbatan pertukaran barang dengan uang itu disebut dengan harga (price). Maka, harga adalah nilai tukar (exchange value) barang yang dinyatakan dengan uang. Karena itu, dalam hal ini ada perbedaan antara nilai tukar itu sendiri dengan harga. Dimana nilai tukar (exchange value) itu adalah penisbatan pertukaran barang dengan barang-barang lain secara mutlak. Baik barang lain itu berupa uang, barang ataupun jasa. Sedangkan harga adalah nilai tukar (exchange value) barang dengan uang tertentu.

Hal ini membawa konsekuensi, bahwa seluruh harga barang bisa jadi akan membumbung tinggi pada saat yang bersamaan (mengalami inflasi), kemudian pada saat yang lain, secara bersamaan, seluruhnya bisa menjadi turun (mengalami deflasi), ketika pada saat yang sama exchange value-nya mustahil naik dan turun secara bersamaan. Dan bisa jadi harga-harga barang itu berubah, tanpa membawa konsekuensi perubahan exchange value-nya. Oleh karena itu, sebenarnya harga barang adalah salah satu nilai-nilai barang. 
Dengan kata lain, harga merupakan nilai barang yang terkait dengan satuan uang saja.

Maka, ketika harga itu merupakan salah satu nilai, secara pasti harga itu merupakan standar (tolok ukur) bagi barang, apakah barang itu bernilai guna (utility) atau tidak (disutility). Dia juga merupakan standar (tolok ukur) bagi tingkat kegunaan barang itu. Oleh karena itu barang dan jasa itu dinilai memiliki kegunaan dan produktivitas, apabila masyarakat menentukan barang dan jasa tertentu itu dengan harga tertentu. Sedangkan tingkat kegunaannya, diukur dengan harga yang diterima oleh kelompok konsumen yang diberikan kepada produsen untuk memperoleh barang tersebut. Baik barang itu merupakan barang hasil pertanian ataupun industri; baik jasa itu merupakan layanan pedagang, layanan jasa biro angkutan, dokter ataupun insinyur.

Sedangkan peran yang dimainkan oleh harga dalam kegiatan produksi, konsumsi dan distribusi itu --menurut mereka-- adalah karena struktur harga itulah yang menentukan siapa produsen-produsen yang boleh masuk ke dalam area produksi tersebut dan siapa di antara mereka yang tetap akan menjauhi kelompok produsen itu; dengan cara yang sama, ia juga dipergunakan untuk menentukan siapa konsumen yang boleh menikmati pemenuhan kebutuhan-kebutuhannya dan siapa di antara mereka yang kebutuhan-kebutuhannya tetap tidak terpenuhi. Disamping itu beban produksi barang-lah yang menjadi faktor utama yang akan menentukan penawarannya (supplay) di pasar. Sedangkan kegunaan barang adalah faktor utama yang akan menentukan kekuatan permintaan (demand) pasar barang 
tersebut. Dimana masing-masing --baik penawaran maupun permintaan -- akan diukur dengan harga. Karena itu, menurut orang-orang Kapitalis, pembahasan tentang supplay and demand itulah yang menjadi dua pembahasan utama dalam ekonomi. Jadi yang dimaksud dengan supplay and demand adalah supplay and demand di pasar.

Seperti halnya permintaan (demand) tidak mungkin bisa dinyatakan selain dengan menyebut satuan harga, maka begitu pula dengan penawaran (supplay) juga tidak bisa tentukan dengan selain harga. Hanya saja permintaan itu akan berubah dengan kebalikan perubahan harga. Karena itu, apabila harga naik, maka permintaan akan turun, sebaliknya apabila harga turun, maka permintaan akan naik. Berbeda dengan penawaran, sebab penawaran itu akan berubah dengan mengikuti perubahan harga, dan searah dengan perubahan harga tersebut. Dimana, penawaran itu bisa bertambah dengan naiknya harga (di pasar) dan penawaran akan menurun, apabila harga (di pasar) turun. Dalam masing-masing kondisi itu, harga memiliki pengaruh yang dominan dalam supplay and demand. Dengan kata lain, harga memiliki kekuatan yang besar dalam menentukan tingkat produksi dan konsumsi.

Bagi mereka, struktur harga merupakan metode yang paling akurat untuk mendistribusikan barang-barang dan jasa-jasa kepada anggota masyarakat. Karena kegunaan (utility) itu adalah hasil jerih payah yang dicurahkan oleh manusia; sehingga apabila upah itu tidak seimbang dengan kerjanya (jerih payahnya), maka jelas tingkat produksi akan turun. Oleh karena itu, metode yang paling akurat untuk mendistribusikan barang-barang dan jasa-jasa kepada 
anggota masyarakat itulah yang digunakan untuk menjaga tingkat produksi setinggi-tingginya. Dan metode itu adalah metode harga. Itulah yang menurut mereka, disebut dengan struktur harga atau mekanisme harga. Mereka berpendapat bahwa harga itu akan mempengaruhi keseimbangan ekonomi secara otomatis. Sebab mekanisme harga dibangun dengan prinsip membiarkan kebebasan konsumen agar mereka menentukan sendiri distribusi barang-barang yang dimiliki oleh masyarakat, melalui berbagai macam kegiatan ekonomi; karena mereka ingin membeli sejumlah barang tertentu, dan bukan sejumlah barang yang lain. Karena itu, mereka akan membelanjakan pendapatan mereka, yang mereka peroleh untuk membeli apa yang mereka butuhkan dan apa saja yang mereka senangi.

Maka, seorang konsumen yang tidak suka minum khamar, dia tidak akan membelinya, sehingga pendapatannya akan dibelanjakan kepada barang konsumsi yang lain. Dan apabila jumlah konsumen yang tidak suka khamar, atau semua orang menjadi tidak suka kepada khamar, maka jelas produsen khamar akan bangkrut, karena dianggap tidak menguntungkan. Tidak adanya permintaan khamar mengakibatkan produsen khamar akan tutup. Jadi, konsumenlah yang menentukan jumlah serta jenis-jenis produksi, sesuai dengan keinginan mereka. Sementara, dengan harga itulah barang-barang dan jasa-jasa bisa didistribusikan, agar bisa dijangkau oleh para konsumen atau tidak serta agar bisa memberikan (untung) kepada produsen atau tidak.

Dengan demikian, struktur harga itulah yang mendorong laju produksi, dan dialah yang menentukan distribusi (barang 
dan jasa). Dan dialah yang menjadi alat untuk melakukan kontak antara produsen dan konsumen. Dengan kata lain, ia merupakan penyeimbang (balance) antara jumlah produksi dan konsumsi (barang dan jasa).

Sedangkan keberadaan harga sebagai pendorong laju produksi adalah karena yang menjadi pendorong utama manusia melakukan aktivitas dalam bentuk usaha produktif atau untuk melakukan suatu pengorbanan, hal itu ditentukan oleh insentif yang berupa materi untuk mencurahkan tenaga atau pengorbanan tersebut. Para pakar ekonomi Kapitalis, bahkan menjauhi pembahasan aktivitas manusia mencurahkan tenaganya, karena dorongan moral atau spiritual. Adapun dorongan moral yang mereka akui eksistensinya itu pun mereka kembalikan kepada insentif

yang bersifat materi. Mereka berpendapat, bahwa pengorbanan yang dicurahkan oleh manusia itu semata-mata untuk memenuhi kebutuhan-kebutuhan serta keinginan-keinginannya yang bersifat materi. Dimana pemenuhan itu bisa jadi dengan cara mengkonsumsi barang yang langsung dihasilkan, atau bisa jadi dengan cara mendapatkan upah dalam bentuk finansial yang bisa dipergunakan untuk memperoleh barang-barang dan jasa-jasa yang telah diproduksi oleh orang lain.

Dan karena manusia dalam pemenuhan sebagian besar kebutuhannya, jika tidak seluruhnya, senantiasa bergantung kepada pertukaran tenaga dengan tenaga orang lain, maka pemenuhan kebutuhan-kebutuhan tersebut sebenarnya dibangun melalui perolehan upah yang berupa uang dari tenaganya yang diberikan oleh perolehan atas sejumlah barang dan jasa tertentu. Dan bukan dibangun melalui 
perolehan sejumlah barang yang dia hasilkan. Karena itu, upah yang berupa uang itulah (harga) yang menjadi pendorong manusia untuk berproduksi. Oleh karena itu, hargalah yang mendorong para produsen untuk mencurahkan tenaganya. Dengan begitu, hargalah yang esensinya mendorong laju produksi.

Adapun harga yang berfungsi untuk mengatur distribusi (barang dan jasa), adalah karena manusia itu ingin memenuhi seluruh kebutuhannya. Karena itu, dia berusaha untuk meraih sejumlah barang dan jasa yang bisa memenuhi seluruh kebutuhannya. Andaikan tiap orang dibebaskan untuk memenuhi kebutuhan-kebutuhannya, niscaya ia tidak akan pernah berhenti mengumpukan dan mengkonsumsi barang-barang yang dia inginkan. Akan tetapi kalau tiap orang selalu berusaha meraih hingga sampai pada suatu tujuan, maka pasti orang itu akan berhenti memenuhi kebutuhan-kebutuhannya pada batas-batas yang menjadi kesanggupan pertukaran tenaganya dengan tenaga orang lain; atau sampai pada batas harga (yang sanggup mereka tawar).

Oleh karena itu, maka harga merupakan pengendali yang dibuat secara alami dan bisa menghentikan manusia dari tindakan konsumtif pada batas yang sesuai dengan penghasilannya. Dengan adanya harga itu, manusia kemudian berfikir dan menimbang serta mengukur kebutuhan-kebutuhannya yang kompetitif itu. Dimana kebutuhan-kebutuhan tersebut menuntut agar dipenuhi. Maka, dia kemudian mengambil mana-mana yang dipandangnya urgen dan dia tidak mengambil mana-mana yang dipandangnya kurang urgen. Karena itu, hargalah yang 
memaksa seseorang untuk menganggap cukup dengan terpenuhinya sebagian kebutuhannya, secara parsial, agar pemenuhan terhadap sebagian yang lain tidak lepas dari dirinya. Bagi dia suatu barang sama-sama penting dengan barang yang lain yang telah dipenuhi secara parsial (terpenuhi sebagian saja)

Maka, harga itulah yang juga mengatur distribusi kebutuhan individu dan manfaat/keuntungan yang terbatas pada sejumlah konsumen yang mencari manfaat-manfaat tersebut. Sehingga, ketidakseimbangan penghasilan konsumen itulah yang menjadikan kegiatan konsumsi masing-masing individu tersebut terbatas pada manfaat yang bisa dipenuhi oleh penghasilannya. Dengan demikian konsumsi sebagian barang itu terbatas pada apa yang dipenuhi, sesuai dengan penghasilannya yang akhirnya berlaku secara umum bagi semua orang yang mampu menjangkau batas harga paling minim. Maka kenaikan harga pada sebagian barang dan turun pada sebagian barang yang lain, serta terjangkaunya sebagian barang tersebut oleh upah dalam bentuk uang, dan tidak terjangkaunya sebagian yang lain, maka hargalah yang mengatur distribusi manfaat bagi konsumen.

Sedangkan keberadaan harga sebagai penyeimbang (balance) antara tingkat produksi dan konsumsi, atau sebagai alat perantara antara produsen dan konsumen, itu karena produsen yang memenuhi keinginan-keinginan para konsumen supaya dipuaskan dengan adanya keuntungan yang diperoleh. Sementara bagi produsen jika hasil produksinya tidak diterima oleh para konsumen, pasti dia akan rugi. Cara yang bisa ditempuh oleh produsen agar 
produknya tetap digemari oleh konsumen adalah semata-mata ditentukan oleh harga. Dari harga inilah, dia bisa mengetahui keinginan para konsumen. Apabila konsumen bermaksud membeli barang tertentu, maka harga barang tersebut di pasar akan naik. Karena itu, produksi barang ini terus meningkat agar keinginan para konsumen tersebut bisa terpenuhi. Sebaliknya konsumen tidak mau membeli barang tertentu, tentu harga barang tersebut di pasar akan anjlok. Dengan begitu, jumlah produksi barang tersebut juga akan turun.

Berdasarkan hal ini bahan-bahan mentah yang diperlukan dalam produksi tertentu akan bertambah dengan naiknya harga, dan sebaliknya bahan-bahan mentah yang diperlukan dalam produk-produk tertentu akan turun dengan anjloknya harga. Karena itulah, harga adalah penyeimbang (balance) yang bisa menciptakan keseimbangan antara tingkat produksi dan konsumsi. Dialah yang menjadi alat penghubung antara produsen dengan konsumen. Hal ini berjalan secara otomatis. Dari sinilah, maka harga --menurut pandangan orang-orang Kapitalis-- adalah tiang yang menjadi penyangga ekonomi. Bagi mereka, harga dalam ekonomi ibarat alat pengendali.

Inilah ringkasan sistem ekonomi dalam pandangan Kapitalis. Dan inilah yang mereka sebut dengan Politik Ekonomi (Political Economy). Dengan mengkaji dan membahas secara mendalam, maka akan nampak kebobrokan sistem ekonomi Kapitalis tersebut dari beberapa aspek:

Bagi mereka, ekonomi adalah sesuatu yang membahas tentang kebutuhan-kebutuhan manusia dan sarana-sarana pemenuhannya. Sehingga mereka menjadikan produksi 
barang dan jasa, yang nota bene merupakan sarana pemuas kebutuhan, dengan distribusi barang dan jasa pada kebutuhan-kebutuhan tersebut, sebagai satu pembahasan. Dengan kata lain, mereka menjadikan kebutuhan-kebutuhan dan sarana-sarana pemuasnya merupakan dua hal yang saling menjalin menjadi satu pembahasan. Antara satu dengan lainnya tidak terpisah, malah salah satunya berada di tengah-tengah yang lain. Dengan demikian distribusi barang dan jasa menjadi satu pembahasan dengan produksi barang dan jasa.

Disamping itu, mereka memandang Ekonomi dengan satu pandangan yang meliputi barang-barang produksi (economic goods) dan cara pemerolehannya, tanpa dipisahkan antara keduanya, dan tanpa dibeda-bedakan antara satu dengan yang lainnya. Mereka memandang Ilmu Ekonomi dengan Sistem Ekonomi dengan pandangan yang sama, tanpa membedakan antara satu dengan yang lain. Padahal ada perbedaan antara Sistem Ekonomi dan Ilmu Ekonomi.

\section{Sistem Ekonomi VS IImu Ekonomi}

Sistem Ekonomi menjelaskan tentang distribusi kekayaan dan kepemilikannya, serta bagaimana malakukan transaksi terhadap kekayaan tersebut dan sebagainya. Dengan penjelasan ini berarti mereka mengikuti pandangan hidup tertentu (sistem ekonomi Kapitalis). Oleh karena itu, sistem ekonomi dalam pandangan Islam tentu berbeda dengan sistem ekonomi dalam pandangan Sosialisme maupun komunisme, dan berbeda pula dalam pandangan Kapitalis. Karena, masing-masing mengikuti pandangan hidup ideologi tertentu, yang berbeda dengan IImu Ekonomi. Ilmu Ekonomi 
membahas tentang produksi dan kualitasnya serta bagaimana menentukan dan memperbaiki sarana-sarananya. Hal ini bersifat universal bagi semua bangsa, yang tidak spesifik berdasarkan idiologi tertentu, melainkan seperti layaknya sains yang lain.

Sebagai contoh, adalah pandangan tentang kepemilikan. Kepemilikan dalam Sistem Kapitalis jelas berbeda dengan Sistem Sosialis, dan berbeda pula dengan Sistem Islam. Sedangkan cara memperbaiki produksi, maka hal ini menyangkut suatu realitas (fakta) yang bersifat ilmiah. Hal ini sama bagi semua manusia, dari segi memandangnya, meskipun pemahaman ideologinya bisa berbeda-beda.

Mencampuradukkan antara kebutuhan dengan alat pemuas kebutuhan dalam satu pembahasan, atau antara cara menghasilkan barang-barang produksi dengan cara mendistribusikannya dan menjadikan keduanya sebagai satu kesatuan adalah hal yang keliru. Inilah yang melahirkan kontaminasi dan intervensi dalam pembahasan-pembahasan ekonomi, di kalangan orang Kapitalis. Karena itu, asas pembentukan ekonomi dalam ideologi Kapitalis adalah asas yang salah.

Sedangkan kebutuhan-kebutuhan yang menuntut untuk dipenuhi dan diangap terbatas pada materi adalah juga salah dan bertentangan dengan realitas (fakta) kebutuhan-kebutuhan tersebut. Sebab, ternyata ada kebutuhan moral (ma'nawiyah) dan kebutuhan spiritual (ruhiyah). Dimana kebutuhan tersebut, masing-masing menuntut agar dipenuhi sebagaimana kebutuhan yang bersifat materi. Dan masing-masing membutuhkan barang dan jasa untuk memenuhinya. 
Adapun pandangan para ekonom Kapitalis terhadap kebutuhan dan manfaat, sebagai apa adanya, bukan masalah-masalah yang semestinya harus dijadikan sebagai pijakan oleh masyarakat, adalah pandangan yang mencerminkan bahwa para pakar ekonomi Kapitalis itu melihat manusia yang bersifat materi semata, tanpa kecenderungan-kecenderungan spiritual, pemikiran-pemikiran tentang budi pekerti, dan tujuan-tujuan yang bersifat nonmateri. Mereka tidak pernah memperhatikan masalah-masalah yang semestinya harus dijadikan pijakan oleh masyarakat, seperti ketinggian moral dengan menjadikan sifat-sifat terpuji sebagai dasar buat interaksinya. Termasuk hal-hal yang mendorongnya, seperti ketinggian spiritual, dengan menjadikan kesadaran hubungan dengan Allah sebagai sesuatu yang mengendalikan interaksi-interaksi tersebut dalam rangka memperoleh ridla Allah.

Mereka tidak pernah memperhatikan semua perkara tersebut. Perhatian mereka tiada lain hanya pada materi yang bisa memenuhi kebutuhan-kebutuhan meterial mereka saja. Karena itu, mereka tidak akan melakukan penipuan dalam jual beli kecuali karena ingin mencari untung dalam bisnisnya. Apabila mereka memperoleh keuntungan dengan cara penipuan, maka penipuan tersebut mereka perbolehkan. Mereka juga tidak akan memberi makan fakir miskin karena tunduk pada perintah Allah sebagai pendorong untuk bersedekah. Akan tetapi, mereka melakukannya, karena semata-mata agar fakir miskin tersebut tidak mencuri kekayaan mereka. Kalau kemudian kekayaan dan penghasilan 
mereka bertambah karena membiarkan mereka menderita kelaparan, maka hal itu akan dilakukan.

Begitulah. Perhatian para ekonom Kapitalis terpusat pada manfaat, sebagai sesuatu yang bisa memenuhi kebutuhan material semata. Maka manusia yang memiliki padangan seperti ini pada manusia yang lain serta membangun kehidupan ekonomi dengan berpijak pada pandangan semacam ini, adalah orang yang paling berbahaya bagi masyarakat dan seluruh manusia. Ini dari satu sisi.

Sedangkan dari sisi lain, seluruh harta dan jerih payah yang mereka sebut dengan barang dan jasa itu diperoleh oleh seseorang hanya semata-mata untuk dimanfaatkan serta menjadi alat tukar-menukar yang bisa membentuk hubungan antara satu orang dengan orang lain, maka ketika itu harus dilihat sebagai masalah-masalah yang seharusnya dijadikan pijakan oleh masyarakat tatkala mereka menginginkan harta dan kebutuhan, baik secara global maupun rinci. Karena itu, perhatian terhadap barang-barang produksi dilihat dari segi barang-barang tersebut memuaskan kebutuhan, tanpa memperhatikan masalah-masalah yang semestinya harus dijadikan pijakan oleh masyarakat. Hal itu sama halnya dengan memisahkan barang ekonomi dengan interaksi-interaksi tersebut. Dan ini tentu tidak mungkin. Karena barang-barang produksi tersebut dipergunakan manusia untuk saling tukar, dengan begitu terbentuklah interaksi di antara mereka. Interaksi-interaksi itulah yang membentuk masyarakat. Maka, ketika melihat barang-barang produksi, ia harus dilihat sebagai masalah-masalah yang semestinya harus dijadikan pijakan oleh masyarakat. Karena itu, kita tidak boleh mengklaim barang tersebut bermanfaat, 
semata-mata karena adanya orang yang menginginkannya. Baik barang itu esensinya membahayakan atau tidak; maupun mempengaruhi interaksi-interaksi manusia atau tidak; ataupun yang esensinya diharamkan menurut keyakinan orang atau tidak. Melainkan barang tersebut harus dianggap bermanfaat, sebagai perkara yang semestinya dijadikan pijakan oleh masyarakat.

Berdasarkan hal ini ganja, candu dan sebagainya tidak boleh dianggap sebagai barang yang bermanfaat, atau bahkan menganggapnya sebagai barang-barang produksi, semata-mata karena ada orang yang menginginkannya. Ketika melihat manfaat suatu barang harus melihat pengaruh barang-barang produksi tersebut terhadap hubungan masyarakat. Dengan kata lain, barang tersebut harus dilihat sebagai masalah-masalah yang semestinya dijadikan pijakan oleh masyarakat. Dan tidak boleh dilihat hanya sebatas barang saja.

Konsekuensi adanya pencampuradukan pembahasan tentang pemuasan kebutuhan-kebutuhan tersebut dengan alat-alat pemuasnya, serta konsekuensi pandangan para ekonom terhadap alat-alat pemuas dengan melihatnya hanya sebatas pemuas kebutuhan semata, tidak dengan melihatnya sebagai sesuatu yang lain, menyebabkan pandangan para ekonom tersebut dibangun dengan berpijak pada produksi kekayaan lebih besar daripada distribusinya untuk memenuhi kebutuhan masyarakat. Bahkan pandangan terhadap distribusi tersebut menjadi sebuah pandangan yang tidak utuh. Atas dasar inilah, maka sistem ekonomi Kapitalis itu hanya mengarah kepada satu tujuan, yaitu meningkatkan kekayaan negara secara total. Kemudian berusaha 
memperoleh tingkat produksi hingga setinggi-tingginya. Dan terealisasikannya kemakmuran anggota masyarakat setinggi mungkin sebagai akibat adanya pertambahan pendapatan nasional (national income), dan naiknya produksi suatu negara, yaitu memperoleh kekayaan dengan cara membiarkan mereka sebebas-bebasnya bekerja, untuk memproduksi dan mengumpulkan kekayaan tersebut.

Karena itu, ekonomi --dalam pandangan orang Kapitalis-bukan dibentuk dalam rangka memenuhi kebutuhan-kebutuhan individu serta terpenuhinya kebutuhan masing-masing individu secara menyeluruh, melainkan terfokus pada barang-barang yang akan memenuhi kebutuhan mereka. Dengan kata lain, terpenuhinya kebutuhan-kebutuhan secara kolektif, dengan naiknya produksi dan bertambahnya pendapatan nasional (national income) di suatu negara. Dengan cara tersebut, maka distribusi pendapatan dilakukan dengan cara kebebasan kepemilikan dan kebebasan bekerja bagi anggota masyarakat, yaitu anggota masyarakat dibiarkan sebebas-bebasnya untuk memperoleh kekayaan apa saja yang mampu mereka peroleh, sesuai dengan faktor-faktor produksinya masing-masing. Baik pemenuhan tersebut dapat dipenuhi untuk untuk seluruh anggota masyarakat, atau terjadi pada sebagian orang, sedangkan yang lain tidak. Inilah Politik Ekonomi (Political Economy), atau Ekonomi Kapitalis. Ini jelas-jelas keliru dan bertentangan dengan realitas, serta tidak menyebabkan naiknya taraf kehidupan individu secara menyeluruh. Begitu pula, tidak pernah menghasilkan kemakmuran bagi setiap individu rakyat. 
Kesalahannya terletak pada, bahwa kebutuhan-kebutuhan yang menuntut pemenuhan tersebut adalah kebutuhan-kebutuhan individu sebagai sebagai kebutuhan manusia (misalnya kebutuhan si Muhammad, si Shalih, si Hasan, dan lain-lain), bukan kebutuhan-kebutuhan segenap manusia, umat, ataupun bangsa. Sedangkan yang berupaya memenuhi kebutuhan-kebutuhannya adalah individu. Baik pemenuhannya untuk dirinya secara langsung, seperti makan atau pemenuhannya untuk dirinya karena terpenuhi secara kolektif seperti perlindungan terhadap umat.

Dengan demikian, masalah ekonomi sebenarnya hanya bertumpu pada distribusi alat-alat pemuas tersebut kepada individu; yaitu pendistribusian barang dan jasa kepada individu umat atau bangsa. Bukan bertumpu pada kebutuhan-kebutuhan yang dituntut oleh umat atau bangsa secara total, tanpa melihat masing-masing individunya. Dengan kata lain, masalahnya adalah kemiskinan yang menimpa individu. Bukan kemiskinan yang menimpa negara. Sehingga membahas sistem ekonomi adalah semata-mata membahas tentang bagaimana kebutuhan-kebutuhan pokok bagi setiap individu itu bisa terpenuhi. Bukan membahas tentang bagaimana agar barang-barang ekonomi tersebut bisa diproduksi.

Dari sinilah, maka mengkaji faktor-faktor yang mempengaruhi laju produksi nasional itu tidak lagi menjadi pembahasan yang membahas tentang pemenuhan seluruh kebutuhan pokok individu, secara pribadi-pribadi dengan cara menyeluruh. Akan tetapi, tema pembahasannya malah mengarah kepada pembahasan tentang 
kebutuhan-kebutuhan pokok (basic needs) manusia, dari segi manusianya (dengan sejumlah kebutuhan yang cenderung meningkat), serta pembahasan tentang distribusi kekayaan bagi anggota masyarakat, untuk menjamin terpenuhinya seluruh kebutuhan pokok (basic needs) mereka, dimana hal itu menjadi suatu keharusan dan menduduki posisi utama.

Padahal dengan terpecahkannya masalah kemiskinan negara itu tetap tidak bisa memecahkan masalah kemiskinan individu-individu secara pribadi-pribadi. Sebaliknya dengan terpecahkannya masalah kemiskinan individu dan terdistribusikannya kekayaan negara itulah yang justru akan mendorong rakyat serta warga suatu negara untuk bekerja meningkatkan pendapatan (income) perkapita masyarakat. Sedangkan pembahasan yang membahas faktor-faktor yang bisa mempengaruhi laju produksi nasional dan income perkapita masyarakat itu, sebenarnya pembahasannya dibahas dalam ilmu ekonomi. Artinya, pembahasan tentang barang ekonomi (ekonomic goods) dan penambahan kuantitasnya, bukan membahas tentang pemenuhan kebutuhan-kebutuhan yang diatur oleh sistem ekonomi.

Sedangkan tentang kelangkaan barang dan jasa yang bersifat nisbi (relatif) yang dianggap sebagai masalah ekonomi yang senantiasa dihadapi oleh masyarakat, termasuk klaim tentang banyaknya kebutuhan sedangkan alat pemuasnya terbatas, dengan kata lain ketidakmampuan barang dan jasa untuk memenuhi semua kebutuhan manusia dengan pemenuhan secara menyeluruh, bahkan sebagai masalah utama ekonomi, adalah salah dan bertentangan dengan kenyataan. Hal itu, karena kebutuhan-kebutuhan yang harus dipenuhi secara pasti adalah 
kebutuhan-kebutuhan primer (basic needs) individu, dalam kapasitasnya sebagai manusia, bukan kebutuhan skunder ataupun tersier (lux). Meskipun, kebutuhan tersier (lux) tersebut juga bisa saja diupayakan dan dipenuhi.

Karena itu, sebenarnya kebutuhan-kebutuhan primer (basic needs) tersebut terbatas kuantitasnya, dimana kekayaan dan jerih payah (tenaga) yang mereka sebut dengan barang dan jasa yang ada di dunia itu sebenarnya cukup untuk memenuhi kebutuhan-kebutuhan primer (basic needs) tersebut. Dimana seluruh kebutuhan primer (basic needs) tersebut bisa saja dipenuhi dengan pemenuhan secara menyeluruh oleh tiap-tiap konsumen. Sehingga tidak akan ada masalah dalam pemenuhan kebutuhan-kebutuhan primer (basic needs) tersebut, lebih-lebih dengan mengklaimnya sebagai masalah ekonomi yang senantiasa akan dihadapi oleh masyarakat.

Karena masalah ekonomi itu sebenarnya hanya terletak pada masalah pendistribusian kekayaan dan tenaga tersebut kepada tiap individu, dalam rangka memenuhi kebutuhan-kebutuhan primer (basic needs) mereka dengan pemenuhan secara menyeluruh, serta membantu mereka berusaha untuk memenuhi kebutuhan-kebutuhan skunder hingga kebutuhan-kebutuhan tersier (lux) mereka.

Sedangkan masalah bertambahnya kebutuhan-kebutuhan yang silih berganti itu, sebenarnya tidak ada hubungannya dengan bertambahnya kebutuhan-kebutuhan primer (basic needs) tersebut. Karena kebutuhan-kebutuhan primer (basic needs) manusia, dari segi manusianya (yaitu bisa memenuhi sandang, papan dan pangan) itu tidak akan pernah bertambah (bersifat statis). Akan tetapi yang bertambah dan 
terus meningkat adalah kebutuhan skunder atau tersier (misalnya, sudah bisa makan, ingin meningkatkan kualitas makanannya, atau bisa me nyandang, ingin meningkatkan kualitas sandangnya, dan sudah bisa mengusahakan papan, masih ingin meningkatkan kualitas papannya --pent.). Maka, bertambahnya kebutuhan-kebutuhan yang ada terkait dengan majunya kehidupan materi manusia, sebenarnya hanya terkait dengan kebutuhan-kebutuhan skunder atau tersier (lux), dan bukan basic needs -nya. Dimana kebutuhan-kebutuhan skunder atau tersier tersebut memang bisa diusahakan untuk dipenuhi, sekalipun kalau tidak dipenuhi juga tidak akan menimbulkan masalah. Justru yang menimbulkan masalah adalah apabila kebutuhan-kebutuhan primer (basic needs) tersebut tidak terpenuhi.

Hanya saja bertambahnya kebutuhan-kebutuhan skunder atau tersier (lux) itu adalah masalah lain, yang berhubungan dengan sejumlah komunitas yang hidup pada suatu daerah tertentu, dan tidak berhubungan dengan salah satu anggota komunitas daerah tersebut. Masalah inilah yang secara alami mendorong manusia untuk memenuhi kebutuhannya. Sehingga, dia terdorong oleh dorongan yang muncul dari bertambahnya kebutuhan-kebutuhan skunder atau tersier tersebut untuk berusaha menambah kauntitas alat-alat pemuas (yang dimiliki)-nya. Dimana, adakalanya dengan melakukan ekploitasi atau ekplorasi kekayaan alam yang ada di negaranya, atau dengan cara bekerja di negara lain, atau perluasan usaha dan melakukan join di negara lain.

Dan masalah ini tentu berbeda dengan masalah pemenuhan kebutuhan-kebutuhan primer (basic needs) tiap anggota masyarakat tersebut secara menyeluruh. Karena 
masalah pendistribusian kekayaan kepada individu secara pribadi-pribadi untuk memenuhi seluruh kebutuhan primer (basic needs) mereka secara menyeluruh, serta membantu tiap individu untuk memenuhi kebutuhan-kebutuhan skunder atau tersiernya, itu adalah masalah yang berkaitan dengan pandangan hidup tertentu, dan hal itu bersifat khas bagi bangsa-bangsa tertentu, atau ideologi tertentu.

Dimana, hal itu berbeda dengan masalah peningkatan income perkapita masyarakat dengan meningkatkan GNP-nya. Karena masalah tersebut menyangkut realitas negara yang bersifat riil, dari segi pengetahuan untuk menambah kuantitas kekayaan tersebut, baik dengan cara ekploitasi dan ekplorasi, atau imigrasi, atau perluasan usaha, ataupun dengan join. Dimana, masalah tersebut disesuaikan dengan realitas yang ada dan bisa dilaksanakan oleh setiap manusia (bersifat universal), dan umum yang tidak menyangkut pandangan hidup tertentu, serta tidak dispesifikasikan bagi bangsa dan ideologi tertentu.

Karena itu, kebijakan ekonomi yang dipergunakan semestinya adalah kebijakan yang bisa menjamin pendistribusian kekayaan negara, baik kekayaan di dalam maupun di luar negeri, kepada seluruh anggota masyarakat secara pribadi-pribadi, dari segi terjaminnya pemenuhan seluruh kebutuhan primer (basic needs) semua anggota masyarakat secara pribadi-pribadi, dengan pemenuhan secara menyeluruh. Disamping terjaminnya kemungkinan tiap anggota masyarakat untuk memenuhi kebutuhan-kebutuhan skunder atau tersier (lux) mereka.

Sedangkan untuk menaikkan tingkat produksi itu membutuhkan pembahasan ilmiah. Kalaupun pembahasan 
tersebut kemudian dibahas dalam sistem ekonomi, itu tentu tidak akan menyelesaikan masalah ekonomi, yaitu terpenuhinya seluruh kebutuhan individu secara pribadi-pribadi dengan cara menyeluruh. Sebab, bertambah tingkat produksi tersebut akan menyebabkan meningkatnya tingkat kekayaan negara, dan tidak menyebabkan terpenuhinya seluruh kebutuhan primer (basic needs) semua individu dengan menyeluruh. Sebab, kadang-kadang negara tersebut kaya, dengan tingkat produksi nasionalnya (yang tinggi), semisal Irak dan Saudi, akan tetapi kebutuhan-kebutuhan primer (basic needs) mayoritas anggota masyarakat di sana, tidak terpenuhi dengan pemenuhan secara menyeluruh.

Oleh karena itu, bertambahnya tingkat produksi nasional tersebut tidak akan menyelesaikan masalah utama, yang harus segera dipecahkan sebelum yang lainnya, yaitu terpenuhinya seluruh kebutuhan primer (basic needs) semua anggota masyarakat secara pribadi-pribadi, dengan cara menyeluruh, kemudian membantu mereka untuk memenuhi kebutuhan-kebutuhan skunder atau tersier (lux) mereka. Karenanya, kemiskinan absolut (absolut proverty) dan kemiskinan struktural (stuctural proverty), yang menuntut harus dipecahkan itu adalah kemiskinan karena ketidakterpenuhinya kebutuhan-kebutuhan primer (basic needs) manusia dalam kapasitasnya sebagai manusia, bukan karena ketidakterpenuhinya kebutuhan-kebutuhan yang terus meningkat mengikuti perkembangan materi.

Sedangkan kemiskinan absolut (absolut proverty) dan kemiskinan struktural (stuctural proverty), yang menuntut harus dipecahkan itu adalah kemiskinan masing-masing 
anggota masyarakat secara pribadi-pribadi, bukan absolut dan stuctural proverty suatu negara. Kemiskinan tiap orang dengan konsepsi semacam ini, itu tidak akan bisa terpecahkan dengan menambah jumlah produksi nasional. Akan tetapi, hanya bisa terpecahkan dengan cara mendistribusikan kekayaan kepada seluruh individu secara pribadi-pribadi, dari segi terpenuhinya seluruh kebutuhan primer (basic needs) tiap individu secara menyeluruh, kemudian dibantu untuk memenuhi kebutuhan-kebutuhan skunder atau primer mereka.

Adapun terhadap nilai, sistem ekonomi Kapitalis menganggap nilai tersebut bersifat nisbi (relatif), bukan hakiki (paten). Maka, menurut mereka, nilai itu adalah nilai menurut anggapan (i'tibariyah), artinya tinggal siapa yang menilai dan dengan apa dia dibandingkan. Karena itu, nilai satu hasta kain yang terbuat dari wool adalah batas akhir kemanfaatan (kegunaan) kain tersebut pada saat kain tersebut bisa diperoleh di pasar. Dimana nilainya bisa diukur dengan barang dan jasa yang bisa diperoleh oleh kain tersebut. Sehingga nilai tersebut akan berubah menjadi harga, apabila sesuatu yang dipergunakan --sebagai ukuran (standar)-- untuk memperoleh kain tersebut adalah uang.

Dua nilai ini, menurut mereka, adalah dua hal yang harus dibedakan. Dimana masing-masing disebut dengan sebutan yang berbeda dengan yang lain. Yang satu disebut dengan sebutan nilai guna (utility value) dan yang lain disebut dengan sebutan nilai tukar (exchange value). Dan makna nilai, dengan batasan semacam ini adalah sesuatu yang salah. Karena nilai barang apapun, sebenarnya semata-mata ditentukan oleh kemanfaatan (kegunaan)-nya, dengan memperhatikan faktor 
kelangkaannya. Sehingga pandangan yang hakiki (paten) terhadap barang apapun, adalah pandangan terhadap kemanfaatan (kegunaan) dengan memperhatikan faktor kelangkaannya. Baik, yang dimiliki oleh manusia sejak asal semisal hasil buruan, atau karena pertukaran semisal hasil penjualan, maupun barang tersebut terkait dengan orang lain atau terkait dengan benda.

Karena itu, nilai hakikatnya adalah nama bagi sebutan tertentu yang bersifat paten dan personal; bukan nama benda yang bersifat i'tibariyah dan tidak layak diberlakukan terhadap sesuatu yang lain. Maka, nilai itu hakikatnya adalah sesuatu yang paten, bukan merupakan sesuatu yang nisbi (relatif). Karena itu, pandangan para ekonom tersebut terhadap nilai ini adalah pandangan yang salah dari asasnya.

Sedangkan apa yang mereka sebut dengan nilai batas (marginal value), yaitu perkiraan bagi tingkat produksi yang disesuaikan dengan tingkat kecenderungan yang terkait dengan penjualan barang-barang, maka nilai barang itu akan ditentukan berdasarkan batas paling rendah, sehingga produksinya tetap terus berjalan dengan pijakan yang bisa dijamin. Dimana, nilai batas (marginal value) itu hakikatnya bukan nilai barang, bahkan nilai tersebut juga tidak ada kaitannya dengan harga barang. Karena nilai barang itu semata-mata ditentukan oleh perkiraan guna (utility) barang tersebut dengan memperhatikan faktor kelangkaannya. Dimana setelah itu, turunnya harga barang tersebut tidak akan mengurangi nilainya, sebagaimana naiknya harga barang tersebut, setelah itu, juga tidak akan menambah nilainya. Sebab nilai barang tersebut sebanarnya bisa diukur, ketika diperkirakan. Karena itu, teori batas (marginal theory) ini 
hakikatnya adalah teori tentang harga, bukan teori tentang nilai.

Dalam hal ini ada perbedaan antara harga dengan nilai, bahkan menurut kalangan ekonom Kapitalis sekalipun. Dimana harga perkiraannya ditentukan berdasarkan banyaknya permintaan dan sedikitnya penawaran, atau banyaknya penawaran dan sedikitnya permintaan secara bersamaan. Dimana harga itu merupakan sesuatu yang terkait dengan bertambahnya produksi dan bukan terkait dengan pendistribusiannya. Sedangkan nilai, perkiraannya ditentukan oleh manfaat (utility) yang terdapat pada barang ketika barang tersebut diukur, dengan memperhatikan faktor kelangkaannya, tanpa memasukkannya sebagai bagian dari perkiraan tersebut. Dimana ia juga tidak dipengaruhi sama sekali oleh besar-kecilnya penawaran dan permintaan.

Karena itu pembahasan tentang nilai tersebut, dari segi asasnya, adalah salah semua. Maka, pembahasan yang dibangun dengan asas yang salah tersebut, dari segi serpian (furu'), adalah salah. Hanya saja, apabila nilai tersebut kegunaan (utility)-nya diperkirakan dengan kegunaan barang atau jasa tertentu, maka itu merupakan perkiraan yang tepat. Dimana perkiraan tersebut merupakan perkiraan yang mendekati suatu kepastian dalam jangka pendek. Dan apabila nilai tersebut kegunaan (utility)-nya diperkirakan dengan harga, maka itu merupakan perkiraan yang bersifat i'tibariyah, bukan hakiki (paten) lagi. Dimana pada saat itu, nilai tersebut akan menjadi berubah-ubah setiap saat mengikuti kecenderungan pasar. Dan pada saat itu, keberadaannya sebagai nilai akan gugur, sehingga realitas nilai tersebut tidak layak lagi disebut dengan sebutan nilai, 
melainkan telah berubah menjadi alat yang di dalamnya terdapat nilai uang dengan mengikuti pasar, bukan mengikuti kegunaan-kegunaan (utility) yang ada di dalamnya.

Para ahli ekonomi Kapitalis mengatakan, bahwa kegunaan (utility) itu adalah hasil jerih payah yang telah dicurahkan oleh manusia. Maka, apabila upah --yang diberikan-- tidak sebanding dengan kerjanya, tentu tingkat produksi nasional akan menurun. Karena itulah, maka mereka berkesimpulan bahwa cara (metode) yang paling ideal untuk mendistribusikan kekayaan tersebut kepada anggota masyarakat adalah cara yang harus bisa menjamin tercapainya tingkat produksi nasional yang setinggi-tingginya. Pernyataan ini juga salah sekali.

Karena kenyataannya, kekayaan yang telah diciptakan oleh Allah di alam inilah yang sebenarnya merupakan asas (dasar) kegunaan (utility) barang-barang tersebut. Sedangkan sejumlah biaya (cost) yang telah dikorbankan untuk menambah kegunaan kekayaan tersebut, atau mengupayakan kegunaan kekayaan tersebut dengan disertai tindakan tertentu itulah yang sebenarnya telah menjadikan kekayaan tersebut secara pasti menghasilkan kegunaan (utility) tertentu. Sehingga, mengklaim kegunaan (utility) tersebut sebagai semata-mata hasil jerih payah tertentu adalah salah, yang bertentangan dengan kenyataan dan mengabaikan barang yang berharga serta biaya-biaya (cost) yang telah dikorbankan. Dan kadang-kadang biaya (cost) tersebut sebagai ganti barang yang berharga, dan bukannya sebagai ganti suatu pekerjaan. Karena itu, kegunaan (utility) tersebut bisa jadi merupakan hasil jerih payah manusia, dan bisa jadi merupakan hasil adanya benda yang berharga. Dan bisa jadi 
merupakan hasil kedua-duanya secara bersamaan. Dan bukannya semata-mata hasil jerih payah manusia.

Sedangkan merosotnya tingkat produksi nasional itu, sebenarnya bukan merupakan akibat dari ketidakseimbangan antara upah dengan kerja saja. Sebab, kadang terjadi memang karena sebab tersebut. Dan kadang terjadi karena habisnya seluruh kekayaan negara. Dan kadang terjadi akibat peperangan. Juga kadang terjadi akibat yang lain.

Merosotnya produksi nasional Inggris dan Prancis setelah Perang Dunia II bukan karena ketidakseimbangan antara tingkat upah dengan kerja, melainkan karena menyusutnya daerah-daerah jajahannya yang kaya dari cengkraman masing-masing negara tersebut, juga karena mereka berperang habis-habisan. Sedangkan merosotnya produksi nasional Amerika Serikat pada saat terjadinya Perang Dunia II bukan karena ketidakseimbangan antara tingkat upah dengan kerja, melainkan karena Amerika berperang habis-habisan melawan Jerman. Sedangkan merosotnya produksi nasional dunia Islam saat ini, bukan karena ketidakseimbangan antara upah dengan kerja, melainkan karena merosotnya potensi berfikir yang menjangkit seluruh umat Islam.

Karena itu, ketidakseimbangan antara upah dengan kerja bukan merupakan sebab satu-satunya merosotnya tingkat produksi nasional, sehingga membawa konsekuensi bahwa cara yang ideal untuk mendistribusikan kekayaan negara adalah cara yang bisa menjamin meningkatnya tingkat produksi nasional. Begitu pula tercapainya tingkat produksi nasional yang setinggi-tingginya itu, juga tidak ada kaitannya dengan pendistribusian devisa kepada individu. 
Para ahli ekonomi Barat berpendapat, bahwa harga adalah pendorong laju produksi. Sebab yang mendorong manusia untuk mencurahkan tenaganya adalah terpenuhinya kebutuhan manusia secara materi. Ini adalah pernyataan yang bertentangan dengan kenyataan, dan jelas tidak tepat. Sebab banyak tenaga yang telah dikeluarkan oleh manusia adalah untuk memenuhi kebutuhan moralitas, seperti bangga, atau untuk memenuhi kebutuhan spiritual seperti memperoleh pahala dari Allah atau untuk mewujudkan sifat akhlak, seperti menunaikan janji. Karena kebutuhan manusia kadang-kadang bersifat materi, seperti ingin memperoleh keuntungan materi, atau kadang-kadang bersifat spiritual, seperti pengkultusan, atau kadang-kadang bersifat emosional, seperti pujian. Karena itu, membatasi kebutuhan hanya sebatas kebutuhan materi itu tidak tepat. Karena manusia, kadang-kadang mengorbankan sejumlah hartanya untuk memenuhi kebutuhan spiritual, atau kebutuhan moralitas yang lebih besar jumlahnya ketimbang yang dia korbankan untuk memenuhi kebutuhan-kebutuhan materinya.

Karena itu, bukan harga itulah yang semata-mata bisa mendorong tingkat produksi. Karena kadang-kadang harga, dan kadang-kadang yang lain. Tidakkah anda lihat, bahwa seorang pemecah batu kadang-kadang mengkhususkan dirinya bekerja berbulan-bulan untuk memecah batu untuk pembangunan masjid? Dan seorang produsen kadang-kadang menghasilkan produknya berhari-hari agar bisa mendistribusikan produk-produknya kepada para fakir-miskin? Ada umat yang kadang-kadang mengkhususkan tenaganya untuk menggali parit-parit dan mempersiapkan 
perbekalan agar bisa mempertahakan negerinya? Dan apakah kegiatan produksi semacam ini didorong oleh harga? Padahal, jelas pemenuhan secara materi itu sendiri tidak dibatasi oleh harga. Karena kadang-kadang dengan materi yang lain, atau dengan jasa. Sehingga, menjadikan harga sebagai satu-satunya yang mendorong laju produksi itu adalah tidak benar.

Bahkan yang sangat ganjil adalah apa yang dinyatakan oleh sistem ekonomi Kapitalis, yaitu dijadikannya harga sebagai penentu satu-satunya bagi pendistribusian kekayaan kepada anggota masyarakat. Mereka mengatakan, bahwa hargalah yang menjadi pengendali yang menjadikan manusia, ketika mengumpulkan dan mengkonsumsi barang bergantung pada batas yang mengikuti barang-barangnya. Dan hargalah yang menjadikan konsumsi tiap orang sebatas apa yang bisa dipenuhi oleh barang-barangnya. Dengan demikian, naiknya harga pada beberapa barang dan menurunnya pada beberapa barang yang lain, serta kemampuan uang pada sebagian barang dan ketidakmampuannya pada sebagian yang lain, maka menjadikan harga itu sebagai penentu distribusi kekayaan kepada para konsumen. Dimana, bagian tiap orang untuk mendapatkan kekayaan negara tersebut tidak diukur berdasarkan standar kebutuhan-kebutuhan primer (basic needs)-nya, melaikan disesuaikan dengan nilai jasa-jasa yang telah diinvestasikan untuk menghasilkan sejumlah barang dan jasa. Artinya, diukur berdasarkan tanah atau harta yang berhasil dikumpulkan, atau diukur berdasarkan kerja atau pengaturan proyek-proyek yang telah dilakukan. 
Dengan kaidah semacam ini, yaitu menjadikan harga sebagai penentu distribusi, maka sistem ekonomi Kapitalis itu telah mengukuhkan bahwa orang yang berhak hidup hanyalah orang yang mampu memberikan andil (saham) untuk menghasilkan barang dan jasa. Sedangkan orang yang tidak mampu melakukannya, karena orang tersebut diciptakan dalam kondisi lemah, atau ada kelemahan yang menimpa dirinya, maka orang tersebut tidak layak hidup. Karena dia tidak berhak memperoleh kekayaan negara untuk memenuhi kebutuhan-kebutuhannya. Sebaliknya, yang layak memperoleh kehormatan, kekuasaan dan menguasai orang lain dengan hartanya adalah orang yang mampu melakukannya. Karena orang tersebut diciptakan dalam keadaan kuat, baik tubuh maupun akalnya. Dimana orang tersebut lebih kuat daripada yang lain untuk mengumpulkan harta dengan cara apapun.

Begitu pula kekayaannya akan bertambah melebihi yang lain, apabila orang yang bersangkutan kecenderungan materinya kuat. Dan menurunlah kekayaannya daripada yang lain, apabila orang yang bersangkutan kecenderungan spiritualnya dan keterikatannya kepada sifat-sifat moral lebih kuat. Karena orang yang bersangkutan dalam mengupayakan materi terikat dengan apa yang diwajibkan kepadanya oleh kendali-kendali spiritual atau moral yang pemikiran-pemikirannya dia genggam. Maka, cara Kapitalis semacam ini, tentu akan menjauhkan unsur spiritual dan akhlak dari kehidupan serta menjadikan hidupnya yaitu kehidupan materi, sebagai asas perjuangan materinya dalam rangka mendapatkan alat-alat pemuas kebutuhan-kebutuhan yang bersifat materi tersebut. Inilah kenyataan yang terjadi di 
negara-negara yang menganut serta menerapkan sistem Kapitalis tersebut.

Di negara-negara yang sistem ekonominya menganut sistem Kapitalis, jelas-jelas nampak adanya cengkraman kaum borjuis (pemilik modal). Para produsen benar-benar menguasai kelompok konsumen. Dimana hanya segelintir orang, seperti para pemilik perseroan-perseroan raksasa, semisal perusahaan perminyakan, mobil serta industri-industri berat dan sebagainya yang menguasai dan mengendalikan mayoritas konsumen, termasuk yang mengendalikan harga barang bagi para konsumen tersebut. Dan inilah yang mengharuskan adanya upaya penambalan sistem ekonomi tersebut. Kemudian mereka memberikan hak kepada negara untuk ikut andil dalam menentukan harga (bentuknya semacam harga patokan semen, pent.) dalam kondisi-kondisi tertentu, yang tujuannya untuk melindungi perekonomian masyarakat dan melindungi para konsumen, serta menekan jumlah konsumsi pada bebarapa barang, termasuk menentukan batas kekuasaan para kongkomerat. Mereka juga telah menjadikan proyek-proyek umum yang dikendalikan oleh negara itu berada dalam pengaturan produksi.

Hanya saja, penambalan-penambalan semacam ini, sekalipun kenyataan justru bertentangan dengan asas sistem ekonomi tersebut --yaitu kebebasan ekonomi-- nyatanya terjadi dalam beberapa kondisi dan situasi tertentu. Padahal kebanyakan ahli ekonomi Kapitalis, seperti mazhab Individualisme --yang menganut Laissez Faire -- tidak pernah menyatakannya justru malah menolaknya. Mereka mengatakan, bahwa struktur harga saja sudah cukup untuk 
menjamin terwujudnya keserasian antara kepentingan para produsen dengan kepentingan para konsumen. Yang tidak perlu lagi campur tangan sedikitpun dari pihak pemerintah.

Hanya saja, penambalan-penambalan yang dinyatakan oleh para penganjur ini adalah semata-mata terjadi dalam situasi dan kondisi tertentu. Sekalipun demikian, ternyata setelah sampai pada kondisi dan situasi semacam ini, tetap saja distribusi kekayaan kepada individu belum bisa mewujudkan terpenuhinya seluruh kebutuhan individu dengan pemenuhan secara menyeluruh. Dengan demikian, maka kejelekan distribusi yang dilaksanakan dengan mempergunakan asas kebebasan kepemilikan serta menjadikan harga sebagai struktur distribusi kekayaan satu-satunya, itu tetap saja mencengkram tiap masyarakat yang menerapkan sistem ekonomi Kapitalis.

Adapun apa yang terjadi di Amerika, dimana kekayaan yang ada bisa diperoleh oleh tiap orang Amerika untuk memenuhi seluruh kebutuhan primer (basic needs)-nya dengan pemenuhan secara menyeluruh dan terpenuhinya beberapa kebutuhan mereka yang lain, itu adalah karena melimpahnya kekayaan negara tersebut sampai pada batas yang memungkinkan tiap individu untuk menikmati terpenuhinya seluruh kebutuhan primer dan beberapa kebutuhan skunder atau kebutuhan tersier (lux) mereka, bukan karena menjadikan bagian tiap orang seimbang dengan nilai jasa yang telah mereka investasikan dalam berproduksi.

Sedangkan struktur hargalah yang menjadi pengendali distribusi itu benar-benar telah menjadikan konglomerasi di Barat keluar ke luar negeri untuk mencari pasar sehingga bisa 
memperoleh barang-barang yang berharga dan pasar untuk menjual hasil industri (produksi)-nya. Karena itu terjadinya kolonialisasi, daerah-daerah jajahan dan perang ekonomi itu semata-mata akibat dari persekutuan para konglomerat raksasa tersebut.

Dan dengan menjadikan hargalah sebagai pengendali terdistribusikannya kekayaan itu juga mengakibatkan terjadinya pengumpulan kekayaan-kekayaan dunia dengan berpijak kepada asas ini, kemudian diberikan kepada kaum borjuis (baca: para kapitalis) tersebut. Semuanya itu adalah akibat kebobrokan kaidah yang ditetapkan oleh sistem ekonomi Kapitalis tersebut.

\section{Sistem Ekonomi Sosialis}

Inilah pandangan menurut sistem ekonomi Kapitalis. Sedangkan menurut pandangan ekonomi Sosialis, termasuk di antaranya Komunisme, sebenarnya bertolak belakang dengan sistem ekonomi Kapitalis. Pandangan-pandangan Sosialis tersebut benar-benar nampak dominan pada abad ke-19. Dimana orang-orang Sosialis telah memerangi mati-matian pandangan-pandangan mazhab Liberalisme, atau sistem ekonomi Kapitalis. Munculnya Sosialisme dengan bentuk yang kuat itu adalah akibat kedzaliman yang diderita oleh masyarakat karena sistem ekonomi Kapitalis serta beberapa kekeliruan yang terjadi di dalamnya.

Dengan memaparkan mazhab Sosialism ini, maka nampaklah bahwa mazhab ini mengikuti tiga prinsip yang berbeda dengan mazhab-mazhab ekonomi sebelumnya:

Pertama, mewujudkan kesamaan (equality) secara riil. 
Kedua, menghapus kepemilikan individu (private propherty) sama sekali atau sebagian saja.

Ketiga, mengatur produksi dan distribusi secara kolektif.

Meskipun dalam ketiga hal ini telah sepakat, akan tetapi masih ada perbedaan yang tajam antara satu dengan yang lain, dalam beberapa hal. Dan yang terpenting adalah:

Pertama, bahwa mazhab Sosialism, dari segi bentuk kesamaan secara riil yang ingin mereka realisasikan itu tidak sama. Ada satu kelompok yang menyebut dengan "Kesamaan Hisabiyah ". Sedangkan yang dimaksud dengan "Kesamaan Hisabiyah " adalah kesamaan dalam segala hal yang bisa dimanfaatkan. Dimana, tiap orang akan diberi sesuatu yang sama seperti yang diberikan kepada orang lain. Sedangkan kelompok lain menyebut dengan "Kesamaan Syuyu'iyah ". Adapun yang dimaksud dengan "Kesamaan Syuyu'iyah " adalah, bahwa pembagian kerja harus dilakukan menurut kemampuan tiap orang sementara pembagian hasilnya harus dilakukan menurut kebutuhan masing-masing. Bagi mereka, kesamaan tersebut akan terwujud apabila kaidah ini diterapkan: "Masing-masing (akan diberi pekerjaan) sesuai dengan kemampuannya (maksudnya, sesuai dengan kemampuan usaha yang bisa dia lakukan) dan masing-masing mendapatkan sesuatu sesuai dengan kebutuhannya (maksudnya, hasil yang dibagikan)." Sebagian yang lain menyatakan kesamaan dalam masalah faktor-faktor produksi, dilihat dari segi bahwa benda-benda tersebut kenyataannya tidak cukup untuk memenuhi kebutuhan-kebutuhan tiap orang. Sehingga kaidah pembagian ini harus diikuti: "Masing-masing sesuai dengan kemampuannya atau kesanggupannya, dan masing-masing sesuai dengan 
aktivitasnya." Kesamaan tersebut benar-benar akan terwujud kalau tiap orang dibekali dengan faktor-faktor produksi yang sama dengan orang lain.

Kedua, mazhab-mazhab Sosialism, dari segi standar penghapusan kepemilikan individu (private propherty), juga berbeda. Ada yang menyatakan bahwa private propherty harus dihapus secara mutlak. Mazhab inilah yang disebut dengan mazhab Komunism. Sedangkan kelompok lain berpendapat bahwa private propherty yang berhubungan dengan barang-barang produktif, atau yang disebut dengan sebutan capital, itulah yang harus dihapus, semisal tanah, industri, rel, jalan dan sebagainya. Artinya dilarang memiliki setiap barang yang bisa menghasilkan sesuatu yang lain (baca: faktor-faktor produksi). Sehingga, tidak boleh mempunyai rumah untuk disewakan, termasuk tidak boleh mempunyai pabrik, tanah dan sebagainya. Akan tetapi mereka mentolelir private propherty terhadap barang-barang konsumtif. Sehingga, mereka boleh memiliki apa saja yang bisa mereka konsumsi. Maka, mereka boleh mempunyai rumah untuk tempat tinggal saja dan memiliki apa saja yang bisa dihasilkan oleh tanah dan industri. Inilah mazhab Sosialism Kapitalis. Sementara mazhab yang lain tidak mengatakan tentang penghapusan kepemilikan khusus, kecuali yang berhubungan dengan tanah pertanian, bukan yang lain. Mazhab tersebut disebut dengan sebutan mazhab Sosialism Pertanian . Ada juga yang mengatakan: "Anda harus mengkaji setiap kondisi yang di dalamnya terdapat kemaslahatan umum yang menganjurkan perubahan milik khusus menjadi milik umum, termasuk pembatasan para pemilik kepemilikan khusus pada kebanyakan penduduk, agar 
penguasa membuat batasan yang tertinggi untuk persewaan dan batasan terendah untuk upah. Dan para pekerja dibiarkan memperoleh capital dan sebagainya." Inilah yang kemudian disebut dengan mazhab Sosialism Negara (State Sosialism).

Ketiga, mazhab-mazhab Sosialism berbeda-beda dalam menentukan sarana yang dikatakan sebagai alat untuk mewujudkan tujuan-tujuan mereka. Mazhab Naqabiyah Tsauriyah mementingkan kebebasan para pekerja terhadap apa yang disebutnya dengan kerja langsung, yaitu tenaga para pekerja itu sendiri, semisal memperbanyak kerja, merusak alat-alat, menyebarkan ide kerja secara umum di kalangan pekerja, serta persiapan untuk merealisasikannya sampai pada suatu saat yang memungkinkan mereka untuk mewujudkan tuntutan-tuntutan mereka. Sehingga gerakan ekonomi tersebut menyebar, dan mengalirlah sistem ekonomi seperti sekarang ini.

Sedangkan mazhab Sosialis Marxisme, menyakini hukum evolusi sosial, termasuk menyakini bahwa hukum itu saja sudah cukup untuk menghancurkan sistem yang ada, serta mengganti sistem tersebut dengan sistem lain yang dibangun dengan asas Sosialism.

Adapun sarana para penganut mazhab Sosialism Negara (State Sosialism) dalam menerapkan pemikiran-pemikiran mereka adalah undang-undang. Karena dengan adanya pembuatan undang-undang tersebut, akan ada sesuatu yang bisa menjaga terpeliharanya kemaslahatan umum serta perbaikan kondisi para pekerja. Sebagaimana di dalam kewajiban pajak, dan lebih khusus lagi adalah pajak yang 
tersebar untuk income, capital dan warisan, itu terdapat sesuatu yang bisa menekan tingkat kesenjangan kekayaan.

Keempat, mazhab-mazhab Sosialism juga berbeda-beda dalam memandang lembaga yang akan diserahi untuk mengendalikan proyek-proyek dalam sistem Sosialis tersebut. Sebagai contoh, para penganut Sosialism Kapitalis menghendaki agar pengaturan produksi dan pendistribusiannya diserahkan kepada negara. Sementara pada saat yang sama, penganut Naqobiyah menghendaki agar pengaturan tersebut diserahkan kepada sekelompok pekerja yang terorganisir, dan di bawah komando pimpinan-pimpinan mereka.

Teori-teori Sosialis yang paling masyhur dan paling banyak pengaruhnya adalah teori Karl Marx. Dan teori-teori tersebut telah menguasai dunia Sosialis. Kemudian dengan berpijak kepada teori tersebut berdirilah partai Sosialis dan negara Uni Soviet di Rusia. Bahkan, teori-teori Karl Marx ini masih tetap memiliki pengaruh yang besar hingga saat ini.

Teori Karl Marx yang paling masyhur adalah teori tentang nilai (value), yang pada dasarnya dia mengambil dari ahli ekonomi Kapitalis kemudian dia serang mereka dengan teori tersebut. Adam Smith, yang dianggap sebagai tokoh mazhab Liberalisme di Inggris, yang juga dianggap sebagai bapak Ekonomi Politik atau bapak sistem ekonomi Kapitalis, telah mendefinisikan nilai dengan mengatakan: "Nilai barang apapun itu amat bergantung kepada usaha yang dicurahkan untuk menghasilkannya. Karena itu, nilai barang yang proses produksinya menghabiskan waktu dua jam tentu melebihi nilai barang yang proses produksinya tidak membutuhkan waktu, kecuali satu jam." Setelah Adam Smith, ada Richardo 
F. yang mencoba menjelaskan teori usaha tersebut. Dalam mendefinisikan nilai, dia mengatakan: "Yang menentukan nilai barang itu, bukan semata-mata kadar usaha yang secara langsung dikorbankan untuk menghasilkannya, melainkan harus didasarkan kepada usaha yang telah dikorbankan sebelumnya untuk menghasilkan alat-alat dan perlengkapan-perlengkapan yang dipergunakan dalam proses produksi." Dengan kata lain, Richardo menyakini bahwa nilai suatu barang sangat tergantung kepada biaya (cost) produksinya. Dimana biaya (cost) ini dapat dikembalikan kepada satu unsur, yaitu usaha.

Setelah itu, Karl Marx datang dan mengambil teori Richardo ini, yaitu teori tentang nilai menurut sistem ekonomi Kapitalis, sebagai senjata untuk menyerang kepemilikan individu (private propherty) dan menyerang sistem ekonomi Kapitalis secara umum. Dia mengatakan, bahwa sumber satu-satunya bagi nilai itu adalah usaha yang dikorbankan untuk menghasilkan suatu barang. Dimana, para pemilik modal dalam sistem Kapitalis telah membeli tenaga pekerja dengan upah yang tidak lebih dari sekedar bisa untuk mempertahankan hidupnya agar bisa bekerja. Kemudian pekerja tersebut mencurahkan tenaganya untuk menghasilkan barang-barang yang nilainya jauh melebihi upah yang diberikan kepada pekerja tersebut.

Karl Marx menyebut perbedaan antara yang dihasilkan oleh pekerja dengan upah riil yang diberikan kepada pekerja tersebut dengan sebutan nilai lebih tenaga kerja (surplus labor and value). Dia menyebut apa yang dirampas oleh para pemilik modal dan pemilik kerjaan terhadap hak-hak para pekerja itu dengan sebutan income, laba, guna modal 
(capital utility), yang sebelumnya sama sekali belum pernah dianjurkan.

Karl Marx berpendapat bahwa mazhab-mazhab Sosialism yang ada sebelumnya dalam memenangkan pikaran-pikirannya biasa bersandar kepada fitrah yang dimiliki oleh manusia, yaitu kecintaan manusia pada keadilan dan keberpihakannya kepada orang yang didzalimi. Maka, mazhab-mazhab Sosialism tersebut kemudian membuat cara-cara (baca: mekanisme) baru yang diyakininya mampu untuk diterapkan di tengah masyarakat. Dengan cara-cara semacam itulah, maka ia sampai kepada para penguasa, kaum borjuis dan kelas atas sehingga mendorong mereka untuk menerapkannya. Akan tetapi, Karl Marx tidak menjelaskan mazhabnya dengan cara semacam itu, bahkan dia tidak menempuh cara-cara yang mereka pergunakan. Karl Marx telah membangun mazhabnya dengan berpijak pada pandangan filsafat materialisme historis, atau yang disebut dengan teori Dialektika . Dia berpendapat bahwa tegaknya sistem baru dalam masyarakat itu akan bisa sempurna semata-mata karena diterapkannya undang-undang perekonomian serta sesuai dengan hukum dialektika dalam masyarakat, tanpa adanya intervensi dari pihak pembuat hukum atau pihak yang membangun.

Dan Sosialism Karl Marx ini kemudian disebut dengan sebutan Sosialism Ilmiah, untuk membedakan dengan cara-cara Sosialis sebelumnya, atau untuk membedakan dengan Sosialism yang disebut dengan Sosialism Utopia (Utopia Sisialism). Dimana pandangan (teori) Sosialism Karl Marx tersebut dapat diringkas sebagai berikut: 
Sistem masyarakat yang ada pada masa Karl Marx, sebenarnya merupakan akibat dari kondisi ekonomi, dimana perubahan-perubahan yang dialami sistem tersebut semata-mata bisa dikembalikan kepada satu sebab, yaitu perjuangan kelas (class struggle) dalam rangka memperbaiki kondisi kelas tersebut secara materi. Sejarah telah menceritakan kepada kita, bahwa perjuangan ini ketika itu selalu berakhir dengan satu bentuk, yaitu menangnya kelas yang lebih dominan jumlahnya dan lebih jelek kondisinya atas kelas orang-orang kaya dan kelas yang jumlahnya lebih sedikit. Inilah yang kemudian disebut dengan hukum Dialektika Sosial. Dimana, hukum ini masih bisa berlaku untuk masa-masa mendatang, sebagaimana hukum ini sebelumnya pernah terjadi.

Pada masa dahulu, perjuangan ini memang terjadi. Yaitu antara kelas orang-orang merdeka dengan kelas para budak, kemudian antara kelas orang-orang terpandang dengan kelas orang-orang awam. Setelah itu, antara kelas orang-orang terpandang dengan kelas para petani. Begitu pula, antara kelas para pemimpin formal dengan kelas para pemimpin non formal dalam sistem kelompok. Dimana ketika itu, perjuangan ini selalu berakhir dengan menangnya kelas orang-orang yang terdzalimi yang jumlahnya memang lebih banyak atas kelas orang-orang dzalim yang jumlahnya memang sedikit. Akan tetapi setelah kemenangan tersebut, kelas orang-orang yang terdzalimi itu kemudian menjelma menjadi kelas orang dzalim yang baru, sebagai tindakan defensif.

Maka sejak revolusi Prancis, perjuangan ini bisa menjadi perjuangan antara kelas menengah (borjuis) dengan kelas 
para pekerja (proletar). Dimana yang lebih unggul pasti akan menjadi pengendali proyek-proyek perekonomian dan menjadi pemilik modal (capitalis) sebagaimana yang terjadi pada kelas defensif. Dan dengan cara inilah, kemudian bangkitlah kelas para pekerja (proletar) tersebut. Dimana, kelas proletar tersebut tidak memiliki modal (capital) apapun, namun jumlahnya lebih dominan ketimbang kelas borjuis. Karena itu, selalu terjadi konfrontasi antara kepentingan-kepentingan yang ada pada dua kelas tersebut. Dimana sebab-sebabnya bisa dikembalikan kepada sebab-sebab ekonomi.

Hal itu terjadi karena sistem produksi saat ini tidak lagi berjalan seiring dengan sistem kepemilikan. Karena produksi tidak mungkin bisa sendirian. Artinya, seseorang tidak bisa melakukan produksi dengan seorang diri, sebagaimana yang pernah dilakukan pada zaman dahulu. Akan tetapi --kini produksi itu telah berubah-- menjadi kegiatan kolektif. Dimana dalam hal ini, masing-masing individu saling bekerja sama. Sementara itu, sistem kepemilikan tidak pernah berubah seiring dengan perubahan sistem produksi tersebut. Sehingga kepemilikan individu tetap saja ada, bahkan kepemilikan inilah yang masih menjadi asas sistem tersebut dalam masyarakat sekarang. Sebagai akibatnya, kelas pekerja (proletar) -- padahal dia ikut terlibat dalam berproduksi-tidak bisa ikut memiliki modal (capital) dan tetap saja di bawah belas-kasihnya para pemilik modal (capitalis), dimana mereka secara langsung tidak melibatkan diri dalam berproduksi. Sementara pada saat yang sama, para kapitalis itu selalu mengeksploitir para pekerja tersebut. Dimana, mereka tidak akan memberikan upah kepada para pekerja 
tersebut, kecuali sesuai dengan kadar kecukupannya. Dan seorang pekerja dipaksa untuk menerimanya, karena dia tidak berhak memiliki kecuali terhadap apa yang telah dia lakukan. Maka, perbedaan antara nilai orang yang berproduksi dengan upah pekerja --dan inilah yang disebut oleh Karl Marx dengan sebutan nilai lebih tenaga kerja (surplus labor and value)-- itu bisa melahirkan laba, yang sebenarnya dengan laba tersebut seorang kapitalis masih bisa menciptakan pengaruh, padahal yang adil seharusnya upah tersebut merupakan bagian seorang pekerja.

Maka, peperangan itu tetap akan meletus antara dua kelas ini sampai sistem kepemilikan dengan sistem produksi tersebut menjadi seimbang, artinya sampai kepemilikan tersebut menjadi kepemilikan bersama (koletif). Dan --apabila peperangan tersebut telah meletus-- peperangan ini akan berakhir dengan kemenangan di pihak kelas pekerja (proletar) karena mengikuti hukum dialektika masyarakat. Sebab kelas pekerja itulah kelas yang paling buruk kondisinya dan jumlahnya paling dominan. Sedangkan bagaimana kelas pekerja (proletar) tersebut bisa menang, termasuk apa sebab-sebab kemenangannya? Itulah yang dinyatakan oleh hukum dialektika sosial (masyarakat).

Karena itu, sistem kehidupan ekonomi yang ada, itu juga mencakup benih-benih komunitas yang akan datang. Dan sistem tersebut harus dihilangkan dengan dibuatnya undang-undang perekonomian yang yang tunduk kepadanya. Karena itu, pada suatu saat kelas menengahlah (borjuis) yang menang atas kelas orang-orang terpandang (asyraf), sehingga kelas borjuis -lah yang memainkan peranan penting dalam kehidupan perekomian. Karena kelas inilah yang menguasai 
modal (capital). Akan tetapi, kini otoritas kelas tersebut telah berakhir, dan tiba giliran kelas proletar yang pada saat itu tergusur dari tempatnya.

Itulah yang ditentukan oleh Law of Capitalist Accumulation (hukum tentang akumulasi modal) dan persaingan bebas. Dengan terjadinya hukum tersebut, maka jumlah pemilik modal menjadi berkurang dan jumlah pekerja honorer terus bertambah. Sebagaimana ketika persaingan bebas itu terjadi, maka ia juga akan menyebabkan melimpahnya produk (barang komsumtif) secara berlebihan, sehingga kuantitas produk tersebut akan melebihi apa yang mampu dibeli oleh konsumen dari kalangan pekerja, karena mereka mendapatkan honor yang tidak cukup. Dan, itulah yang akan menyebabkan krisis (resesi). Akibatnya, sebagian orang --karena asalnya kaya raya-- terpaksa melepaskan kekayaan (capital) mereka, kemudian mereka masuk dalam kelas pekerja.

Sistem ini terjadi ketika tikaman krisis tersebut semakin kuat, dan hampir mendekati saat-saat kejatuhannya, serta ketika jumlah kaum kapitalis (pemilik modal) terus berkurang melebihi jumlah pekerja. Lalu tidak lama kemudian, tibalah saat-saat terjadinya krisis yang lebih besar daripada sebelumnya, dan itulah malapetaka yang dahsyat. Karena malapetaka tersebut bisa merobohkan sendi-sendi sistem ekonomi Kapitalis, lalu di atas reruntuhan sistem ekonomi kapitalis tersebut, berdirilah sistem Sosialis.

Marx berpendapat bahwa berdirinya Sosialis itu adalah peran akhir dialektika historis . Karena ketika Sisialis ituz enghancurkan kepemilikan individu (private propherty), di sana sebenarnya tidak pernah ada seruan untuk 
menghancurkan kelas-kelas di dalam antara kelas-kelas tersebut.

Law of Capitalist Accumulation yang diajarkan oleh Karl Marx tersebut adalah berasal dari ajaran sistem ekonomi Kapitalis. Dan secara ringkas, bisa dipaparkan, bahwa di sana terjadi suatu gerakan yang mentransfer kerja dan modal dari sebagian proyek yang satu kepada sebagian proyek yang lain; yaitu ketika sebagian proyek tersebut besar, pada saat proyek yang lain masih kecil. Semuanya ini merupakan kondisi yang menjelaskan terjadinya Capitalist Accumulation (akumulasi modal) dalam berproduksi. Apabila anda membahas tentang jumlah proyek dalam satu tempat, seperti pabrik cokelat, maka anda akan menemukan bahwa jumlah proyek tersebut telah berkurang, ketika pada saat yang sama, jumlah orang borjuis yang dipergunakan dalam setiap proyek karena kuatnya produk mereka, malah bertambah. Maka, dalam hal ini bisa dibuktikan bahwa salah satu bentuk dari produk tersebut telah mengalami sentralisasi. Karena dengan mengambil produk yang besar itu biasanya bisa menggantikan posisi produk yang kecil. Kalau sebelumnya jumlah pabrik tersebut 10 , misalnya, maka pabrik tersebut bisa menjadi 4 atau 5 pabrik besar saja, sementara pabrik-pabrik yang lain bisa dimusnahkan.

Sedangkan persaingan bebas yang dikatakan Marx adalah sama dengan kaidah kekebasan berusaha. Yaitu, masing-masing orang memiliki hak untuk memproduksi apa saja yang dia inginkan sesukanya.

Sedangkan krisis-krisis ekonomi yang dikatakan Karl Marx, itu sebenarnya dimaksudkan bagi tiap gejolak yang muncul secara tiba-tiba, yang bisa mempengaruhi keseimbangan 
ekonomi (economic equilibrium). Dimana krisis tertentu bisa saja meliputi semua bentuk krisis, yang sebenarnya bisa dipecahkan dengan satu bentuk produksi tertentu, sebagai akibat dari sebab-sebab tertentu, yang terjadi karena hilangnya keseimbangan (equilibrium) antara produksi dengan konsumsi. Kejadian ini bisa saja muncul karena produksinya yang melebihi batas, atau terlampau minim, atau bisa saja muncul karena konsumsinya melampaui batas atau terlalu minim.

Sedangkan krisis umum yang terjadi secara preodik, itu sebenarnya bisa muncul dalam bentuk gejolak yang dahsyat yang bisa menggoncang sendi-sendi sistem perekonomian tersebut secara keseluruhan. Dimana krisis tersebut merupakan titik yang memisahkan antara fase kemakmuran dengan fase resesi. Fase kemakmuran tersebut rentang waktunya biasanya berkisar antara 3 sampai 5 tahun. Sedangkan fase resesi tersebut rentang waktunya juga sama.

Krisis-krisis umum yang terjadi secara preodik itu, memiliki sifat-sifat khusus yang bisa dipilah-pilah, dan yang paling penting ada tiga. Yaitu, pertama, bersifat umum. Maksudnya, krisis tersebut bisa menimpa semua aspek kegiatan perekonomian di suatu negeri, atau minimal mayoritas aspek kegiatan perekonomiannya. Krisis itu pertama kali terjadi di salah satu bagian negara, kemudian menjalar ke seluruh negara. Setelah itu, menjalar ke negara-negara lain yang sebelumnya telah mencapai tingkat kemajuan ekonomi, dimana kemajuan ekonomi tersebut sebelumnya telah mampu mengikat hubungan dengan sebagian negara yang lain secara terus-menerus. Kedua, bersifat preodik. Maksudnya, krisis tersebut bisa terjadi 
setiap saat secara preodik. Sementara fase yang memisahkan antara krisis yang satu dengan krisis yang lain, berkisar antara 7-11 tahun. Hanya saja, terjadinya tidak pada waktu-waktu yang tetap, melainkan terjadi secara preodik. Sedangkan sifat ketiga adalah melimpahnya produksi, karena para pemilik proyek menghadapi masalah besar ketika akan melakukan transaksi terhadap produk-produknya. Maka, jumlah penawaran (supplay) bertambah melebihi jumlah permintaan (demand) dalam banyak produk, sehingga, terjadilah krisis.

Karl Marx berpendapat, bahwa krisis-krisis tersebut bisa menyebabkan sebagian orang kehilangan kekayaan (capital) mereka. Sehingga jumlah pemilik modal (capitalis) akan terus menurun, sedangkan jumlah pekerja terus bertambah. Dan inilah yang menyebabkan terjadinya krisis besar dalam masyarakat, yang bisa menghancurkan sistem sebelumnya.

Inilah ringkasan tentang Sosialism, termasuk Komunisme. Dari kesimpulan ini, menjadi jelas bahwa mazhab-mazhab Sosialism, termasuk di antaranya adalah Komunism, semuanya berusaha untuk mewujudkan kesamaan (equality) secara riil di antara individu.

Adakalanya kesamaan dalam masalah jasa, atau alat-alat produksi, atau kesamaan-kesamaan secara mutlak. Masing-masing bentuk kesamaan (equality) ini jelas mustahil terjadi, karena hal itu merupakan fenomena yang halusinatif. Hal itu adalah karena kesamaan (equality), dari segi kesamaan (equality) itu sendiri sebenarnya tidak bisa terjadi secara riil, karena itu tentu kesamaan (equality) tersebut adalah sesuatu yang tidak pernah terjadi.

Adapun ketidakmungkinan terjadinya kesamaan (equality) tersebut adalah karena manusia, dengan karakter 
fitrah mereka yang menjadi dasar kelahirannya, adalah berbeda-beda tingkat kekuatan tubuh dan akalnya, termasuk berbeda-beda tingkat pemenuhan kebutuhan-kebutuhannya. Sehingga kesamaan (equality) di antara mereka, tentu tidak akan mungkin pernah terjadi. Karena kalau di antara mereka dipersamakan dalam pemerolehan barang-barang dan jasa dengan cara paksa, dengan mempergunakan hukum besi oligarki (the iron low of oligrachy), maka mereka masih tetap tidak mungkin sama dalam mempergunakan kekayaan (capital)-nya untuk berproduksi dan pemanfaatannya. Juga tidak mungkin terjadi kesamaan (equality) di antara mereka, sesuai dengan kadar yang dibutuhkan untuk memenuhi kebutuhan-kebutuhan mereka. Karena itu mempersamaratakan di antara mereka adalah pandangan yang mustahil.

Bahkan mempersamaratakan di antara manusia itu sendiri, dengan perbedaan-perbedaan kemampuannya, justru bisa dinilai jauh dari keadilan, yang konon orang-orang Sosialis terus berupaya mewujudkannya. Karena itu, perbedaan kekayaan yang dimiliki manusia, serta perbedaan-perbedaan dalam pemerolehan jasa dan alat-alat produksi adalah masalah yang pasti terjadi dan alami sifatnya. Maka, setiap upaya untuk mempersamaratakan pasti akan menemukan kegagalan, karena hal itu bertentangan dengan fitrah ketidaksamaan yang terjadi di antara manusia.

Sedangkan penghabusan kepemilikan khusus (private propherty) dengan penghapusan secara total itu adalah bertentangan dengan fitrah manusia. Karena kepemilikan atau pemerolehan itu merupakan salah satu wujud naluri mempertahankan diri (survivel instink). Dan hal itu pasti 
senantiasa ada pada manusia. Karena hal itu merupakan fitrah manusia, dimana fitrah tersebut merupakan bagian dari dirinya serta salah satu wujud potensi alamiahnya. Karena itu, tidak mungkin menghapusnya. Karena kepemilikan dan pemerolehan tersebut naluriah sifatnya. Maka, tiap masalah yang bersifat naluriah, jelas tidak mungkin dicabut dari diri manusia, selama kehidupan masih mengakar di dalam dirinya. Bahkan setiap usaha untuk menghapusnya, sebenarnya hanyalah tindakan penghancuran terhadap manusia, yang akan menyebabkan gejolak (kegoncangan). Oleh karena itu, yang semestinya dilakukan adalah bagaimana mengatur naluri tersebut, bukan menghapusnya.

Akan halnya dengan penghapusan kepemilikan secara parsial itu harus dilihat terlebih dahulu: Apabila yang dibatasi adalah kadar kepemilikan barang dengan kadar tertentu, yang tidak boleh melebihi kadar tersebut, maka tindakan semacam itu merupakan tindakan pembatasan terhadap kepemilikan dengan cara pemberangusan (perampasan). Karena tindakan semacam itu, adalah sama dengan membatasi gerak (aktivitas) manusia serta menganggap usahanya tidak pernah ada, dus menganggap rendah hasilnya. Dan, ketika manusia tidak diperbolehkan untuk memperoleh apa yang melebihi kadar yang telah ditetapkan, maka dia harus dihentikan sampai pada batas tertentu, sehingga dia diharamkan untuk melanjutkan aktivitasnya. Begitu pula dengan suatu kelompok (jama'ah), juga diharamkan untuk memanfaatkan usaha (jerih-payah) mereka.

Sedangkan membatasi kadar kepemilikan barang dan jasa dengan cara (mekanisme) tertentu, dengan tanpa melakukan pembatasan yang memakai cara pemberangusan 
(perampasan) itu tentu saja diperbolehkan. Karena hal itu berarti tidak membatasi aktivitas manusia. Hal ini dilakukan semata-mata karena untuk mengatur pemerolehan harta di antara individu, yaitu membantu mencurahkan tenaga dan menambah aktivitas.

Sedangkan bila penghapusan kepemilikan dengan penghapusan secara parsial itu melalui cara (mekanisme) pembatasan kekayaan tertentu, yang seseorang dilarang untuk memilikinya, serta mebiarkannya untuk memiliki yang lain, tanpa dibatasi dengan kadar tertentu, maka cara (mekanisme) semacam itu harus dilihat terlebih dahulu: Apabila karakter kekayaan tersebut --yang diciptakan memang sengaja untuk dimanfaatkan-- tidak bisa diperoleh oleh satu orang saja, sementara yang lain tidak, selain dengan membawa kesengsaraan sekelompok orang, karena secara pasti, tiap-tiap orang sama-sama membutuhkan jasa (manfaat)-nya, seperti jalan-jalan umum, lapangan, sungai, laut dan sejenisnya, maka larangan pemilikan atas seseorang saja adalah masalah yang wajar, yang telah ditentukan oleh karakter kekayaan (harta) tersebut. Sehingga, dalam hal semacam itu tidak ada masalah, yaitu apabila kekayaan tersebut dilarang untuk dimiliki oleh satu orang saja, sementara yang lain tidak.

Akan halnya dengan karakter kekayaan yang tidak mengharuskan semacam itu, maka harus dilihat: Apabila kekayaan tersebut disamakan dengan kekayaan yang karakternya tidak mungkin dimiliki oleh individu, kecuali mengakibatkan sekelompok orang menderita, seperti kekayaan yang asalnya memang tidak bisa dimiliki semuanya oleh seseorang, semisal air dan kandungan-kandungan bumi 
yang tidak akan pernah habis. Maka, melarang seseorang untuk memilikinya tidak ada masalah. Karena kekayaan tersebut karakternya sama dengan kekayaan yang tidak mungkin dimiliki oleh seseorang, selain dengan kesengsaraan sekelompok orang. Sementara yang menjadikannya sama seperti kekayaan tersebut adalah karena asalnya memang tidak mungkin dimiliki oleh seseorang, kecuali dengan membawa akibat kesengsaraan pada sekelompok orang. Sedangkan bila kekayaan tersebut tidak disamakan dengan bentuk kekayaan di atas, seperti kekayaan-kekayaan yang lainnya, maka tidak boleh melarang seseorang untuk memilikinya. Karena dengan begitu, berarti telah membatasi kepemilikan harta kekayaan dengan mentolelir sebagian yang lain, sedangkan yang lain tidak. Dan dalam hal ini statusnya adalah sama seperti membatasi kepemilikan harta kekayaan dengan kadar tertentu, termasuk membenarkan pembatasan kepemilikan dengan cara pemberangusan (perampasan), termasuk mengumpulkan hasil-hasilnya. Karena, tindakan semacam itu sama dengan membatasi aktivitas manusia, mengabaikan jerih payahnya, menganggap minim hasil kerjanya serta menghentikannya bekerja ketika sudah sampai pada kadar (batas) yang diberikan kepadanya, juga ketika dia dilarang untuk menambah dari kadar (yang telah ditentukan) untuk dirinya.

Cara menghapus kepemilikan dengan penghapusan secara parsial, dalam sistem Sosialism tersebut adalah dengan pembatasan yang dilakukan dengan cara pemberangusan (perampasan), bukan pembatasan dengan cara (mekanisme) tertentu. Seperti melarang memiliki sebagian harta kekayaan, yang karena karakternya dan 
karakter asalnya memang boleh diperoleh oleh individu. Karena, bisa jadi kepemilikan tersebut juga dibatasi dengan cara pemberangusan (perampasan), semisal kepemilikan atas tanah-tanah di lapangan-lapangan tertentu. Juga bisa jadi kepemilikan tersebut dibatasi dengan hanya harta-harta tertentu, yang tidak boleh dimiliki oleh individu, semisal pembatasan terhadap pemilikan atas sarana-sarana (alat-alat) produksi. Padahal harta kekayaan ini, menurut karakternya, bisa saja dimiliki secara pribadi oleh seseorang. Dimana, pembatasan kepemilikan yang dilakukan dalam Sosialism adalah pembatasan semacam ini. Yaitu mencegah kepemilikan harta kekayaan, yang menurut karakternya bisa dimiliki secara pribadi. Karena itu, larangan terhadap kepemilikan atas harta kekayaan semacam ini sama dengan membatasi aktivitas. Baik harta kekayaan ini tertentu, seperti larangan hak waris, atau larangan memiliki jalan-jalan, rel kereta api, pabrik-pabrik dan sebagainya. Atau membiarkan negara melarang apa saja yang dipandang menurut kepentingan umum harus dilarang. Maka, semuanya tadi jelas membatasi aktivitas individu, selama harta kekayaan yang dilarang tersebut, memang karakternya, bisa dimiliki secara pribadi.

Sedangkan mengatur produksi dan distribusi secara kolektif itu sebenarnya tidak bisa dengan cara menumbuhkan gejolak dan goncangan di tengah-tengah manusia, serta menumbuhkan dendam dan permusuhan di antara mereka, yaitu antara sebagian orang dengan sebagian yang lain. Karena, cara semacam itu sebenarnya merupakan cara mewujudkan gejolak (goncangan), bukan cara untuk mengatur. Yang pasti, tidak bisa membiarkan para pekerja 
(kaum proletar) tersebut dijadikan bulan-bulanan pemilik kerja. Karena bisa jadi para pemilik kerja tersebut sangat lihai untuk memenuhi kebutuhan-kebutuhan para pekerjanya --sebagaimana yang dialami oleh para pekerja pada industri-industri yang ada di Amerika Serikat-- sehingga mereka tidak pernah merasakan adanya kedzaliman yang menimpa diri mereka pada saat menguras hasil jerih payah mereka. Maka, dalam keadaan semacam itu tidak akan pernah terjadi dialektika (perubahan) yang bisa mengatur produksi dan konsumsi.

Oleh karena itu, untuk mengaturnya harus dilakukan dengan undang-undang dan pemecahan-pemecahan (solving) yang benar, yang asasnya benar, serta sesuai dengan kondisi (realitas) masalahnya. Sementara Sosialism, dalam mengatur produksi dan distribusi, ada kalanya bersandar kepada gejolak dan goncangan-goncangan yang ditumbuhkan di kalangan pekerja, dan adakalanya bersandar kepada dialektika masyarakat, dan kadang kala dengan membuat peraturan-peraturan dan undang-undang yang tidak didasari dengan pijakan yang kokoh. Karena itu, cara pengaturannya adalah salah sejak dari asasnya.

Inilah penjelasan tentang kesalahan Sosialism dari segi Sosialism itu sendiri. Sedangkan kesalahan Sosialism Karl Marx, sebagai salah satu bentuk Sisialism, adalah bisa dilihat dari tiga aspek:

Pertama, bahwa pandangan Marx tentang teori nilai itu adalah salah dan bertentangan dengan kenyataan. Bahwa sumber satu-satunya --yang menentukan-- nilai barang itu adalah usaha yang dikorbankan dalam memproduksinya adalah bertentangan dengan kenyataan. Karena usaha yang 
dikorbankan adalah salah satu sumber nilai barang, bukan satu-satunya sumber nilai. Sebab, ternyata ada hal-hal lain, di luar usaha yang juga ikut menentukan nilai barang tersebut. Karena di sana, ternyata ada materi yang dipergunakan untuk melakukan usaha, serta ada kebutuhan tertentu terhadap jasa --yang dimiliki-- barang tersebut. Karena kadang-kadang barang tersebut mengandung manfaat (jasa) yang bisa menambah kadar usaha yang dikorbankan untuk menghasilkan barang. Seperti berburu, misalnya. Dan kadang-kadang jasa barang tersebut tidak ditemukan di pasar dan ilegal, semisal minuman khamer bagi seorang muslim. Karena itu, mengklaim usaha sebagai sumber satu-satunya bagi nilai itu tentu tidak tepat, dan tidak bisa dibuktikan pada realitas barang, dari segi barang itu sendiri.

Kedua, bahwa pernyataan Marx yang menyatakan bahwa sistem sosial (kemasyarakat) yang ada pada masanya adalah sebagai akibat dari kondisi perekonomian, dimana

berbagai perubahan yang menimpa sistem tersebut semuanya bisa dikembalikan kepada satu sebab, yaitu perjuangan (pertarungan) kelas-kelas sosial dalam rangka memperbaiki kondisi materi mereka, ini adalah pernyataan yang salah dan bertentangan dengan kenyataan serta dibangun di atas sebuah hypothesa teori yang bersifat asumtif. Sedangkan bentuk kesalahan dan kontradiksinya dengan kenyataan itu nampak dari segi historis dan empirik.

Soviet, ketika berproses menjadi negara Sosialis tidak terjadi karena akibat dialektika materialisme, juga bukan karena perjuangan (pertentangan) kelas yang menyebabkan terjadinya penggantian satu sistem dengan sistem lain sama sekali. Akan tetapi, justru adanya perebutan kekuasaan oleh 
sekelompok orang dengan melalui revolusi berdarah sehingga secara de jure Soviet bisa ditundukkan, setelah itu mulailah pemikiran-pemikiran Sosialism tersebut diterapkan kepada seluruh rakyat serta merubah sistem sebelumnya. Begitu pula kondisi yang terjadi di Republik Rakyat China (RRC), serta pemberlakukan Sosialisme di Jerman Timur, dan bukan di Jerman Barat, termasuk di negara-negara Eropa timur, dan bukan di negara-negara Eropa barat. Semuanya itu tidak terjadi sebagai akibat dari perjuangan (pertentangan) antar kelas apapun. Akan tetapi, terjadi karena cengkraman negara Sosialis atas negara-negara tersebut. Sehingga sistemnya bisa diberlakukan di sana secara menyeluruh, sama seperti yang terjadi pada sistem Kapitalis, termasuk sama seperti yang terjadi pada sistem Islam, maupun sistem apapun.

Hanya saja ada negara-negara yang mengalami proses yang sama dengan hukum (dialektika) tersebut, yaitu melakukan transformasi sistemnya dengan melalui perjuangan (pertentangan) kelas, seperti Jerman, Inggris dan Amerika Serikat; atau negara-negara Kapitalis yang di sana banyak kaum kapitalis dan kaum pekerjanya. Dan tidak terjadi di Rusia dengan sistem kekaisarannya. Juga tidak terjadi di China, yang kedua-duanya lebih besar pertaniannya daripada indutrialnya, yang di dalam kedua-duanya sangat minim jumlah kelas pekerja dan kapitalis (pemilik modal)-nya, jika dibandingkan dengan negara-negara Barat. Dan meskipun ada kelas-kelas antara kelas kapitalis (pemilik modal) dengan kelas pekerja di negara-negara Eropa Barat dan Amerika, tetapi negara-negara tersebut juga tidak berubah menjadi Sosialis, bahkan semuanya tetap menerapkan sistem Kapitalis, dimana adanya kelas pekerja dan kelas kapitalis 
tersebut sama sekali tidak mempengaruhi sistem negara-negara tersebut. Ini saja sudah cukup untuk meng counter teori Karl Marx tadi dari segi asasnya.

Ketiga, adalah yang menjelaskan kesalahan teori-teori Karl Marx. Inilah yang dia sebut dengan hukum Evolusi Sosial --atau yang juga sering disebut dengan economic determinism . Bahwa sistem kehidupan ekonomi itu harus dihilangkan dengan undang-undang perekonomian yang tunduk kepadanya. Bahwa kelas borjuis -lah yang bisa menang atas kelas orang-orang terpandang, lalu kelas inilah yang menjadi pemilik kekayaan (capitalis), hingga tiba pada suatu saat yang di situ kelas tersebut meninggalkan tempatnya, lalu masuk ke kelas pekerja. Itulah yang diklaim dengan Law of Capitalist Accumulation .

Adapun kesalahan dari pernyataan ini adalah, bahwa teori Karl Marx tentang sentralisasi produksi, yang dibangun berdasarkan pertambahan jumlah pekerja dan menyusutnya jumlah pemilik modal (capitalis) itu adalah teori yang absurd - Karena di sana ada batas yang tidak bisa dilampaui oleh sentralisasi produksi sehingga sampai pada batas tertentu dan berhenti. Karena itu, perubahan (dialektika) yang digambarkan oleh Karl Marx tersebut tidak layak. Sebab telah terjadi penggabungan antara faktor-faktor produksi yang sifatnya terpisah-pisah sampai pada batas yang menjadi patokan dan batasan itu tidak mungkin dilampaui.

Disamping itu, sentralisasi produksi itu tidak pernah terjadi secara mutlak dalam bidang produksi yang paling penting sekalipun, semisal pertanian. Lalu, bagaimana hukum dialektika (perubahan) itu bisa terjadi di tengah masyarakat? Padahal, Karl Marx sendiri berasumsi, bahwa sentralisasi 
produksi itu akan diikuti sentralisasi kekayaan, yang justru akan melahirkan minimnya jumlah pemilik modal yang memonopoli kekayaan (capital) dan banyaknya jumlah pekerja yang tidak mempunyai apa-apa. Dan ini adalah salah. Sebab sentralisasi produksi itu kadang-kadang akan melahirkan banyaknya jumlah pemilik modal (capital), dan kadang-kadang malah menjadikan para pekerja menjadi pemilik modal (capitalis).

Dalam perseroan yang mempergunakan sistem saham, dimana perseroan tersebut merupakan bentuk yang umumnya dijadikan usaha besar-besaran, yang penanam sahamnya lebih banyak daripada jumlah pekerjanya. Lalu, bagaimana bisa terjadi sentralisasi produksi? Disamping itu, di pabrik-pabrik banyak terdapat pekerja yang mempunyai gaji tinggi, seperti para insinyur, ahli kimia dan para manager. Sehingga mereka mampu mengumpulkan gaji yang cukup besar dari pabrik tersebut, yang dengan kondisi semacam itu, mereka bisa menjadi konglomerat tanpa perlu membangun usaha sendiri. Sehingga dalam kondisi seperti tadi, apa yang dikatakan oleh Karl Marx tentang para pekerja yang mengalami perubahan itu tentu tidak berlaku bagi mereka.

Inilah, sekilas pandangan tentang asas-asas yang dipergunakan untuk membangun sistem ekonomi Kapitalis dan asas-asas yang dipergunakan untuk membangun sistem ekonomi Sosialis, termasuk di antaranya adalah Komunisme, serta paparan singkat tentang kebobrokan dan absurditas asas-asas tersebut. Ini dari satu aspek. Sedangkan dari aspek lain, adalah bahwa semuanya jelas bertentangan dengan metode operasional (thariqah) Islam dalam mengambil 
pemecahan-pemecahan (solusi) serta bertolak belakang dengan Islam.

Adapun dari segi kontradiksinya dengan metode operasional (thariqah) Islam dalam mengambil problem solving itu, adalah karena thariqah Islam dalam mengambil problem solving ekonomi adalah juga thariqah yang dipergunakan untuk memecahkan setiap masalah manusia. Yaitu mengkaji dan memahami realitas masalah ekonomi tersebut, lalu menggali problem solving -nya dari nash-nash syara', setelah melakukan kajian terhadap nash-nash syara' tersebut, kemudian mengukuhkan kesesuaian antara nash-nash tersebut dengan realitas-realitas masalah ekonomi tadi.

Berbeda dengan undang-undang dan pemecahan-pemecahan (solusi) ekonomi Kapitalis dan Sosialis. Karena dalam Kapitalis, pemecahan tersebut diambil dari realitas suatu masalah, setelah realitas masalahnya dikaji.

Sementara dalam sistem Sosialis, pemecahan-pemecahannya diambil dari hypothesa yang bersifat teoritis, yang diasumsikan bahwa hal-hal tadi terjadi pada masalah tersebut. Kemudian dibuatlah pemecahan (solving) yang dibangun di atas hypothesa --yang bersifat teoritis-- tersebut. Karena itu, masing-masing thariqah ini -baik Kapitalis maupun Sosialis-- adalah bertentangan dengan thariqah Islam. Sehingga orang Islam tidak boleh mengambilnya.

Sedangkan kontrasiksi sistem Kapitalis dan Sosialis termasuk Komunis dengan Islam adalah, bahwa Islam hanya mengambil hukum-hukum syara' sebagai pemecahan 
(solving)-nya, yang digali dari dalil-dalil syara'. Sedangkan pemecahan-pemecahan (solving) ekonomi Kapitalis dan Sosialis itu bukan merupakan hukum syara', melainkan sistem kufur. Menghukumi sesuatu dengan hukum-hukum tersebut adalah sama dengan menghukumi dengan selain hukum yang diturunkan oleh Allah. Maka, orang Islam tidak halal mengambilnya, dengan dalih apapun. Karena itu, mengambilnya sebagai hukumnya adalah fasik, apabila orang yang mengambil tersebut tidak meyakininya. Adapun bila dia meyakini bahwa hukum-hukum tersebut merupakan hukum-hukum yang benar, termasuk menyakini bahwa hukum-hukum Islam tidak relevan untuk era modern saat ini, dan tidak mampu menyelesaikan masalah-masalah ekonomi kontemporer, maka orang tersebut telah kafir dan kita berlindung kepada Allah --dari orang-orang tersebut. 


\section{EKONOMI}

Kata "Ekonomi" diambil dari bahasa Yunani kuno (Greek), yang maknanya adalah "mengatur urusan rumah tangga", dimana anggota keluarga yang mampu, ikut terlibat dalam menghasilkan barang-barang berharga dan membantu memberikan jasa, lalu seluruh anggota keluarga yang ada, ikut menikmati apa yang mereka peroleh. Kemudian populasinya semakin banyak dalam rumah-rumah, lalu menjadi suatu kelompok (comunity) yang diperintah oleh satu negara.

Karena itu, yang dimaksud dengan kata "Ekonomi" di sini bukanlah makna bahasa, yang berarti hemat. Juga bukan berarti kekayaan. Akan tetapi yang dimaksud di sini semata-mata adalah makna istilah untuk suatu sebutan tertentu, yaitu kegiatan mengatur urusan harta kekayaan. Baik yang menyangkut kegiatan memperbanyak jumlah kekayaan serta menjaga pengadaannya, yang kemudian dibahas dalam ilmu ekonomi, maupun yang berhubungan dengan tata cara (mekanisme) pendistribusiannya, yang kemudian dibahas dalam sistem ekonomi.

Bahwa ilmu ekonomi dan sistem ekonomi itu, meski masing-masing membahas tentang ekonomi, akan tetapi ilmu ekonomi dan sistem ekonomi adalah dua hal yang berbeda sama sekali. Dimana antara konsep yang satu dengan konsep yang lainnya tentu tidak sama. Karena sistem ekonomi itu tidak dibedakan berdasarkan banyak dan sedikitnya kekayaan, bahkan sama sekali tidak terpengaruh oleh 
kekayaan. Sebab banyak dan sedikitnya kekayaan tersebut tidak akan mempengaruhi bentuk sistem ekonomi, dari sisi manapun.

Oleh karena itu, merupakan kesalahan yang fatal, apabila menjadikan ekonomi sebagai satu pembahasan yang dianggap membahas masalah yang sama --antara ilmu dan sistem ekonomi. Karena hal semacam itu, tentu akan menyebabkan kesalahan dalam memahami masalah-masalah ekonomi yang ingin dipecahkan, bahkan akan menyebabkan buruknya pemahaman terhadap faktor-faktor produksi yang menghasilkan kekayaan, yaitu faktor-faktor produksi yang menghasilkan kekayaan dalam suatu negara. Karena mengatur urusan kelompok (comunity) dari segi pemenuhan harta kekayaan, yaitu pengadaannya, adalah satu masalah. Sedangkan mengatur urusan kelompok (community) dari segi distribusi kekayaan yang diatur, adalah masalah lain.

Maka, pembahasan tentang mengatur materi kekayaan tersebut harus dibedakan dengan pembahasan tentang mengatur pendistribusiannya. Karena pembahasan yang pertama, berkaitan dengan faktor produksi. Sedangkan pembahasan yang kedua berkaitan dengan pemikiran (konsep) tertentu. Oleh karena itu, pembahasan tentang sistem ekonomi harus dibahas sebagai sebuah pemikiran yang mempengaruhi dan terpengaruh pandangan hidup (way of life) tertentu. Lalu membahas ilmu ekonomi sebagai sebuah sains murni, yang tidak ada hubungannya dengan pandangan hidup (way of life) tertentu. Dan di antara kedua pembahasan tersebut yang paling penting adalah pembahasan tentang sistem ekonomi. Karena masalah ekonomi yang ada akan terus mengikuti 
kebutuhan-kebutuhan manusia dan alat-alat pemuas kebutuhan-kebutuhannya, termasuk pemanfaatan terhadap alat-alat pemuas kebutuhan tersebut. Sementara alat-alat pemuas tersebut terdapat pada alam. Dimana untuk menghasilkannya agar bisa memuaskan kebutuhan-kebutuhan tersebut, tidak akan sampai menimbulkan masalah utama. Hanya saja, pemenuhan kebutuhan-kebutuhan tersebut bisa mendorong manusia untuk menghasilkan alat-alat pemuas atau mengusahakannya.

Sedangkan masalah yang terjadi dalam interaksi manusia, atau dalam masyarakat, adalah muncul karena mungkin dan tidaknya manusia untuk memanfaatkan alat-alat pemuas tersebut. Artinya, masalah tersebut sebenarnya muncul karena persoalan pemerolehan manusia terhadap alat-alat pemuas tadi. Karena itulah, maka inilah yang merupakan masalah utama ekonomi, dan inilah yang seharusnya dipecahkan. Karena itu, masalah ekonomi tersebut sebenarnya muncul dari persoalan pemerolehan kegunaan (utility), bukan sebagai akibat dari masalah memproduksi alat-alat pemuas yang bisa memberikan kegunaan (utility).

\section{Asas Sistem Ekonomi}

Kegunaan (utility) adalah kemampuan suatu barang untuk memuaskan kebutuhan manusia. Maka, kegunaan (utility) tersebut terdiri dari dua hal: pertama, adalah batas kesenangan yang bisa dirasakan oleh manusia ketika 
memperoleh barang tertentu. Kedua, keistimewaan-keistimewaan yang tersimpan pada zat barang itu sendiri, termasuk kemampuannya untuk memuaskan kebutuhan manusia, dan bukan hanya kebutuhan orang tertentu saja. Kegunaan (utility) ini kadang lahir dari tenaga manusia, atau lahir dari harta kekayaan, atau dari kedua-duanya sekaligus. Sedangkan kata "tenaga manusia" itu bisa meliputi: tenaga pikiran dan tenaga fisik, yang dicurahkan (dikorbankan) untuk memperoleh suatu harta kekayaan atau manfaat suatu harta. Sementara kata "harta kekayaan" itu meliputi semua kekayaan yang bisa dimanfaatkan, untuk dijual, atau disewakan, atau ditukarkan. Kadang dengan cara mengkonsumsi zatnya --untuk dihabiskan-- seperti buah apel atau tanpa mengkonsumsi zatnya --hanya untuk diambil manfaatnya-- seperti mobil. Dan kadang dengan cara memanfaatkannya, sementara zatnya masih utuh seperti ayakan untuk disewakan, termasuk rumah kontrakan (kost) yang diperoleh oleh orang lain untuk disewa (dikontrak). Harta kekayaan juga meliputi uang, seperti emas dan perak, serta barang, seperti pakaian dan makanan, termasuk peralatan, seperti rumah tinggal dan pabrik, dan sebagainya. Karena harta kekayaan adalah sesuatu yang bisa memuaskan kebutuhan-kebutuhan manusia, sementara tenaga manusia itu tidak lain hanyalah alat untuk mendapatkan harta kekayaan tersebut, baik zat maupun kegunaan (utility)-nya, maka harta itulah yang merupakan asas bagi kegunaan (utility). Adapun tenaga manusia, hanyalah sarana yang bisa dipergunakan untuk menghasilkan harta kekayaan. Dari sinilah, maka dengan fitrahnya, manusia bisa berusaha untuk memperoleh harta kekayaan tersebut 
untuk dikumpulkan. Oleh karena itu, maka manusia dan harta kekayaan adalah sama-sama merupakan alat yang bisa dipergunakan untuk memuaskan kebutuhan-kebutuhan manusia. Dan dua-duanya merupakan kekayaan yang bisa diraih oleh manusia untuk dikumpulkan. Maka, kekayaan itu merupakan akumulasi dari harta kekayaan dengan tenaga.

Kekayaan yang diperoleh oleh seseorang, bisa jadi merupakan kekayaan yang diperoleh dari orang lain, seperti pemerolehan harta melalui hibbah (pemberian cuma-cuma). Dan bisa jadi merupakan kekayaan yang diperoleh bukan dari seseorang, seperti pemerolehan harta kekayaan alam secara langsung. Juga bisa jadi pemerolehan zat harta tersebut untuk dikonsumsi (dihabiskan zatnya) serta diambil manfaatnya, seperti pemerolehan buah apel dan rumah tinggal untuk dimiliki. Dan bisa jadi pemerolehan harta hanya untuk dimanfaatkan zatnya, seperti menyewa rumah. Juga bisa jadi pemerolehan manfaat (guna) yang lahir dari tenaga manusia, seperti konstruksi rumah dari seorang insinyur.

Pemerolehan, dengan segala kelayakannya, ini adakalanya diperoleh dengan cara membeli, mengontrak harta kekayaan dan pekerja; adakalanya dengan tanpa penukaran, seperti hibbah, waris dan pinjaman. Karena itulah, maka masalah ekonomi yang ada sebenarnya terletak pada pemerolehan kekayaan, bukan terletak pada ada dan tidaknya kekayaan tersebut. Dimana masalah tersebut berasal dari pandangan tentang pemerolehan atau kepemilikan (propherty), termasuk tentang absurditas transaksi dalam masalah kepemilikan (propherty) dan pendistribusian kekayaan di tengah-tengah manusia. Dimana masalah tersebut secara mutlak tidak lahir dari 
masalah-masalah lain. Karena itulah, maka pemecahan (solusi) dari aspek inilah yang sebenarnya merupakan asas sistem ekonomi.

Atas dasar inilah, maka asas yang dipergunakan untuk membangun sistem ekonomi tersebut berdiri di atas tiga kaidah: kepemilikan (propherty), tasharruf (baca: managemen) kepemilikan, serta distribusi kekayaan di tengah-tengah manusia.

\section{Pandangan Islam Terhadap Ekonomi}

Pandangan Islam terhadap masalah kekayaan berbeda dengan pandangan Islam terhadap masalah pemanfaatan kekayaan. Menurut Islam, sarana-sarana yang memberikan kegunaan (utility) adalah masalah tersendiri, sedangkan pemerolehan kegunaan (utility) adalah masalah lain. Karena itu, kekayaan dan tenaga manusia, dua-duanya merupakan kekayaan, sekaligus saranan yang bisa memberikan kegunaan (utility) atau manfaat. Sehingga, kedudukan kedua-duanya dalam pandangan Islam, dari segi keberadaan dan produksinya dalam kehidupan ini berbeda dengan kedudukan pemanfaatan serta tata cara pemerolehan manfaatnya. Karena itu, Islam juga ikut campur tangan dalam masalah pemanfaatan kekayaan dengan cara yang jelas. Islam, misalnya, mengharamkan pemanfaatan beberapa bentuk harta kekayaan, semisal khamer dan bangkai. Sebagaimana Islam juga mengharamkan pemanfaatan beberapa tenaga manusia, seperti dansa (tari-tarian) dan pelacuran. Islam juga mengharamkan menjual harta kekayaan yang haram untuk dimakan, serta mengharamkan menyewa tenaga untuk melakukan sesuatu yang haram dilakukan. Ini dari segi 
pemanfaatan harta kekayaan dan pemanfaatan tenaga manusia. Sedangkan dari

segi tata cara pemerolehannya, Islam telah mensyar'atkan hukum-hukum tertentu dalam rangka memperoleh kekayaan, seperti hukum-hukum berburu, menghidupkan tanah mati, hukum-hukum kontrak jasa, industri serta hukum-hukum waris, hibbah dan wasiat.

Ini berkaitan dengan pemanfaatan kekayaan dan mekanisme pemerolehannya. Sedangkan yang berkaitan dengan kekayaan itu sendiri, dari segi memprokdusinya, Islam telah mendorong dan memacu agar memproduksinya, sebagaimana ketika Islam memacu agar bekerja. Sementara itu, Islam sama sekali tidak ikut campur dalam menjelaskan tata cara meningkatkan product, termasuk kemampuan produksinya. Justru, Islam telah membiarkan manusia untuk melaksanakannya dengan sesuka hatinya.

Sedangkan dari segi keberadaannya, harta kekayaan tersebut sebenarnya terdapat dalam kehidupan ini secara alamiah, dimana Allah SWT. telah menciptakannya untuk diberikan kepada manusia. Allah SWT. berfirman:

"Dialah yang menciptakan untuk kalian semua, apa saja yang ada di bumi." (Q.S. Al Baqarah: 29)

"Allahlah yang telah menundukkan untuk kalian lautan, agar bahtera bisa berjalan di atasnya dengan kehendak-Nya, juga agar kalian bisa mengambil kebaikannya." (Q.S. Al Jatsiyat: 12 )

"Dan (Dialah) yang menundukkan untuk kalian apa yang ada di langit dan apa yang ada di bumi." (Q.S. Al Jatsiyat: 13)

"Maka, hendaknya manusia itu memperhatikan makanannya. Sesungguhnya, Kami benar-benar telah 
mencurahkan air (dari langit), kemudian Kami belah bumi dengan sebaik-baiknya, lalu Kami tumbuhkan biji-bijian di bumi itu, Anggur dan sayur-sayuran, Zaitun dan pohon Kurma, kebun-kebun yang lebat, dan buah-buahan serta rumput-rumputan, untuk kesenanganmu dan untuk binatang-binatang ternakmu." (Q.S. Abasa: 24-32)

"Dan telah Kami ajarkan kepada Daud membuat baju besi untuk kamu. guna memelihara kamu dalam peperanganmu." (Q.S. Al Anbiya': 80)

"Dan Kami ciptakan besi yang padanya terdapat kekuatan yang hebat dan berbagai manfaat bagi manusia (supaya mereka mempergunakan besi itu)." (Q.S. Al Hadid: 25)

Di dalam ayat-ayat ini serta ayat-ayat lain yang serupa, Allah telah menjelaskan, bahwa Dia-lah yang menciptakan harta kekayaan dan tenaga manusia, dan sama sekali tidak ada hubungannya dengan hal-hal lain. Semuanya ini menunjukkan, bahwa Allah SWT tidak ikut campur dalam masalah harta kekayaan, termasuk dalam masalah tenaga manusia, selain menjelaskan bahwa Dia-lah Yang telah menciptakannya agar bisa dimanfaatkan oleh manusia. Begitu pula, Allah tidak ikut campur dalam menentukan masalah bagaimana memproduksinya. Bahkan, tidak ada satu nash syara' pun yang menjelaskan bahwa Islam ikut campur dalam menentukan masalah bagaimana memproduksi kekayaan tersebut, justru sebaliknya. Kita malah menemukan banyak nash syara' menjelaskan, bahwa syara' telah menyerahkan masalah tersebut kepada manusia agar menggali harta kekayaan tersebut, juga agar memperbaharui tenaga 
manusia. Telah diriwayatkan, bahwa Nabi SAW pernah bersabda dalam masalah penyerbukan kurma:

"Kalianlah yang lebih tahu tentang (urusan) dunia kalian."

Juga terdapat riwayat hadits, bahwa Nabi SAW telah mengutus dua kaum muslimin untuk berangkat ke pandai besi Yaman, untuk mempelajari industri persenjataan. Semuanya ini menunjukkan, bahwa syara' telah menyerahkan masalah memproduksi harta kekayaan tersebut kepada manusia, agar mereka memproduksinya sesuai dengan keahlian dan pengetahuan mereka.

Oleh karena itu, amatlah jelas bahwa Islam telah memberikan pandangan tentang sistem ekonomi, sementara tentang ilmu ekonomi tidak. Dan Islam telah menjadikan pemanfaatan kekayaan serta mekanisme pemerolehan manfaat (utility) tersebut sebagai masalah yang dibahas --di dalam sistem ekonomi. Semantara, Islam tidak menyinggung masalah bagaimana cara memproduksi kekayaan dan faktor produksi yang bisa menghasilkan kekayaan, secara mutlak.

\section{Politik Ekonomi Islam}

Politik ekonomi (economic policy) adalah tujuan yang ingin dicapai oleh hukum-hukum yang dipergunakan untuk memecahkan mekanisme mengatur urusan manusia. Sedangkan politik ekonomi Islam adalah jaminan tercapainya pemenuhan semua kebutuhan primer (basic needs) tiap orang dengan pemenuhan secara menyeluruh, berikut kemungkinan tiap orang untuk memenuhi kebutuhan-kebutuhan skunder dan tersiernya sesuai dengan kadar kesanggupannya, sebagai orang yang hidup dalam 
sebuah masyarakat (society) yang memiliki life style tertentu. Islam memandang tiap orang secara pribadi, bukan secara kolektif sebagai komunitas yang hidup dalam sebuah negara. Pertama kali, Islam memandang tiap orang sebagai manusia yang harus dipenuhi semua kebutuhan primer (basic needs)-nya dengan pemenuhan secara menyeluruh. Baru, berikutnya, Islam memandangnya dengan kapasitas pribadinya untuk memenuhi kebutuhan-kebutuhan skunder dan tersiernya sesuai dengan kadar kemampuannya. Kemudian pada saat yang sama, Islam memandangnya sebagai orang yang terikat dengan sesamanya dalam interaksi tertentu, yang dilaksanakan dengan mekanisme tertentu, sesuai dengan life style tertentu pula.

Oleh karena itu, politik ekonomi Islam bukan hanya bertujuan untuk meningkatkan taraf kehidupan dalam sebuah negara semata, tanpa memperhatikan terjamin-tidaknya tiap orang untuk menikmati kehidupan tersebut. Politik ekonomi Islam juga bukan hanya bertujuan untuk mengupayakan kemakmuran manusia dengan membiarkan mereka sebebas-bebasnya untuk memperoleh kemakmuran tersebut dengan cara apapun, tanpa memperhatikan terjamin-tidaknya hak hidup tiap orang. Akan tetapi, politik ekonomi Islam adalah semata-mata merupakan pemecahan masalah utama yang dihadapi tiap orang, sebagai manusia yang hidup sesuai dengan interaksi-interaksi tertentu serta memungkinkan orang yang bersangkutan untuk meningkatkan taraf hidupnya, dan mengupayakan kemakmuran dirinya di dalam life style tertentu. Dengan demikian, politik ekonomi Islam tentu berbeda dengan politik ekonomi yang lain. 
Islam, ketika mensyari'atkan hukum-hukum ekonomi kepada manusia, Islam telah mensyari'atkan hukum-hukum tersebut kepada pribadi. Sedangkan pada saat mengupayakan terjamin-tidaknya hak hidup serta tercapai tidaknya suatu kemakmuran, Islam telah menjadikan semuanya harus direalisasikan dalam sebuah masyarakat (society) yang memiliki life style tertentu. Karena itu, Islam memperhatikan hal-hal yang menjadi tuntutan masyarakat, pada saat melihat terjamin-tidaknya kehidupan serta mungkin-tidaknya tercapainya suatu kemakmuran. Islam, bahkan, telah menjadikan pandangannya kepada apa yang dituntut oleh masyarakat (society) sebagai asas dalam memandang kehidupan dan kemakmuran.

Oleh karena itu, hukum-hukum syara' telah menjamin tercapainya pemenuhan seluruh kebutuhan primer (basic needs) tiap warga negara Islam secara menyeluruh, seperti sandang, papan dan pangan. Caranya adalah dengan mewajibkan bekerja bagi tiap laki-laki yang mampu bekerja, sehingga dia bisa memenuhi kebutuhan-kebutuhan primer (basic needs)-nya sendiri, berikut kebutuhan orang-orang yang nafkahnya menjadi tanggungannya. Kalau orang tersebut sudah tidak mampu bekerja, maka Islam mewajibkan kepada anak-anaknya serta ahli warisnya --untuk memenuhi kebutuhan-kebutuhan primernya. Atau, bila yang wajib menanggung nafkahnya tidak ada, maka baitul mal -lah yang wajib memenuhinya.

Dengan demikian, Islam telah menjamin tiap orang secara pribadi, untuk memenuhi kebutuhan-kebutuhan yang harus dipenuhi oleh manusia dalam kapasitasnya sebagai manusia, yaitu sandang, papan dan pangan. Islam juga 
mendorong orang tersebut agar bisa menikmati rizki yang halal serta mengambil hiasan hidup di dunia sesuai dengan kemampuannya. Islam juga melarang negara untuk mengambil harta orang tersebut sebagai pajak, meski hal itu merupakan kewajiban seluruh kaum muslimin, selain dari sisa pemenuhan kebutuhan-kebutuhannya, yang memang dia penuhi secara langsung dalam standar hidupnya yang wajar, meskipun hal itu merupakan kebutuhan skunder atau tersiernya.

Oleh karena itu, Islam telah menjamin terpenuhinya hak hidup tiap orang secara pribadi serta memberikan kesempatan kepada orang tersebut untuk memperoleh kemakmuran hidupnya. Sementara pada saat yang sama, Islam telah membatasi pemerolehan harta orang tersebut, yang dipergunakan untuk memenuhi kebutuhan primer (basic needs) serta kebutuhan skunder dan tersiernya dengan ketentuan yang khas, termasuk menjadikan interaksi orang tersebut sebagai interaksi yang mengikuti life style yang khas pula. Karena itu, Islam mengharamkan tiap muslim untuk memproduksi dan mengkonsumsi khamer (baca: minuman keras). Bahkan, dalam kaitannya dengan seorang muslim, Islam tidak pernah menganggap minuman keras tersebut sebagai barang ekonomi (economics good). Islam juga mengharamkan riba termasuk berhubungan dengan riba bagi siapa saja yang memiliki kewarganegaraan Islam. Bahkan, dalam hubungannya dengan mereka, Islam tidak menganggap riba tersebut sebagai barang ekonomi (economics good); baik mereka itu seorang muslim, maupun non muslim. Maka, Islam telah menjadikan hal-hal yang dituntut oleh masyarakat ketika memanfaatkan harta kekayaan tersebut, adalah 
sebagai masalah utama --yang harus diperhatikan-- ketika memanfaatkan barang-barang ekonomi (economics good) tersebut.

Dengan demikian, amatlah jelas bahwa Islam tidak memisahkan antara manusia dengan eksistensinya sebagai manusia, serta antara eksistensinya sebagai manusia dengan pribadinya. Islam juga tidak pernah memisahkan antara anggapan tentang jaminan pemenuhan kebutuhan primer (basic needs) yang dituntut oleh masyarakat dengan masalah mungkin-tidaknya terpenuhinya kebutuhan-kebutuhan skunder dan tersier mereka. Akan tetapi, Islam telah menjadikan pemenuhan kebutuhan-kebutuhan tersebut dengan apa yang dituntut oleh masyarakat sebagai dua hal yang seiring, yang tidak mungkin dipisahkan antara satu dengan yang lain. Justru Islam menjadikan apa yang dituntut oleh masyarakat tersebut sebagai asas (dasar pijakan) untuk memenuhi kebutuhan-kebutuhan yang ada.

Agar semua kebutuhan primer (basic needs) tersebut bisa terpenuhi dengan cara menyeluruh serta dimungkinkan terpenuhinya kebutuhan-kebutuhan skunder dan tersier tersebut, maka barang-barang ekonomi (economics good) yang ada harus bisa diperoleh oleh manusia sehingga mereka bisa memenuhi kebutuhan-kebutuhan tersebut. Sementara barang ekonomi (economics good) tersebut tidak mungkin diperoleh, kecuali apabila mereka berusaha mencarinya. Karena itu, Islam mendorong manusia agar bekerja, mencari rizki dan berusaha. Bahkan Islam telah menjadikan hukum mencari rizki tersebut adalah fardlu. Allah SWT berfirman:

"Maka, berjalanlah di segala penjurunya, serta makanlah sebagian dari rizki-Nya." (Q.S. Al Mulk: 15) 
Hanya saja, tidak berarti bahwa Islam ikut campur dalam memproduksi kekayaan atau menjelaskan bagaimana cara meningkatkan jumlah produksinya, atau berapa kadar yang diproduksinya. Karena hal itu tidak ada sangkut pautnya dengan masalah --sistem ekonomi-- tersebut. Akan tetapi Islam hanya mendorong untuk bekerja dan mencari harta.

Banyak hadits yang mendorong agar mencari harta. Dalam sebuah hadits: Bahwa Rasulullah SAW telah menyalami tangan Sa'ad Bin Mu'adz ra., dan ketika itu kedua tangan Sa'ad ngapal (bekas-bekas karena dipergunakan bekerja). Kemudian hal itu ditanyakan oleh Nabi SAW, lalu Sa'ad menjawab: "Saya selalu mengayunkan skrop dan kapak untuk mencarikan nafkah keluargaku." Kemudian Rasulullah SAW menciumi tangan Sa'ad dengan bersabda: "(Inilah) dua telapak tangan yang disukai oleh Allah SWT." Rasulullah SAW juga bersabda:

"Tidaklah seseorang makan sesuap saja yang lebih baik, selain ia makan dari hasil kerja tangannya sendiri."

Ada riwayat, bahwa Umar Bin Khattab pernah berjalan melintasi suatu kaum di Qurra', lalu beliau melihat mereka duduk dengan menundukkan kepala mereka. Kemudian beliau bertanya: "Siapakah mereka itu?" Kemudian ada yang menjawab: "Mereka adalah orang-orang yang bertawakkal." Lalu beliau berkata: "Tidak, sama sekali tidak. Justru mereka yang --dikatakan-- bertawakkal itu adalah orang-orang yang memakan harta kekayaan orang. Apakah kalian ingin aku tunjukkan siapakah orang-orang yang bertawakkal itu?" Maka, ada yang menjawab: "Tentu." Lalu beliau berkata: "Dialah orang yang menanam benih di dalam tanah, kemudian bertawakkal kepada Tuhannya." 
Demikianlah, kita banyak menemukan ayat-ayat dan hadits-hadits yang semuanya mendorong agar bekerja dan mencari rizki serta bekerja untuk memperoleh harta, sebagaimana ayat-ayat dan hadits-hadits tersebut juga mendorong agar menikmati harta serta makan makanan yang halal. Allah SWT berfirman:

"Katakanlah: 'Siapakah yang mengharamkan perhiasan dari Allah yang telah dikeluarkan-Nya untuk

hamba-hamba-Nya dan (siapa pulakah yang mengharamkan) rizki yang baik." (Q.S. Al A'raf: 32)

"Sekali-kali janganlah orang-orang yang bakhil dengan harta yang Allah berikan kepada mereka dari karunia-Nya menyangka, bahwa kebakhilan itu baik bagi mereka. Sebenarnya kebakhilan itu adalah buruk bagi mereka. Harta yang mereka bakhilkan itu akan dikalungkan kelak di lehernya di hari kiamat." (Q.S. Ali Imran: 180)

"Makanlah di antara rizki yang baik yang telah Kami berikan kepadamu." (Q.S. Thaha: 81)

"Hai orang-orang yang beriman, nafkahkanlah (di jalan Allah) sebagian dari hasil usahamu yang baik-baik dan sebagian dari apa yang Kami keluarkan dari bumi untuk kamu." (Q.S. Al Baqarah: 267)

"Hai orang-orang yang beriman, janganlah kamu haramkan apa-apa yang baik yang telah Allah halalkan bagi kamu." (Q.S. Al Maidah: 87)

"Dan makanlah makanan yang halal lagi baik yang telah Allah berikan kepadamu." (Q.S. Al Maidah: 88)

Ayat-ayat ini serta ayat-ayat sejenis lainnya telah menjelaskan dengan tegas, bahwa hukum-hukum syara' yang berkaitan dengan ekonomi diarahkan untuk mendapatkan 
harta kekayaan serta menikmati rizki yang halal. Islam telah mewajibkan bekerja kepada tiap orang serta memerintahkan mereka agar memanfaatkan kekayaan yang mereka peroleh. Semuanya itu dalam rangka mewujudkan kemajuan taraf perekonomian dalam suatu negara, dus memuaskan kebutuhan-kebutuhan primer (basic needs) tiap orang, serta memberikan kesempatan kepada orang tersebut agar bisa memenuhi kebutuhan-kebutuhan skunder atau tersiernya.

Sementara untuk mengurusi pemerolehan harta kekayaan seorang muslim, Islam --ketika mensyari'atkan hukum-hukum yang menyangkut tata cara yang dipergunakan manusia untuk mengumpulkan kekayaan-- telah membuat tata cara (mekanisme) tersebut dalam bentuk yang sangat mudah (tidak mempersulit). Sebab, Islam telah menentukan sebab-sebab kepemilikan serta akad (transaksi) yang dipergunakan untuk melangsungkan pertukaran hak milik (propherty), sementara --di sisi lain, yaitu ketika Islam tidak ikut campur dalam menentukan bagaimana cara memproduksi kekayaan-- Islam telah membiarkan manusia bebas membuat uslub (baca: cara yang bersifat teknis) dan sarana-sarana yang dipergunakan.

Islam telah menjadikan sebab-sebab kepemilikan dan transaksi-transaksi tersebut dalam bentuk garis-garis besar, yang memuat kaidah-kaidah dan hukum-hukum syara', dimana berbagai persoalan kemudian bisa dimasukan ke dalam kaidah dan hukum tersebut, sehingga berbagai hukum yang baru bisa dianalogkan kepada kaidah dan hukum tersebut. Islam telah mensyari'atkan bekerja sekaligus menjelaskan hukum-hukumnya. Bahkan Islam telah membiarkan manusia bekerja --asalkan halal-- baik sebagai 
tukang kayu, tukang sepatu, pekerja (buruh), petani maupun yang lain. Islam juga telah menjadikan hadiah, di satu sisi dianalogkan kepada --misalnya-- pemberian, dengan menjadikannya sebagai salah satu sebab kepemilikan. Islam juga telah menjadikan ijarah (baca: akad kontrak jasa), dalam satu kondisi dianalogkan dengan --misalnya-- wakalah (akad perwakilan), yaitu hak seorang wakil untuk memperoleh upah.

Dengan demikian, kita bisa menemukan sebab-sebab kepemilikan dan transaksi tersebut sama-sama telah dijelaskan oleh As Syari' (baca: Allah). Dimana, As Syari' telah menentukannya secara umum, sehingga hal-hal tersebut bisa berlaku dalam setiap kasus yang terus berkembang. Akan tetapi, kasus-kasus tersebut tidak akan berkembang dengan mengikuti perkembangan mu'amalah. Sebab, manusia wajib terikat dengan mu'amalah-mu'amalah yang telah dinyatakan oleh syara'. Hanya bedanya, mu'amalah-mu'amalah tersebut bisa diberlakukan untuk tiap kasus yang terus berkembang, sampai seberapa pun perkembangan dan keberagamannya. Oleh karena itu dalam mencari harta kekayaan, seorang muslim semestinya gesit tanpa harus berhenti --meski di jalan yang dilaluinya ada rintangan-rintangan yang menghalangi dirinya untuk berusaha-- dengan disertai "kehausan" agar usahanya benar-benar bersih dan halal.

Dengan cara semacam itulah, maka tiap orang akan mampu memenuhi kebutuhan-kebutuhannya yang senantiasa menuntut untuk dipenuhi. Maka, Islam tidak cukup hanya dengan mendorong seseorang, termasuk menjadikan pemenuhan tersebut, hanya dengan kerja 
seseorang. Akan tetapi, Islam juga telah menjadikan baitul mal sebagai supplayer seluruh rakyat. Begitu pula pemeliharaan terhadap orang lemah telah dijadikan oleh Islam sebagai kewajiban negara, termasuk memenuhi kebutuhan-kebutuhan umat sebagai salah satu kewajibannya. Sebab, negara mempunyai kewajiban untuk melayani kepentingan umat. Imam Bukhari meriwayatkan dari Ibnu Umar yang mengatakan: Nabi SAW bersabda:

"Imam yang menjadi pemimpin manusia, adalah (laksana) pengembala. Dan hanya dialah yang bertanggungjawab terhadap (urusan) rakyatnya."

Agar negara bisa melaksanakan hal-hal yang diwajibkan oleh syara', maka syara' telah memberikan kekuasaan kepada negara untuk memungut harta kekayaan tertentu sebagai pungutan tetap, semisal jizyah dan kharaj. Syara' juga telah menjadikan harta zakat sebagai bagian harta baitul mal . Syara' juga telah memberikan wewenang kepada negara untuk memungut harta yang telah diwajibkan kepada seluruh kaum muslimin, semisal untuk perbaikan jalan, pembangunan rumah sakit, memberi makan orang-orang yang kelaparan dan lain-lain.

Begitu pula syara' telah menjadikan kepemilikan umum (colective propherty) sebagai otoritas negara yang harus dimanage oleh negara, dan tak seorangpun yang diberi izin untuk memanagenya, atau memilikinya, ataupun diberi otoritas untuk memanagenya. Sebab, kekuasaan secara umum itu adalah hak pejabat pemerintahan, dimana tidak seorang rakyat pun boleh melaksanakannya, kecuali dengan adanya mandat kekuasaan. Kepemilikan umum (colective propherty), semisal minyak, tambang besi, tembaga dan 
sebagainya, adalah kekayaan yang harus dieksplorasi dan dikembangkan dalam rangka mewujudkan kemajuan taraf perekonomian umat. Sebab, kekayaan tersebut adalah milik umat, sementara negara hanya memanagenya untuk mengembangkan dan mengelolanya. Oleh karena itu, apabila suatu negara telah mengupayakan pemenuhan kekayaan tersebut serta berusaha untuk memikul tugas melayani umat, lalu masing-masing individunya bekerja dan berupaya mencari rizki, maka kekayaan yang dipergunakan untuk memenuhi seluruh kebutuhan primer (basic needs) dengan cara menyeluruh, serta untuk memenuhi kebutuhan-kebutuhan skunder atau tersier tersebut niscaya benar-benar akan terpenuhi. Hanya saja, memajukan taraf perekonomian dengan cara mendorong tiap orang agar bekerja mencari kekayaan, dan dengan menjadikan kekayaan-kekayaan tertentu sebagai milik negara, serta mengembangkan kepemilikan umum itu sebenarnya semata-mata hanya untuk memanfaatkan kekayaan tersebut sebagai alat pemuas kebutuhan, bukan untuk kekayaan itu sendiri, bukan pula untuk suatu kebanggaan, ataupun untuk disalurkan pada kemaksiatan, penyalahgunaan kekayaan, dan kejelekan. Oleh karena itu, Rasulullah SAW bersabda:

"Siapa saja yang mencari dunia dengan cara halal, semata-mata dengan tetap menjaga dari kehinaan, maka dia akan menemui Allah SWT --sedangkan-- wajahnya bagai bulan pada malam bulan purnama. Dan siapa saja yang mencari dunia sebagai suatu kebanggaan dan perlombaan, maka dia akan menemui Allah --sementara-- dia dalam keadaan marah."

Rasulullah SAW juga bersabda: 
"Wahai anak Adam (manusia), apakah ada kepemilikan yang kau miliki kecuali apa yang engkau makan kemudian engkau habiskan, atau apa yang engkau pakai kemudian engkau lusuhkan, atau apa yang engkau sedekahkan kemudian engkau kekalkan."

Allah SWT berfirman:

"Dan janganlah kalian berbuat israf (menafkahkan harta di jalan kemaksiatan). Karena Dia tidak menyukai orang-orang yang berbuat israf." (Q.S. Al An'am: 141)

Tujuan mencari kekayaan yang diperintahkan oleh Islam itu bukan semata-mata untuk menjadi alat pemuas kebutuhan, serta untuk suatu kebanggaan, melainkan untuk menjalankan roda perekonomian secara menyeluruh sesuai dengan perintah dan larangan Allah. Islam juga telah memerintahkan kepada tiap muslim agar mencari kehidupan akhirat dengan tidak melupakan kehidupan dunia. Allah SWT berfirman:

"Dan carilah apa yang telah diberikan Allah kepadamu dari kehidupan akhirat, dan janganlah engkau melupakan bagian kehidupanmu di dunia. Dan berbuat baiklah engkau sebagaimana Allah telah berbuat baik kepadamu. Dan janganlah engkau mencari kerusakan di muka bumi ini." (Q.S. Al Qashash: 77)

Karena itu, Islam telah menjadikan falsafah ekonominya berpijak pada upaya untuk menjalankan aktivitas perekonomian dengan berpegang kepada perintah dan larangan Allah yang didasarkan pada kesadaran adanya hubungan manusia dengan Allah SWT. Dengan kata lain, Islam telah menjadikan ide yang dipergunakan untuk membangun "pengaturan urusan kaum muslimin" dalam suatu 
masyarakat, dalam kehidupan ini adalah menjadikan aktivitas perekonomian tersebut sesuai dengan apa yang diperintahkan oleh hukum-hukum syara', sebagai suatu aturan agama. Islam juga telah menjadikan "pengaturan urusan rakyat" atau mereka yang memiliki kewarganegaraan, atau menjadikan aktivitas perekonomian tersebut, terikat dengan hukum-hukum syara' sebagai suatu perundang-undangan. Sehingga mereka diberi kebolehan sesuai dengan apa yang telah diperbolehkan oleh Islam kepadanya. Dimana, mereka juga terikat dengan ketentuan (aturan) yang mengikat mereka. Allah SWT berfirman:

"Dan apa saja yang dibawa untuk kalian oleh Rasul, maka ambillah. Dan apa saja yang dilarang untuk kalian, maka tinggalkanlah." (Q.S. Al Hasyr: 7)

"Wahai para manusia, telah datang kepada kalian suatu peringatan dari tuhan kalian, serta obat bagi apa yang ada di dalam dada." (Q.S. Yunus: 57)

"Maka, hendaklah berhati-hati orang-orang yang menyimpang dari jalan-Nya, terhadap fitnah yang akan ditimpakan kepada mereka atau mereka akan ditimpakan azab yang pedih." (Q.S. An Nur: 63)

"Dan hendaknya engkau hukumi di antara mereka dengan apa yang Allah turunkan." (Q.S. Al Maidah: 48)

Keterikatan kaum muslimin dan semua orang kepada hukum-hukum ini bisa dijamin dengan adanya pembinaan, sehinga seorang muslim bisa melaksanakan pilitik ekonomi tersebut kerena terdorong oleh ketakwaan kepada Allah serta pengundang-undangan hukum syara' yang diterapkan oleh negara kepada seluruh manusia. Allah SWT berfirman: 
"Wahai orang-orang yang beriman, takutlah kalian kepada Allah. Dan tinggalkanlah semua jenis riba, bila kalian termasuk orang-orang yang beriman." (Q.S. Al Baqarah: 278)

"Wahai orang-orang yang beriman, apabila kalian berhutang dengan tempo tertentu, maka catatlah hutang tersebut." (Q.S. Al Baqarah: 282)

hingga firman-Nya:

"Kecuali jika mu'amalah itu merupakan perdagangan tunai yang kamu jalankan di antara kamu, maka tidak ada dosa bagimu (jika) kamu tidak menulisnya." (Q.S. Al Baqarah: 282)

Oleh karena itu, syara' telah menjelaskan mekanisme yang dipergunakan untuk menerapkan hukum-hukum ini, sekaligus menjelaskan tentang mekanisme yang bisa menjamin keterikatan mereka kepada hukum-hukum tersebut.

Dengan demikian nampaklah, bahwa politik ekonomi Islam tersebut telah dibangun dengan berpijak kepada asas terpenuhinya kebutuhan tiap orang sebagai individu yang hidup dalam suatu masyarakat (society) tertentu, serta asas bekerja untuk mendapatkan kekayaan dalam rangka memenuhi apa saja yang bisa memuaskan kebutuhan.

Maka, politik ekonomi Islam tersebut sebenarnya berdiri di atas satu konsep, yaitu menjalankan tindakan ekonomi berdasarkan hukum syara' yang diterapkan oleh tiap orang dengan dorongan ketakwaan kepada Allah serta dilaksanakan oleh negara, dengan melalui pembinaan dan pengundang-undangan hukum syara'. 


\section{Kaidah Umum Perekonomian}

Dengan membaca hukum-hukum syara' yang menyangkut masalah ekonomi tersebut, nampaklah bahwa Islam telah memecahkan masalah bagaimana agar manusia bisa memanfaatkan kekayaan yang ada. Dan inilah yang sesunggunya, menurut pandangan Islam, dianggap sebagai masalah ekonomi bagi suatu masayarakat (society). Sehingga ketika membahas ekonomi, Islam hanya membahas masalah bagaimana cara memperoleh kekayaan, masalah memanage kekayaan yang dilakukan oleh manusia, serta cara mendistribusikan kekayaan tersebut di tengah-tengah mereka. Atas dasar inilah, maka hukum-hukum yang menyangkut masalah ekonomi tersebut dibangun di atas tiga kaidah, yaitu kepemilikan (propherty), menagemen kepemilikan, dan distribusi kekayaan di tengah-tengah manusia.

Kepemilikan (propherty), dari segi kepemilikan itu sendiri, sebenarnya merupakan milik Allah, dimana Allah SWT adalah Pemilik kepemilikan tersebut, di satu sisi. Serta Allah sebagai Dzat Yang telah dinyatakan sebagai Pemilik kekayaan, di sisi lain. Dalam hal ini, Allah SWT berfirman:

"Dan berikanlah kepada mereka, harta dari Allah yang telah Dia berikan kepada kalian." (Q.S. An Nur: 33)

Oleh karena itu, kekayaan adalah milik Allah semata. Hanya masalahnya, Allah SWT telah menyerahkan kekayaan tersebut kepada manusia agar diatur dan dibagikan kepada mereka. Karena itu sebenarnya mereka telah diberi hak untuk memiliki harta tersebut. Sebagaimana firman Allah SWT:

"Dan nafkahkanlah apa saja yang kalian telah dijadikan (oleh Allah) berkuasa terhadapnya." (Q.S. Al Hadid: 7) 
"Dan (Allah) membanyakkan harta dan anak-anakmu." (Q.S. Nuh: 12)

Dari sinilah kita temukan, bahwa ketika Allah SWT menjelaskan tentang status asal kepemilikan kekayaan tersebut, Allah SWT menyandarkan kepada diri-Nya, dimana Allah menyatakan: "Maalillah." (harta kekayaan Allah). Sementara ketika Allah SWT menjelaskan tentang perubahan kepemilikan kepada manusia, maka Allah menyandarkan kepemilikan tersebut kepada mereka. Dimana, Allah SWT menyatakan:

"Maka, berikanlah kepada mereka harta-hartanya." (Q.S. An Nisa': 6)

"Ambillah, dari harta-harta mereka." (Q.S. At Taubah: 103)

"Maka, bagi kalian pokok harta kalian." (Q.S. Al Baqarah: 279)

"Dan harta-harta yang kalian usahakan." (Q.S. At Taubah: 24)

"Dan hartanya tidak bermanfaat baginya, bila ia telah binasa." (Q.S. Al Lail: 11)

Hanya saja, bahwa hak milik yang telah diserahkan kepada manusia (istikhlaf) tersebut bersifat umum bagi setiap manusia, secara menyeluruh. Sehingga mereka memiliki hak milik tersebut, bukan sebagai kepemilikan yang bersifat fi'liyah (riil). Sebab, esensinya mereka hanya diberi istikhlafh (wewenang untuk menguasai) hak milik tersebut. Sementara kalau ada kepemilikan orang tertentu yang bersifat fi'liyah (riil), maka Islam telah memberikan syarat, yaitu harus ada izin dari Allah SWT kepada orang tersebut untuk memilikinya. Oleh karena itu, harta kekayaan tersebut hanya bisa dimiliki 
oleh seseorang, apabila orang yang bersangkutan mendapatkan izin dari Allah SWT untuk memilikinya. Sehingga izin tersebut bermakna khusus, yaitu bahwa orang yang bersangkutan telah memiliki kepemilikan atas harta tersebut. Sedangkan wewenang setiap orang untuk menguasai kepemilikan tersebut adalah bersifat umum, dimana adanya hak milik serta wewenang orang tertentu untuk menguasai kepemilikan yang bersifat riil tersebut telah dinyatakan dengan adanya izin khusus, yang berasal dari Allah SWT, sehingga orang tersebut bisa memilikinya.

Maka syara' menjelaskan, bahwa di sana terdapat kepemilikan individu (private propherty). Sehingga tiap orang bisa memiliki kekayaan dengan sebab-sebab (cara-cara) kepemilikan tertentu. Imam Abu Dawud dari Samurah dari Nabi SAW bersabda:

"Dan siapa saja yang memagari sebidang tanah, maka tanah tersebut adalah menjadi haknya."

Disamping itu, di sana juga terdapat kepemilikan umum (colective propherty) untuk seluruh umat. Imam Ahmad Bin Hanbal meriwayatkan dari salah seorang Muhajirin yang mengatakan: Nabi SAW bersabda:

"Manusia sama-sama membutuhkan dalam tiga hal:

air, padang gembalaan dan api."

Di sana juga terdapat kepemilikan negara (state propherty). Apabila ada orang Islam meninggal dunia, sementara orang yang bersangkutan tidak mempunyai ahli waris, maka harta kekayaannya adalah hak milik baitul mal (kas negara), sebagaimana kharaj, jizyah dan harta-harta lain yang diperoleh --dengan cara yang haq-- lainnya adalah milik baitul mal. 
Apa yang menjadi hak milik baitul mal, adalah milik negara, kecuali zakat. Sehingga negara berhak mendistribusikan harta yang dimilikinya, sesuai dengan kehendaknya, dengan tetap berpijak kepada hukum-hukum syara'. Syara' juga telah menjelaskan sebab-sebab kepemilikan yang bisa dimiliki oleh seseorang, serta kondisi-kondisi tertentu yang menentukan kepemilikan umat, termasuk sebab-sebab yang dimiliki oleh negara. Syara' juga melarangan mengikuti selain ketentuan-ketentuan tersebut.

Sedangkan tentang managemen kepemilikan yang berhubungan dengan kepemilikan umum (colective propherty) itu adalah hak negara, karena negara adalah wakil umat. Hanya masalahnya, As Syari' telah melarang negara untuk memanage kepemilikan umum (colective propherty) tersebut dengan cara barter (mubadalah) atau dikapling untuk orang tertentu. Sementara memanage dengan selain kedua cara tersebut, asal tetap berpijak kepada hukum-hukum, yang telah dijelaskan oleh syara' adalah tetap diperbolehkan. Adapun memanage kepemilikan yang berhubungan dengan kepemilikan negara (state prpherty) dan kepemilikan individu (private propherty) nampak jelas dalam hukum-hukum baitul mal serta hukum-hukum mu'amalah, seperti jual-beli, penggadaian dan sebagainya.

As Syari' juga telah memperbolehkan negara dan individu untuk memanage masing-masing kepemilikannya, dengan cara barter (mubadalah) atau dikapling untuk orang tertentu (sallah) ataupun dengan cara lain, asal tetap berpijak kepada hukum-hukum yang telah dijelaskan oleh syara'.

Adapun tentang cara mendistribusikan kekayaan tersebut kepada manusia, maka hal itu dilakukan dengan mengikuti 
ketentuan sebab-sebab kepemilikan serta transaksi-transaksi yang wajar. Hanya saja, perbedaan manusia dalam masalah kemampuan dan kebutuhan akan suatu pemenuhan itu bisa menyebabkan perbedaan pendistribusian kekayaan tersebut di antara mereka. Sehingga kesalahan yang terjadi dalam pendistribusian tersebut benar-benar ada. Kemudian kesalahan tersebut akan membawa konsekuensi terdistribukannya kekayaan kepada segelintir orang saja, sementara yang lain kekurangan, sebagaimana yang terjadi akibat penimbunan alat tukar yang fixed, yaitu emas dan perak. Oleh karena itu, syara' melarang perputaran kekayaan hanya di antara orang-orang kaya semata. Kemudian, syara' mewajibkan perputaran tersebut terjadi di antara semua orang. Disamping syara' juga telah mengharamkan penimbunan emas dan perak, meskipun zakatnya tetap dikeluarkan. 


\section{JENIS-JENIS KEPEMILIKAN: KEPEMILIKAN INDIVIDU (PRIVATE PROPHERTY)}

Adalah fitrah manusia, jika dia terdorong untuk memenuhi kebutuhan-kebutuhannya. Oleh karena itu juga merupakan fitrah, jika manusia berusaha memperoleh kekayaan untuk memenuhi kebutuhan-kebutuhan tersebut, serta berusaha untuk bekerja agar bisa memperoleh kekayaan tadi. Sebab, keharusan manusia untuk memenuhi kebutuhan-kebutuhannya adalah suatu kemestian, yang tidak mungkin dipisahkan dari dirinya.

Dari sinilah, maka usaha manusia untuk memperoleh kekayaan, disamping merupakan masalah yang fitri, hal itu juga merupakan suatu keharusan. Oleh karena itu setiap usaha yang melarang manusia untuk memperoleh kekayaan tersebut, tentu bertentangan dengan fitrah. Begitu pula, setiap usaha yang membatasi manusia untuk memperoleh kekayaan dengan takaran tertentu juga merupakan sesuatu yang bertentangan dengan fitrah. Maka wajar, bila kemudian manusia tidak dihalang-halangi untukmengumpulkan kekayaan, serta tidak dihalang-halangi untuk mengusahakan pemerolehan kekayaan tersebut.

Hanya masalahnya, dalam pemerolehan kekayaan tersebut tidak boleh diserahkan begitu saja kepada manusia, agar dia memperolehnya dengan cara sesukannya, serta berusaha untuk mendapatkannya dengan semaunya, dan memanfaatkannya dengan sekehendak hatinya. Sebab, cara-cara semacam itu bisa menyebabkan gejolak dan kekacauan, serta menyebabkan keburukan dan kerusakan. 
Karena manusia memang berbeda tingkat kemampuan dan kebutuhannya akan pemuasan tersebut. Apabila mereka dibiarkan begitu saja, tentu kekayaan tersebut akan dimonopoli oleh orang-orang kuat, sementara yang lemah haram mendapatkannya, maka tentu orang-orang yang sakit dan orang-orang yang memiliki kelemahan akan binasa, sementara orang-orang yang membiarkan kemauannya tanpa terkendali akan menelan sebanyak-banyaknya. Dengan begitu masalahnya adalah, bagaimana agar manusia bisa mengumpulkan kekayaan serta berusaha untuk mendapatkannya dengan cara yang bisa menjamin terpenuhinya kebutuhan-kebutuhan primer (basic needs) semua orang, serta bisa menjamin mereka sehingga memungkinkan untuk memenuhi kebutuhan-kebutuhan skunder ataupun tersiernya, adalah suatu keharusan.

Oleh karena itulah, maka cara pemerolehan kekayaan tersebut harus dibatasi dengan mekanisme tertentu, yang mencerminkan kesederhanaan, yang bisa dijangkau semua orang dengan perbedaan tingkat kemampuan dan kebutuhan mereka, serta sesuai dengan fitrah, dimana kebutuhan-kebutuhan primer (basic needs) mereka bisa terpenuhi, berikut kemungkinan mereka untuk memenuhi kebutuhan-kebutuhan skunder ataupun tersiernya. Dari sinilah, maka kepemilikan (propherty) tersebut harus ditentukan dengan suatu mekanisme tertentu. Disamping itu, melarang suatu kepemilikan tersebut harus diberantas, karena cara semacam itu bertentangan dengan fitrah. Juga karena cara memberantas kepemilikan dengan cara perampasan tersebut akan membatasi usaha manusia untuk memperoleh kekayaan. Sebab, larangan tersebut jelas 
bertentangan dengan fitrah manusia serta akan memerangi kebebasan kepemilikan. Disamping karena cara-cara tersebut menyebabkan absurditas hubungan antar personal, serta menyebabkan keburukan dan kerusakan.

Maka, Islam hadir dengan membolehkan kepemilikan individu (private propherty) serta membatasikepemilikan tersebut dengan mekanisme tertentu, bukan dengan cara pemberangusan (perampasan). Sehingga dengan begitu, cara tersebut sesuai dengan fitrah manusia serta mampu mengatur hubungan-hubungan antar personal di antara mereka. Islam juga telah menjamin manusia agar bisa memenuhi kebutuhan-kebutuhannya secara menyeluruh.

\section{Batasan Kepemilikan Individu}

Kepemilikan individu (private propherty) adalah hukum syara' yang ditentukan pada zat ataupun kegunaan (utility) tertentu, yang memungkinkan siapa saja yang mendapatkannya untuk memanfaatkan barang tersebut, serta memperoleh kompensasi --baik karena barangnya diambil kegunaan (utility)-nya oleh orang lain seperti disewa, ataupun karena dikonsumsi untuk dihabiskan zatnya seperti dibeli-- dari barang tersebut. Kepemilikan individu (private propherty) tersebut adalah semisal hak milik seseorang atas roti dan rumah. Maka, orang tersebut bisa saja memiliki roti untuk dimakan, dijual serta diambil keuntungan dari harganya. Orang tersebut juga boleh memiliki rumah untuk 
dihuni, dijual serta diambil keuntungan dari harganya. Dimana, masing-masing roti dan rumah tersebut adalah zat. Sementara hukum syara' yang ditentukan untuk keduanya adalah izin As Syari' kepada manusia untuk memanfaatkannya dengan cara dipakai langsung habis, dimanfaatkan ataupun ditukar. Izin untuk memanfaatkan ini telah menjadikan pemilik barang -- dimana dia merupakan orang yang mendapatkan izin-- bisa memakan roti dan menempati rumah tersebut, sebagaimana dia diperbolehkan juga untuk menjualnya. Hukum syara' yang berhubungan dengan roti tersebut, adalah hukum syara' yang ditentukan pada zatnya, yaitu izin untuk menghabiskannya. Sedangkan hukum syara' yang berhubungan dengan rumah, adalah hukum syara' yang ditentukan pada kegunaan (utility)-nya, yaitu izin menempatinya.

Atas dasar inilah, maka kepemilikan itu merupakan izin As Syari' untuk memanfaatkan zat tertentu. Oleh karena itu, kepemilikan tersebut tidak akan ditetapkan selain dengan ketetapan dari As Syari' terhadap zat tersebut, serta sebab-sebab kepemilikannya. Jika demikian, maka kepemilikan atas suatu zat tertentu itu tentu bukan semata-mata berasal dari zat itu sendiri, ataupun dari karakter dasarnya, semisal karena bermanfaat (satisfaction) ataupun tidak (disatisfaction). Akan tetapi, ia berasal dari adanya izin yang diberikan oleh As Syari', serta berasal dari sebab yang diperbolehkan oleh As Syari' untuk memiliki zat tersebut, sehingga melahirkan akibatnya, yaitu adanya kepemilikan atas zat tersebut sah secara syar'i.

Oleh karena itu, Allah memberikan izin untuk memiliki beberapa zat dan melarang memiliki zat-zat yang lain. Allah 
juga telah memberikan izin terhadap beberapa transaksi serta melarang bentuk-bentuk transaksi yang lain. Allah melarang seorang muslim untuk memiliki minuman keras dan babi, sebagaimana Allah melarang siapapun yang menjadi warga negara Islam untuk memiliki harta hasil riba dan perjudian. Tetapi Allah memberi izin untuk melakukan jual beli, bahkan menghalalkannya, disamping melarang dan mengharamkan riba. Allah membolehkan syirkah (baca: perseroan) model Inan, dan melarang perseroan model koperasi, perseroan saham, asuransi dan sebagainya.

Adapun kepemilikan yang disyari'atkan tersebut memiliki beberapa syarat. Sebagaimana memanage suatu kepemilikan itu juga disertai ketentuan-ketentuan, dimana kepemilikan tersebut tidak bisa lepas begitu saja dari kepentingan kelompok (comunity), serta individu sebagai bagian dari suatu comunity, bukan hanya sebagai individu yang terpisah sama sekali. Disamping itu, ia juga harus dilihat sebagai individu yang hidup dalam sebuah masyarakat (society) tertentu. Sementara untuk memanfaatkan zat tertentu yang menjadi hak milik, itu hanya bisa dilakukan karena adanya kekuasaan yang diberikan oleh As Syari' . Dengan kata lain, karena pada dasarnya kepemilikan tersebut adalah milik Allah, lalu Allah memberikan kepemilikan tersebut kepada seseorang, yang merupakan konsekuensi dari sebab-sebab yang mengikuti aturan syara', maka kepemilikan tersebut hakikatnya merupakan penyerahan hak milik atas barang tertentu dari As Syari' yang diberikan kepada seseorang dalam suatu kelompok (comunity), dimana kepemilikan tersebut tidak akan pernah ada, kalau bukan karena penyerahan kepemilikan --dari Allah (As Syari')-- tersebut. 
Hanya saja, kepemilikan atas suatu zat itu berarti kepemilikan atas zat barangnya sekaligus kegunaan (utility) zatnya, bukan hanya sekedar kepemilikan atas kegunaan (utility)-nya saja. Karena tujuan yang esensi dari adanya kepemilikan tersebut adalah pemanfaatan atas suatu zat dengan cara pemanfaatan tertentu yang telah dijelaskan oleh syara'.

Berdasarkan batasan kepemilikan individu (private propherty) tersebut, maka bisa difahami bahwa ternyata di sana ada sebab-sebab kepemilikan yang telah disyari'atkan. Disamping bisa difahami, bahwa di sana terdapat suatu managemen kepemilikan tertentu. Juga bisa difahami, bahwa ternyata di sana terdapat mekanisme tertentu untuk memanfaatkan suatu kepemilikan. Serta bisa difahami, bahwa di sana terdapat kasus-kasus yang dianggap bertentangan dengan hak milik individu (private propherty).

Demikianlah. Maka berdasarkan definisi di atas, bisa difahami makna yang hakiki tentang pemerolehan kekayaan yang telah diperbolehkan oleh Allah, serta makna usaha untuk memperoleh dan memanfaatkan kekayaan yang telah diperoleh. Dengan kata lain, definisi tersebut menjelaskan tentang makna yang hakiki tentang kepemilikan.

\section{Makna Kepemilikan}

Hak milik individu (private propherty) adalah hak syara' untuk seseorang, sehingga orang yang bersangkutan boleh memiliki kekayaan yang bergerak maupun kekayaan tetap. Hak ini akan bisa dijaga dan ditentukan dengan adanya pengundang-undangan hukum syara' dan 
pembinaan-pembinaan. Hak milik individu (private propherty) ini, disamping masalah kegunaan (utility)-nya yang tentu memiliki nilai finansial sebagaimana yang telah ditentukan oleh syara', ia juga merupakan otoritas yang diberikan kepada seseorang untuk memanage kekayaan yang menjadi hak miliknya. Sebagaimana ketika orang tersebut memiliki kekuasaan terhadap aktivitas yang bisa dia dipilih. Maka, apabila pembatasan hak milik tersebut sesuai dengan ketentuan perintah dan larangan Allah itu adalah sesuatu yang sangat wajar.

Batasan kepemilikan ini nampak pada sebab-sebab kepemilikan yang telah disyari'atkan, dimana dengan sebab-sebab tersebut, hak milik seseorang bisa diakui. Batasan kepemilikan tersebut juga nampak pada kondisi-kondisi yang menyebabkan sanksi tertentu, termasuk kondisi-kondisi yang tidak membawa konsekuensi sanksi apapun, seperti dalam kasus pencurian; kapan bisa disebut mencuri, juga seperti definisi salab (perampokan), ghashab (perampasan) dan seterusnya. Sebagaimana batasan tersebut juga nampak pada hak untuk melakukan transaksi terhadap suatu kepemilikan, serta kondisi-kondisi tertentu yang diperbolehkan melakukan transaksi, serta kondisi-kondisi yang dilarang untuk melakukan transaksi.

Disamping itu, batasan tersebut nampak pula pada definisi kondisi-kondisi tersebut berikut penjelasan tentang kasus-kasusnya. Maka, ketika Islam membatasi suatu kepemilikan, Islam tidak membatasinya dengan cara pemberangusan (perampasan), melainkan dengan menggunakan mekanisme tertentu. 
Adapun membatasi kepemilikan dengan menggunakan mekanisme tertentu itu nampak pada beberapa hal berikut ini:

1- Dengan cara membatasi kepemilikan dari segi cara-cara memperoleh kepemilikan dan pengembangan hak milik, bukan dengan merampas harta kekayaan yang telah menjadi hak milik.

2- Dengan cara menetukan mekanisme memanagenya.

3- Dengan cara menyerahkan tanah kharajiyah sebagai milik negara, bukan sebagai hak milik individu.

4- Dengan cara menjadikan hak milik individu (private propherty) sebagai milik umum (coletive propherty) dengan cara paksa, dalam kondisi-kondisi tertentu.

5- Dengan cara men- supplay orang yang memiliki keterbatasan faktor produksi, sehingga bisa memenuhi kebutuhannya sesuai dengan ketentuan-ketentuan yang ada.

Dengan demikian nampak jelaslah, bahwa makna kepemilikan individu (private propherty) itu adalah mewujudkan kekuasaan pada seseorang terhadap kekayaan yang dimilikinya dengan menggunakan mekanisme tertentu, sehingga menjadikan kepemilikan tersebut sebagai hak syara' yang diberikan kepada seseorang. Dimana, undang-undang telah menjadikan pemeliharaan hak milik individu tersebut sebagai kewajiban negara. Hak milik tersebut juga harus dihormati, dijaga serta tidak boleh diciderai. Oleh karena itu, 
dibuatlah sanksi-sanksi hukum yang bersifat preventif yang diberlakukan kepada siapa saja yang menciderai hak tersebut, baik karena mencuri, merampok, atau karena cara-cara lain yang tidak dibenarkan oleh syara'. Undang-undang ini juga menerapkan sanksi-sanksi hukum yang bersifat preventif kepada orang yang bersangkutan, serta dibuatlah pembinaan-pembinaan yang bersifat mendidik, untuk mencegah munculnya hal-hal yang bisa mendorong untuk memiliki salah satu hak milik yang bukan menjadi haknya, serta munculnya dorongan untuk memiliki hak milik orang lain. Sehingga, harta yang halal adalah harta yang diperoleh sesuai dengan makna kepemilikan tersebut. Sedangkan harta yang haram, adalah harta yang diperoleh tidak sesuai dengan maka kepemilikan tersebut, serta tidak layak disebut dengan makna milik.

\section{Sebab-Sebab Kepemilikan}

Harta (Mal) adalah apa saja yang bisa menjadi kekayaan, apapun bentuknya. Sedangkan yang dimaksud dengan sebab pemilikan harta adalah sebab yang menjadikan seseorang memiliki harta tersebut, yang sebelumnya tidak menjadi hak miliknya. Adapun barter teks aslinya berbunyi Mubadalah dengan berbagai bentuknya, tidak termasuk sebab-sebab pemilikan harta, melainkan sebab-sebab pemilikan zatnya. Sebab, barter merupakan pemilikan atas zat harta tertentu --yang ditukar-- dengan zat harta lain. Karena harta pada dasarnya bisa dimiliki, meskipun zatnya bisa saja saling ditukar. 
Begitu pula pengembangan harta, seperti keuntungan perdagangan, hasil sewa rumah, hasil mengairi tanaman, dan sebagainya tidak termasuk dalam katagori sebab-sebab pemilikan harta. Meskipun, semuanya bisa menyebabkan adanya beberapa harta yang lain, akan tetapi harta tersebut lahir dari harta lain, sehingga semuanya hanya merupakan sebab-sebab pengembangan harta, dan bukannya sebab-sebab pemilikan harta. Jadi, masalah pemilikan tersebut adalah masalah pemilikan harta baru, yaitu perolehan harta yang sebelumnya belum menjadi hak miliknya. Sehingga perbedaan antara sebab-sebab pemilikan dengan sebab-sebab pengembangan pemilikan itu adalah, bahwa sebab-sebab pemilikan merupakan perolehan harta yang sebelumnya belum menjadi miliknya, atau memperoleh harta yang belum dimiliki sebelumnya. Sedangkan sebab-sebab pengembangan pemilikan adalah memperbanyak kuantitas harta yang sebelumnya telah menjadi hak miliknya. Dimana, status harta tersebut memang sudah ada tinggal dikembangkan dan diperbanyak kuantitasnya.

Syara' telah menjelaskan masing-masing pemilikan dan pengembangan pemilikan tersebut dengan hukum-hukum yang berhubungan dengan masalahnya masing-masing. Transaksi, seperti jual-beli dan sewa-menyewa, adalah hukum-hukum yang berkaitan dengan pengembangan harta. Sedangkan bekerja, seperti berburu dan melakukan perseroan model mudlarabah adalah hukum-hukum yang berhubungan dengan sebab-sebab pemilikan. Maka sebab pemilikan, adalah sebab-sebab perolehan harta asal, yang sebelumnya belum dimiliki. Sedangkan sebab-sebab 
pengembangan pemilikan adalah sebab-sebab untuk memperbanyak kuantitas harta asal, yang pernah kita peroleh dengan salah satu sebab pemilikan.

Pemilikan atas harta tersebut memiliki sebab-sebab syar'i yang telah ditentapkan oleh Allah SWT dengan suatu sebab tertentu, yang tidak diperbolehkan melampaui batasan sebab-sebab tersebut. Sehingga, sebab pemilikan harta itu telah diatur dengan batasan yang telah dijelaskan oleh syara'. Sedangkan definisi pemilikan adalah hukum syara' yang ditentukan pada zat ataupun manfaat tertentu, itu mengharuskan adanya izin dari Allah sampai pemilikan tersebut bisa terwujud. Dengan begitu, ia mengharuskan adanya sebab-sebab yang diizinkan oleh Allah sampai pemilikan tersebut benar-benar ada. Sehingga, apabila sebab syar'i tersebut ada, maka pemilikan atas harta tersebut bisa terwujud. Sebaliknya, apabila sebab syar'i tersebut tidak ada, maka pemilikan atas harta tersebut tidak akan terwujud, meskipun harta tersebut secara de facto telah diperoleh. Sebab, pemilikan itu merupakan perolehan harta dengan salah satu sebab syar'i yang telah diizinkan oleh Allah.

Syara' telah menentapkan sebab-sebab pemilikan dalam suatu keadaan, yang telah dijelaskan dalam jumlah tertentu, dan bukannya dilepas begitu saja. Setelah itu, syara' menjadikan sebab-sebab pemilikan itu dalam bentuk garis-garis besar yang amat jelas, sehingga beberapa bagian yang merupakan cabang (furu') dan hukum-hukum dari garis-garis besar tersebut, bisa dimasukkan ke dalamnya. Dimana, garis-garis besar tersebut tidak disertai illat kulliyat tertentu, sehingga bentuk-bentuk yang lain --selain bentu-bentuk yang merupakan fakta hukumnya-- tidak bisa 
dianalogkan kepada garis-garis besar tersebut. Hal itu disebabkan karena kebutuhan-kebutuhan yang berkembang hanya terjadi terhadap barang-barang baru, dan bukannya terjadi pada mu'amalah. Dengan kata lain, tidak terjadi pada sistem interaksinya, melainkan pada barang yang dipergunakan. Oleh karena itu, mu'amalah harus dibatasi dengan kententuan khusus, yang bisa berlaku untuk kebutuhan-kebutuhan yang terus bermunculan dan beragam, termasuk untuk harta dilihat dari segi harta itu sendiri, serta tenaga dilihat dari segi tenaga itu sendiri. Dan dengan begitu, berarti pemilikan individu harus diatur dengan suatu mekanisme pemilikan, sehingga masyarakat bisa diselamatkan dari ancaman bahaya yang menjadi konsekuensi dari liberalisasi pemilikan individu. Karena pemilikan individu merupakan salah satu penampakan naluri mempertahankan diri (survivel instink), sebagaimana halnya dengan pernikahan yang merupakan penampakan naluri mempertahankan jenis/keturunan (sexual instink), maupun ibadah yang merupakan salah satu penampakan naluri beragama (religious instink).

Apabila penampakan-penampakan ini dibiarkan memenuhi tuntutan nalurinya sendiri-sendiri, maka pemenuhannya akan menyebabkan gejolak dan kegoncangan, sekaligus menyebabkan terjadinya pemenuhan yang ganjil dan salah. Oleh karena itu, mekanisme yang dipergunakan oleh manusia untuk mendapatkan harta itu harus ditetapkan --oleh Allah-- sehingga tidak hanya segelintir orang saja yang memiliki bargaining di tengah umat untuk mendapatkan harta tersebut, begitu pula tidak akan ada mayoritas orang yang dihalang-halangi untuk memenuhi 
sebagian kebutuhan mereka. Sehingga, harta tidak diperoleh untuk harta itu sendiri, hingga manusia tidak bisa merasakan kenikmatan hidup yang layak; serta harta tersebut tidak dilarang pula untuk diperoleh oleh orang lain hingga tetap tersimpan di dalam almari atau gudang. Oleh karena itu, sebab-sebab pemilikan tersebut harus ditetapkan.

Dengan mengkaji hukum-hukum syara' yang menentukan pemilikan seseorang atas harta tersebut, maka akan tampak bahwa sebab-sebab pemilikan itu terbatas hanya pada lima sebab berikut ini:

1- bekerja.

2- warisan.

3- kebutuhan akan harta untuk menyambung hidup.

4- harta pemberian negara yang diberikan kepada rakyat.

5- harta-harta yang diperoleh oleh seseorang dengan tanpa mengeluarkan harta atau tenaga apapun. 


\section{MEKANISME MEMANAGE HARTA}

\section{Hak Memanage}

Pemilikan telah didefiniskan sebagai suatu hukum syara' yang ditentukan pada zat benda atau kegunaan (utility) tertentu, yang memungkinkan siapa saja yang mendapatkannya untuk memanfaatkan barang tersebut, serta memperoleh kompensasi --baik karena barangnya diambil kegunaan (utility)-nya oleh orang lain, seperti disewa, ataupun karena dikonsumsi untuk dihabiskan zatnya, seperti dibeli-- dari barang tersebut. Oleh karena itu, pemilikan adalah hukum syara' yang ditentukan pada zat benda atau kegunaan (utility) tertentu. Dengan kata lain, pemilikan itu merupakan izin As Syari' .

Oleh karena itu, hak memanage tersebut sebenarnya merupakan konsekuensi dari hukum syara', yaitu konsekuensi dari adanya kebolehan bagi pemilik untuk memanfaatkan barang, dus memperoleh kompensasi karena adanya pemanfaatan tersebut. Jadi, hak memanage kepemilikan tersebut sebenarnya terikat dengan izin As Syari'. Sebab pemilikan itu hakikatnya merupakan izin As Syari' untuk suatu pemanfaatan. Maka, hak memanage itu juga berarti hak untuk memanfaatkan suatu zat barang.

Dan ketika harta itu merupakan milik Allah, sementara Allah telah menyerahkan kekuasaan atas harta tersebut kepada manusia, melalui izin dari-Nya, maka pemerolehan seseorang terhadap harta itu sama dengan kegiatan yang dilakukan oleh seseorang untuk memanfaatkan serta 
mengembangkan harta, yang antara lain adalah karena menjadi hak miliknya. Sebab, ketika seseorang memiliki harta, maka dia esensinya memiliki harta tersebut hanya untuk dimanfaatkan. Sehingga dalam hal ini, dia terikat dengan hukum-hukum syara', bukan bebas memanage secara mutlak. Sebagaimana dia tidak bisa bebas memanage zat barang itu sendiri secara mutlak, meskipun ia memiliki zatnya. Alasannya adalah, bahwa kalau dia memanage untuk memanfaatkan harta tersebut dengan cara yang tidak sah menurut syara', misalnya dengan menghambur-hamburkannya, Teks asalnya berbunyi safhi . Safhi adalah tindakan menghambur-hamburkan harta, tanpa kendali. Safiih adalah sebutan bagi orang yang melakukan safhi . Dalam Islam, orang semacam ini tidak boleh dibiarkan memanage hartanya sendiri, tetap harus diangkat seorang washi yang bertugas untuk memanage hartanya, sampai orang yang bersangkutan bisa normal dan bisa memanage hartanya dengan baik, pent. atau mempergunakannya untuk suatu kemaksiatan, maka negara wajib mengawalnya, dan melarangnya untuk memanage, dus merampas wewenang yang telah diberikan oleh negara kepadanya.

Oleh karena itu, memanage dan memanfaatkan suatu zat benda itulah yang merupakan makna yang dimaksud dari adanya pemilikan zat benda tersebut, atau itulah yang merupakan akibat dari adanya pemilikan tersebut. Sehingga hak memanage suatu zat benda yang dimiliki itu juga mencakup hak untuk memanagenya dalam rangka mengembangkan kepemilikan benda tersebut, termasuk hak untuk memanagenya dengan cara menafkahkan, baik karena hubungan --seperti hadiah, hibbah, dan wasiat-- maupun 
karena menjadi suatu nafkah --seperti ayah terhadap anaknya.

\section{Pengembangan Kepemilikan}

Pengembangan harta itu terikat dengan uslub dan faktor produksi yang dipergunakan untuk menghasilkan harta. Sedangkan pengembangan kepemilikan harta itu terkait dengan suatu mekanisme yang dipergunakan oleh seseorang untuk menghasilkan pertambahan kepemilikan tersebut. Oleh karena itu, sebenarnya sistem ekonomi itu tidak membahas tentang pengembangan harta, melainkan hanya membahas tentang pengembangan kepemilikannya. Islam juga tidak pernah mengemukakan tentang pengembangan harta, bahkan menyerahkan masalah pengembangan harta tersebut kepada individu agar mengembangkannya dengan uslub dan faktor produksi apa saja yang menurutnya layak dipergunakan untuk mengembangkan harta tersebut.

Sementara itu, Islam mengemukakan masalah pengembangan kepemilikan harta, dus menjelaskan hukum-hukumnya. Dari sinilah, maka pengembangan kepemilikan itu haruslah terikat dengan hukum-hukum tertentu yang telah dibuat oleh As Syari', dan tidak boleh melampauinya. As Syari' juga telah menjelaskan garis-garis besar tentang mekanisme yang dipergunakan untuk mengembangkan kepemilikan tersebut, lalu menyerahkan detailnya kepada para mujtahid agar mereka menggali hukum-hukumnya, sesuai dengan pemahaman terhadap fakta yang ada, serta pemahaman terhadap nash yang 
menjelaskan tentang mekanisme tertentu yang mengharamkan dan melarangnya, dari garis-garis besar tersebut. Maka, As Syari' telah menjelaskan mu'amalah dan transaksi-transaksi yang dipergunakan untuk mengembangkan kepemilikan tersebut, dus melarang seseorang untuk mengembangkan kepemilikan tersebut dengan suatu mekanisme yang khas.

Bagi orang yang meneliti harta-harta yang ada di dalam kehidupan dunia ini, maka --setelah melakukan penelitian tersebut-- pasti akan menemukan bahwa harta itu hanya ada tiga macam, yaitu tanah, harta yang diperoleh melalui pertukaran dengan barang, serta harta yang diperoleh melalui perubahan bentuknya dari satu bentuk menjadi berbagai bentuk yang lain. Dari sinilah, maka sesuatu yang lazim dipergunakan oleh orang untuk menghasilkan harta atau mengembangkannya adalah pertanian, perdagangan dan industri. Jadi, mekanisme untuk meningkatkan pemilikan seseorang atas harta inilah yang menjadi topik pembahasan di dalam sistem ekonomi. Sedangkan pertanian, perdagangan dan industri adalah uslub dan faktor produksi yang dipergunakan untuk menghasilkan harta. Jadi, hukum-hukum yang terkait dengan pertanian, perdagangan dan industri itulah yang sebenarnya menjelaskan tentang mekanisme yang dipergunakan oleh seseorang untuk mengembangkan kepemilikannya atas harta tersebut.

Syara' telah menjelaskan hukum-hukum pertanian, ketika menjelaskan hukum-hukum tanah serta hal-hal yang terkait dengan hukum-hukum tersebut. Syara' juga telah menjelaskan hukum-hukum perdagangan, ketika menjelaskan hukum-hukum jual beli, perseroan serta hal-hal yang terkait 
dengan hukum-hukum tersebut. Syara' juga telah menjelaskan tentang industri, ketika menjelaskan hukum-hukum tentang ajiir dan produksi. Sedangkan tentang hasil produksi atau barang-barang yang dihasilkannya, itu adalah termasuk dalam masalah perdagangan. Oleh karena itu, pengembangan kepemilikan tersebut terikat dengan hukum-hukum yang telah dibawa oleh syara', yaitu hukum-hukum tanah serta masalah-masalah yang terkait dengan hukum-hukum tersebut, hukum-hukum jual-beli, perseroan serta masalah-masalah yang terkait dengan hukum-hukum tersebut, serta hukum-hukum tentang ajiir dan produksi.

\section{Hukum-Hukum Tanah}

Setiap jenis tanah mempunyai lahan sekaligus memiliki kegunaan (utility). Lahan adalah zat tanahnya itu sendiri, sedangkan kegunaan (utility) adalah penggunaannya, misalnya untuk pertanian dan sebagainya. Islam telah memperbolehkan memiliki lahan dan kegunaan (utility)-nya. Islam juga menentukan hukum bagi masing-masing kepemilikan --baik lahan maupun kegunaan (utility)-nya. Adapun tentang kepemilikan lahan tanah itu memang harus diteliti terlebih dahulu: Apabila negara, termasuk diantaranya adalah tanah setempat, telah ditaklukkan melalui peperangan secara paksa, maka lahan tanah tersebut adalah menjadi milik negara. Tanah tersebut dianggap sebagai tanah kharajiyah, selain jazirah Arab.

Apabila negara, termasuk diantaranya adalah tanah setempat, telah ditaklukkan dengan damai, maka harus 
diteliti terlebih dahulu: Apabila perdamaian tersebut telah menyepakati, bahwa tanah tersebut adalah milik kita (baca: kaum muslimin), dan kita membiarkan penduduknya untuk menempatinya dengan catatan mereka harus membayar kharaj sebagai kompensasinya, maka kharaj ini berlaku selama-lamanya atas tanah tersebut. Dan, tanahnya tetap menjadi tanah kharajiyah hingga hari kiamat, meskipun tanah tersebut telah ditranfer kepada kaum muslimin karena masuk Islam, dibeli ataupun dengan cara lain.

Apabila perdamaian tersebut telah menyepakati, bahwa tanah tersebut adalah milik mereka (baca: kaum kuffar), serta tetap menjadi milik mereka, dan mereka ditetapkan di sana dengan keharusan membayar kharaj tertentu yang diambil sebagai kewajiban mereka, maka kharaj tersebut statusnya adalah sama dengan jizyah. Dimana kharaj tersebut akan gugur, kalau mereka masuk Islam, atau menjual tanah tersebut kepada orang Islam. Akan tetapi kalau mereka menjual tanah tersebut kepada orang kafir, maka kharaj tersebut tetap berlaku dan tidak gugur sebagai kewajiban mereka. Sebab orang kafir memang layak untuk membayar kharaj dan jizyah.

Apabila negeri tersebut penduduknya terlebih dahulu memeluk Islam, seperti Indonesia atau jazirah Arab, maka lahan tanah tersebut adalah milik penduduk setempat. Dan status tanahnya adalah tanah usyriyah. Alasannya adalah karena status tanah itu sama dengan harta, sehingga bisa dianggap sebagai ghanimah yang didapatkan dalam peperangan. Jadi, hukumnya halal dan menjadi milik baitul mal. Hafash Bin Ghuyats dari Abi Dza'bi dari Az Zuhri yang mengatakan: "Rasulullah SAW telah menerima jizyah dari 
orang Majusi Bahrain." Az Zuhri mengatakan: "Siapa saja di antara mereka yang memeluk Islam, maka keislamannya bisa diterima dan keselamatan dirinya serta hartanya akan dilindungi, selain tanah. Sebab tanah adalah harta rampasan --yang menjadi hak-- bagi kaum muslimin, apabila sejak awal dia tidak memeluk Islam, maka ia tetap dilarang (memilikinya)."

Perbedaan antara tanah dengan harta ghanimah yang lain adalah, bahwa harta ghanimah yang lain bisa dibagi, dimanage dan diberikan kepada seseorang, sedangkan tanah itu lahannya tetap secara de jure dimanage oleh baitul mal . Namun, tanah tersebut tetap bisa dimanfaatkan oleh penduduk setempat. Tentang status tanah yang tetap menjadi milik baitul mal dan lahannya tidak dapat dibagi, selain bisa dimanfaatkan oleh penduduk setempat, itu nampak dari status tanah tersebut sebagai harta rampasan umum bagi seluruh kaum muslimin, baik mereka yang hidup pada masa penaklukan ataupun genarasi pasca mereka.

Sedangkan status tanah jazirah Arab, semuanya adalah usyriyah. Sebab, Nabi SAW telah menaklukkan Makkah dengan paksa, lalu membiarkan tanahnya untuk penduduknya, tanpa dibebani untuk membayar kharaj . Sebab, status kharaj tanah itu sama dengan jizyah, yaitu untuk orang, padahal kharaj tanah Arab tersebut tidak ditetapkan, sama seperti tidak ditetapkannya jizyah untuk lahan-lahan mereka. Karena apabila kharaj diberlakukan atas suatu negeri, maka penduduk negeri setempat, berikut apa yang menjadi keyakinan mereka serta apa yang menjadi sesembahan mereka, tetap akan dibiarkan, sebagaimana 
yang terjadi di daerah Sawad-Irak. Dimana orang-orang musyrik Arab, ketika itu, tidak ada pilihan lain selain memeluk Islam atau pedang. Allah SWT berfirman:

"Apabila sudah habis bulan-bulan Haram itu, maka bunuhlah orang-orang musyrikin itu di mana saja kamu jumpai mereka, dan tangkaplah mereka. Kepunglah mereka dan intailah di tempat pengintaian. Jika mereka bertaubat dan mendirikan shalat dan menunaikan zakat, maka berilah kebebasan kepada mereka untuk berjalan." (Q.S. At Taubah: 5)

"Kamu akan diajak untuk (memerangi) kaum yang mempunyai kekuatan besar, kamu akan memerangi mereka atau mereka menyerah (masuk Islam)." (Q.S. Al Fath: 16)

Selama mereka tidak dipungut jizyah, maka tanah mereka juga tidak akan dipungut kharaj .

Oleh karena itu, lahan tanah di tiap-tiap negeri yang telah ditaklukkan oleh Islam dengan paksa atau damai, dengan perjanjian bahwa tanah tersebut menjadi milik kita (kaum muslimin), maka tanah tersebut adalah milik negara dan dianggap sebagai tanah kharajiyah, baik tanah tersebut tetap dikuasai oleh umat Islam seperti Mesir, Irak dan Turki, ataupun yang kini dikuasai oleh orang-orang kafir seperti Spanyol, Ukrania, Albania, India, Yugoslavia dan sebagainya. Sedangkan tanah yang penduduknya terlebih dahulu memeluk Islam, seperti Indonesia dan seluruh tanah di jazirah Arab adalah milik penduduk setempat dan disebut dengan tanah usyriyah. 
Adapun kegunaan (utility) tanah adalah bagian dari hak milik individu (private propherty), baik status tanahnya kharajiyah maupun usyriyah ; baik diberikan secara cuma-cuma oleh negara kepada mereka, atau karena hasil pertukaran dengan sesama mereka, atau karena mereka yang menghidupkannya ataupun karena mereka yang memagarinya. Kegunaan (utility) ini telah memberikan hak-hak yang yang sama kepada pemanagenya, seperti hak-hak yang diberikan kepada pemilik lahannya. Sehingga, dia berhak menjualnya, atau menghibahkan atau mewariskannya. Sebab negara berhak memberikan tanah-tanah tersebut kepada individu, baik status tanah tersebut usyriyah ataupun khirajiyah. Hanya bedanya, kalau yang diberikan tersebut adalah tanah khirajiyah, berarti yang dimiliki hanya kegunaan (utility) tanah tersebut, sedangkan lahannya tetap menjadi milik baitul mal. Sementara kalau yang diberikan adalah tanah usyriyah, maka yang dimiliki adalah lahan sekaligus kegunaan (utility)-nya.

Perbedaan antara usyur dengan kharaj adalah, bahwa usyur itu merupakan hasil tanah, yaitu pungutan yang diambil oleh negara dari pengelola tanah sebesar $1 / 10$ dari hasil panen riil, apabila tanamannya diairi dengan air tadah hujan, dengan pengairan alami. Dan negara akan mengambil $1 / 20$ dari hasil panen riil, apabila tanamannya diairi oleh orang atau yang lain dengan pengairan teknis (buatan). Imam Muslim meriwayatkan dari Jabir yang mengatakan: Nabi SAW bersabda: 
"(Tanaman) apa saja yang diairi oleh bengawan dan hujan (harus dimabil) 1/10 (dari hasil panennya). Dan apa saja yang diairi dengan kincir air, maka (harus diambil) 1/20 (dari hasil panennya)."

Usyur ini dianggap sebagai zakat dan diserahkan kepada baitul mal, serta tidak dibagikan kecuali kepada delapan ashnaf (kelompok) yang telah disebutkan di dalam ayat: "Sesungguhnya zakat itu hanya untuk para fakir, miskin ...." (Q.S. At Taubah: 60).

Al Hakim, Al Baihaqi dan At Thabrani telah mengeluarkan hadits dari Abu Musa dan Mu'adz ketika Nabi SAW mengutus mereka berdua ke Yaman, agar mereka berdua mengajari penduduk di sana tentang masalah agama mereka. Beliau SAW bersabda:

"Janganlah kalian mengambil shadaqah, selain dari empat jenis (buah-buahan), yaitu: sya'ir, hinthah, zabib (anggur) dan tamr (kurma)."

Sedangkan kharaj tanah adalah harta yang diambil oleh negara dari pemilik tanah setempat, dengan kadar tertentu yang telah ditentukan dan dibatasi oleh negara, yang umumnya sesuai dengan perkiraan penghasilan tanah, bukan penghasilan riilnya. Tanah tersebut diperkirakan berdasarkan kandungannya, sehingga pemilik tanah setempat serta baitul 
mal tidak terdzalimi. Dan kharaj tersebut dipungut dari pemilik tanah, setahun sekali, baik tanah tersebut ditanami ataupun tidak, baik tanah tersebut subur ataupun kering. "Umar Bin Khattab r.a. pernah mengirim Utsman Bin Hanif ke Sawad, dan memerintahkannya agar memungut (kharaj atas) tanah tersebut. Umar menetapkan untuk tiap satu jarib, baik yang ditempati ataupun ditanami termasuk yang bisa disamakan dengannya, (kharajnya) adalah sebesar satu dirham dan satu qafiz." Riwayat ini dikeluarkan oleh Abu Yusuf di dalam kitab Al Kharaj dari Amru Bin Maimun dan Haritsah Bin Mudhrib. Al Hajjaj Bin Arthi'ah menceritakan dari Amru Bin Auf:

"Bahwa Umar Bin Khattab r.a. pernah memungut (kharaj) tanah Sawad, selain gunung Halwan. Lalu dia menetapkan untuk tiap satu jarib, baik yang ditempati ataupun yang ditanami, yang mendapatkan air dengan timba ataupun dengan yang lain, yang ditanami atau yang dibiarkan, adalah sebesar satu dirham dan satu qafiz."

Riwayat ini dikeluarkan oleh Abu Yusuf di dalam kitab Al Kharaj . Kharaj tersebut tempatkan di baitul mal pada bagian selain bagian zakat. Kemudian dibagikan untuk seluruh bagian yang sesuai dengan kebijakan negara, sebagaimana harta kekayaan yang lain.

Tanah yang telah ditaklukkan dengan cara paksa dan diambil kharaj -nya, maka kharaj tersebut tetap sepanjang masa. Apabila penghuni tanah tersebut memeluk Islam atau menjualnya kepada orang Islam, maka kharaj-nya tetap tidak akan gugur. Karena sifat tanah tersebut sebagai tanah yang 
ditaklukkan akan tetap hingga akhir zaman. Mereka juga wajib membayar usyur selain membayar kharaj. Sebab kharaj adalah hak yang diwajibkan atas tanah, sedangkan usyur adalah hak yang diwajibkan atas pengelola tanah yang muslim, berdasarkan ayat-ayat dan hadits-hadits yang ada. Dan tidak ada kontradiksi antara kedua hak tersebut, sebab keduanya sama-sama wajib karena adanya dua sebab yang berbeda. Sementara apa yang dijadikan argumentasi oleh mazhab Imam Abu Hanifah, bahwa antara usyur dengan kharaj tidak bisa bersama-sama, yaitu hadits yang mereka riwayatkan dari Rasulullah SAW:

"Tidak akan pernah bertemu, antara usyur dengan kharaj dalam satu tanah seorang muslim."

Ini adalah bukan hadits, bahkan tidak satu al hafidz pun yang menetapkan bahwa riwayat di atas merupakan pernyataan Rasulullah SAW.

Kharaj harus dikeluarkan terlebih dahulu. Apabila setelah kharajnya dikeluarkan, namun hartanya masih cukup untuk membayar kewajiban zakat tanaman dan buah-buahan, semisal masih mencapai satu nishab, maka zakat tersebut harus dikeluarkan. Namun bila sisanya tidak mencapai satu nishab, maka tidak wajib zakat. 


\section{Menghidupkan Tanah Mati}

Tanah mati adalah tanah yang tidak nampak dimiliki oleh seseorang, serta tidak nampak ada bekas-bekas apapun, seperti pagar, tanaman, pengelolaan, ataupun yang lain. Menghidupkan tanah mati (ihya'ul mawat) itu artinya mengelola tanah tersebut, atau menjadikan tanah tersebut layak untuk ditanami dengan seketika. Tiap tanah mati, apabila telah dihidupkan oleh orang, maka tanah tersebut telah menjadi milik orang yang bersangkutan. Syara' telah menjadikan tanah tersebut sebagai milik orang yang menghidupkannya, berdasarkan hadits yang diriwayatkan oleh Imam Bukhari dari Aisyah bahwa Rasulullah SAW pernah bersabda:

"Siapa saja yang telah mengelola sebidang tanah, yang bukan menjadi hak orang lain, maka dialah yang lebih berhak."

Imam Abu Dawud telah meriwayatkan, bahwa Nabi SAW telah bersabda:

"Siapa saja yang telah memagari sebidang tanah dengan pagar, maka tanah itu adalah miliknya."

Imam Bukhari juga meriwayatkan hadits dari Umar dari Rasulullah SAW, bahwa beliau SAW bersabda:

"Siapa saja yang telah menghidupkan sebidang tanah mati, maka tanah itu adalah hak miliknya." 
Jadi, baik muslim maupun kafir dzimmi adalah sama, karena hadits tersebut bersifat mutlak.

Menghidupkan tanah (ihya'ul mawat) itu berbeda faktanya dengan pemberian cuma-cuma (iqtha'). Perbedaannya adalah, bahwa ihya'ul mawat itu berhubungan dengan tanah mati, yang tidak nampak dimiliki oleh seseorang, juga tidak nampak adanya bekas-bekas apapun, seperti pagar, tanaman, pengelolaan ataupun yang lain. Ihya'ul mawat itu artinya mengelola tanah tersebut dengan sesuatu yang menunjukkan bahwa tanah tersebut dikelola. Sedangkan iqtha' itu adalah memberikan tanah yang sudah dikelola dan layak ditanami, dengan seketika, atau tanah yang nampak sebelumnya telah dimiliki oleh seseorang.

Sedangkan tahjir (baca: memagari tanah) itu statusnya sama dengan menghidupkan tanah. Hal itu didasarkan kepada sabda Rasulullah SAW:

"Siapa saja yang telah memagari sebidang tanah dengan pagar, maka tanah itu adalah miliknya."

"Siapa saja yang terlebih dahulu sampai pada suatu tempat yang belum pernah didahului oleh seorang muslim pun, maka dialah yang lebih berhak atas tempat tersebut." 
Juga karena dengan memagari tanah telah menjadikan orang yang memagarinya memiliki hak untuk memanagenya, berdasarkan nash hadits di atas. Begitu pula, orang yang memagarinya berhak melarang orang lain yang menginginkan untuk menghidupkan tanah yang sudah dipagarinya. Apabila orang tersebut memaksa, lalu dia menghidupkan tanah yang sudah dipagari orang tersebut, maka orang tersebut tetap tidak berhak memilikinya, dan tanah tersebut harus dikembalikan kepada orang yang memagari sebelumnya. Sebab, memagari itu statusnya sama dengan menghidupkan, yaitu berhak memanage tanah tersebut serta menguasainya. Apabila orang yang memagari tanah tersebut menjualnya, maka dia berhak mendapatkan harga dari hasil penjualannya. Sebab hal itu merupakan hak yang dikompensasi dengan harta tertentu, sehingga dia juga diperbolehkan untuk melakukan pertukaran atas tanah tersebut. Apabila orang yang memagari tersebut telah meninggal, maka pemilikannya bisa diwarisi oleh ahli warisnya, sebagaimana pemilikan-pemilikan yang lain. Mereka juga bisa memanagenya, dus akan dibagikan kepada mereka sesuai dengan ketentuan syara', sebagaimana pembagian harta-harta yang lain.

Yang dimaksud dengan memagari itu, bukan berarti meletakkan batu di atasnya, akan tetapi yang dimaksud adalah meletakkan apa saja yang bisa menunjukkan bahwa tanah tersebut menjadi kekuasaannya, atau miliknya. Sehingga memagari tanah itu bisa jadi dengan meletakkan batu di atas batas-batas tanah tersebut. Bisa jadi menggunakan selain batu, seperti menancapkan potongan dedahanan yang masih segar di sekeliling tanah tersebut, 
atau dengan membersihkan tanah tersebut, atau membakar duri yang ada di sana, ataupun memangkas rumput dan duri yang ada, serta menancapkan duri-duri di sekelilingnya agar orang yang ingin masuk tidak bisa, atau dengan menggali kali-kalinya dan tidak mengairinya, ataupun hal-hal lain yang serupa, maka semuanya itu termasuk dalam katagori memagari tanah.

Nampak dari hadits di atas, bahwa memagari tanah dus menghidupkannya adalah hanya berlaku untuk tanah mati, bukan tanah yang lain. Pernyataan Umar: "Orang yang memagari tanah tidak berhak (atas tanah yang telah dipagarinya) setelah (membiarkannya) selama tiga tahun." adalah orang yang memagari tanah mati. Sedangkan tanah yang tidak mati, maka tidak bisa dimiliki dengan cara memagari, serta bukan dengan cara menghidupkannya, melainkan dengan cara pemberian cuma-cuma dari imam (khalifah). Sebab, menghidupkan tanah dan memagarinya telah dinyatakan hanya untuk tanah mati. Rasulullah SAW bersabda: "Siapa saja yang menghidupkan tanah mati." Mati adalah sifat, sehingga mafhum mukhalafah- nya bisa dipergunakan. Maka, mati itu merupakan qayyid (penentu). Disamping itu, ada riwayat dari Al Baehaqi dari Amru Bin Syu'aib, bahwa Umar telah menjadikan tahjir dengan batas waktu tiga tahun, apabila tanah tersebut dibiarkan hingga lewat waktu tiga tahun, kemudian tanah tersebut dihidupkan oleh orang lain, maka dialah yang lebih berhak. Hal itu juga bisa diartikan, bahwa selain tanah mati tidak boleh dipagari serta tidak boleh dihidupkan.

Perbedaan antara tanah mati dengan tanah yang tidak mati ini menunjukkan, bahwa Rasulullah SAW telah 
memubahkan kepada individu untuk memiliki tanah mati tersebut dengan cara menghidupkan dan memagarinya, sehingga hal itu merupakan salah satu kemubahan. Oleh karena itu, untuk menghidupkan dan memagarinya tidak perlu izin dari imam (khalifah). Sebab perkara-perkara yang dimubahkan tidak perlu minta izin dari imam (khalifah). Sedangkan tanah-tanah yang tidak mati, itu tidak bisa dimiliki kecuali bila tanah tersebut diberikan secara cuma-cuma oleh imam (khalifah), sebab hal itu tidak termasuk hal-hal yang mubah, melainkan hal-hal yang telah menjadi otoritas imam. Itulah yang kemudian disebut dengan sebutan tanah-tanah milik negara. Hal itu ditunjukkan oleh kasus Bilal Al Muzni yang meminta sebidang tanah dengan cuma-cuma kepada Rasulullah SAW, dimana dia tidak bisa memilikinya hingga tanah tersebut diberikan oleh beliau kepadanya. Kalau seandainya dia bisa memiliki dengan cara menghidupkan dan memagarinya, karena dia telah memagarinya dengan suatu tanda yang bisa menunjukkan pemilikannya atas tanah tersebut, tentu tanah tersebut bisa dia miliki tanpa harus meminta Rasul agar beliau memberikannya.

Siapa saja yang menghidupkan sebidang tanah mati di atas tanah usyriyah, maka dia bisa memiliki lahan dan kegunaan (utility)-nya sekaligus, baik muslim maupun non muslim. Bagi seorang muslim wajib membayar usyur dari panen tanaman dan buah-buah sebagai zakat yang diwajibkan atas tanaman dan buah-buahan tersebut, apabila telah mencapai satu nishab. Sementara seorang non muslim tidak wajib membayar zakat, baik usyur maupun kharaj . Sebab, orang non muslim bukan orang yang wajib membayar 
zakat, sehingga dia bisa diwajibkan. Disamping karena kharaj itu tidak diwajibkan atas tanah usyur.

Siapa saja yang menghidupkan sebidang tanah mati di atas tanah kharajiyah, yang belum pernah ditarik kharajnya, maka dia berhak memiliki lahan dan kegunaan (utility)-nya sekaligus, bila dia seorang muslim; dan hanya berhak memiliki kegunaan (utility)-nya, apabila dia orang non muslim. Bagi seorang muslim, hanya wajib membayar usyur dan tidak wajib membayar kharaj. Sedangkan bagi orang non muslim wajib membayar kharaj, sebagaimana yang telah ditetapkan untuk penduduk tanah yang non muslim, ketika mereka dibiarkan pada saat penaklukkan, sebagai kompensasi kharaj yang harus mereka keluarkan.

Siapa pun yang telah menghidupkan sebidang tanah mati, di atas tanah kharaj yang sebelumnya pernah ditetapkan kharaj- nya sebelum tanah tersebut berubah menjadi tanah mati, maka orang yang bersangkutan hanya berhak memiliki kegunaan (utility)-nya, bukan lahannya, baik muslim maupun non muslim. Maka, masing-masing tetap diwajibkan membayar kharaj, sebab tanah tersebut berstatus sebagai tanah yang ditaklukkan yang harus diambil kharaj-nya. Oleh karena itu, kharaj tersebut tetap wajib atas tanah tadi sepanjang masa, baik tanah tadi dimiliki oleh seorang muslim maupun non muslim.

Ini adalah ketentuan menghidupkan tanah untuk ditanami. Adapun tanah yang ditempati, atau dipakai membangun industri, atau tempat-tempat penampungan, maka tanah tersebut tidak dikenakan usyur maupun kharaj . Dalam hal ini tidak ada bedanya antara tanah usyriyah dengan tanah kharajiyah. Sebab, para sahabat yang telah 
menaklukkan tanah Irak dan Mesir telah menguasai Kufah, Basrah dan Fisthath (Cairo Lama). Mereka telah mendudukinya pada masa Umar Bin Khattab, dan bersama mereka tinggal pula orang lain (non muslim), namun mereka tidak dipungut kharaj dan tidak diharuskan membayar zakat atas tempat tinggal mereka. Sebab, zakat tersebut tidak diwajibkan atas perumahan dan bangunan.

\section{Memanage Tanah}

Tiap orang yang memiliki tanah akan dipaksa untuk mengelola tanahnya secara optimal. Bagi siapa saja yang membutuhkan (biaya perawatan) akan diberi sesuatu (modal) dari baitul mal, sehingga memungkinkan orang yang bersangkutan untuk mengelola secara optimal. Namun, apabila orang yang bersangkutan mengabaikannya selama tiga tahun, maka tanah tersebut akan diambil dan diberikan kepada yang lain. Umar Bin Khattab ra. mengatakan: "Orang yang memagari tanah tidak berhak (atas tanah yang telah dipagarinya) setelah (membiarkannya) selama tiga tahun." Yahya Bin Adam meriwatkan melalui sanad Amru Bin Syu'aib mengatakan: "Rasulullah SAW telah memberi sebidang tanah kepada beberapa orang dari Muzainah atau Juhainah, kemudian mereka mengabaikannya, lalu ada suatu kaum menghidupkannya. Umar berkata: 'Kalau seandainya tanah tersebut pemberian dariku, atau dari Abu Bakar, tentu aku akan mengembalikannya, akan tetapi dari Rasulullah SAW.'" Dia (Amru Bin Syu'aib) berkata: "Umar mengatakan: 'Siapa saja yang mengabaikan tanah selama tiga tahun, yang tidak 
dia kelola, lalu ada orang lain mengelolanya, maka tanah tersebut adalah miliknya.'" Maksudnya, tanah tersebut telah lewat tiga tahun lebih. Artinya kalau tanah tersebut dari Abu Bakar, tentu tidak akan sampai lebih tiga tahun, atau kalau dari aku tentu juga tidak akan sampai lebih tiga tahun, akan tetapi tanah tersebut dari Rasulullah, sementara waktunya telah lewat dari tiga tahun, maka tidak mungkin dicabut kembali.

Abu Ubaid telah mengeluarkan sebuah riwayat di dalam kitab Al Amwal dari Bilal Bin Al Harits Al Muzni: "Bahwa Rasulullah SAW telah memberikan lembah secara keseluruhan." Dia (Abu Ubaid) berkata: Maka, pada masa Umar, dia berkata kepada Bilal: "Bahwa Rasulullah SAW tidak memberikan (lembah) itu kepadamu untuk kamu pagari agar orang-orang tidak bisa mengambilnya, akan tetapi beliau memberikan kepadamu agar kamu menggarapnya. Maka, ambillah dari tanah tersebut yang sanggup kamu kelola, dan yang lain (yang tidak bisa kamu kelola) kamu kembalikan." ljma' sahabat juga telah sepakat bahwa siapa saja yang mengabaikan tanahnya selama tiga tahun, maka tanah tersebut harus diambil dari pemilik asalnya, lalu diberikan kepada yang lain.

Oleh karena itu, seorang pemilik tanah boleh menanami tanahnya dengan alatnya, benihnya, hewan dan pekerja-pekerjanya. Dia juga boleh mempekerjakan para pekerja untuk menanaminya. Apabila dia tidak mampu untuk mengusahakannya, maka dia akan dibantu oleh negara. Namun, apabila tanah tersebut tidak ditanami oleh pemiliknya, maka tanah tersebut akan diberikan kepada orang lain sebagai pemberian cuma-cuma, tanpa kompensasi 
apapun, sehingga dia menggarapnya. Apabila pemiliknya tidak menggarapnya dan tetap menguasainya, maka dibiarkan selama tiga tahun. Apabila tanah tersebut dibiarkan --tanpa dikelola-- selama tiga tahun, maka negara akan mengambil tanah tersebut dari pemiliknya dan diberikan kepada yang lain.

Yunus menceritakan dari Muhammad Bin Ishaq dari Abdullah Bin Abu Bakar berkata: "Bilal Bin Al Harits Al Muzni datang kepada Rasulullah SAW, lalu dia meminta sebidang tanah kepada beliau. Beliau lalu memberikan tanah tersebut dengan ukuran panjang dan lebar kepadanya." Ketika Bilal dipimpin oleh khalifah Umar, dia (Umar) berkata kepadanya: "Wahai Bilal, engkau telah meminta sebidang tanah yang panjang dan lebar kepada Rasulullah SAW. Lalu beliau memberikannya kepadamu. Dan Rasulullah SAW tidak pernah menolak sama sekali untuk dimintai, sementara engkau tidak mampu (menggarap) tanah yang ada di tanganmu." Bilal menjawab: "Benar." Umar berkata: "Lihatlah, mana di antara tanah itu yang mampu kamu garap, maka milikilah. Dan mana yang tidak mampu kamu garap, serahkanlah kepada kami, dan kami akan membagikannya kepada kaum muslimin." Bilal berkata: "Demi Allah, aku tidak akan melakukan sama sekali dan memberikan apa yang diberikan oleh Rasulullah SAW." Umar berkata: "Demi Allah, engkau hendaknya benar-benar menggarapnya." Kemudian Umar mengambil tanah yang tidak mampu dia garap dari Bilal, lalu dia membagikan kepada kaum muslimin. Hadits ini diriwayatkan oleh Yahya Bin Adam di dalam kitab Al Kharaj. Hadits ini tegas menjelaskan, bahwa apabila pemilik tanah tersebut tidak mampu menggarap tanahnya dan 
membiarkannya selama tiga tahun, maka tanah tersebut akan diambil oleh negara dari pemiliknya dan diberikan kepada orang lain, sebagaimana yang telah dilakukan oleh Umar Bin Khattab kepada Bilal Al Muzni terhadap tambang yang dimiliki oleh kabilahnya --yang terletak di sebelah Fara' di daerah Hijaz.

Washasil, tanah itu bisa dimiliki dengan memagari (tahjir); bisa dengan diberikan secara cuma-cuma (iqtha') oleh khalifah; bisa juga dengan menghidupkannya; bisa dengan waris, dan bisa pula dengan dibeli. Sedangkan nash-nash yang menyebutkan tentang pencabutan tanah dari orang yang membiarkannya selama tiga tahun adalah nash-nash yang menyebut muhtajir dan orang yang diberi oleh khalifah dengan cuma-cuma, sementara nash-nash yang menyebutkan selain dua pemilik tanah tersebut tidak ada, misalnya orang yang menerima dari waris, atau orang yang menghidupkan, maupun orang yang membeli, apakah berarti tiap tanah yang dibiarkan oleh pemilik tanah selama tiga tahun tersebut, boleh diambil oleh khalifah kemudian diberikan kepada orang lain, ataukah pencabutan itu hanya berlaku bagi muhtajir dan orang yang diberi oleh khalifah dengan cuma-cuma?

Jawabnya adalah, bahwa orang yang memperhatikan muhajjir (baca: orang yang memagari) akan melihat bahwa pemagaran tanah tersebut statusnya sama dengan membeli, atau mewarisi, ataupun sebab-sebab yang lain. Jadi, dia telah memiliki tanah tersebut untuk dimanage dan dikuasai. Apabila orang yang memagari tadi menjual tanah yang telah dia pagari, maka dia berhak mendapatkan harga penjualannya. Sebab, hal itu adalah hak yang telah 
dikompensasikan dengan harta. Maka, diperbolehkan adanya kompensasi atas tanah tersebut. Apabila orang yang memagari tadi meninggal, maka pemilikan tanah tersebut akan berpindah kepada ahli warisnya, dan mereka bisa memanagenya, sebagaimana memanage pemilikan-pemilikannya yang lain. Dan tanah tersebut bisa dibagikan kepada mereka sesuai dengan ketentuan syara'. Begitu pula orang yang diberi tanah oleh khalifah dengan cuma-cuma.

Jadi, orang yang memagari dan orang yang mendapatkan tanah dengan cuma-cuma itu tidak mempunyai sifat khusus sama sekali, dan berbeda dengan pemilik-pemilik yang lain, sehingga pencabutan tanah yang dibiarkan selama tiga tahun itu khusus berlaku bagi mereka, bukan untuk para pemilik dengan sebab-sebab pemilikan tanah yang lain. Ataupun, dengan menjadikan orang yang memagari dan orang yang diberi dengan cuma-cuma tersebut sebagai qayyid (batasan) untuk mencabut tanah tersebut, apabila tanah tersebut telah dibiarkan selama tiga tahun.

Bahwa adanya nash yang menyatakan tentang kedua pemilikan tersebut, dan bukan tentang pemilikan yang lain itu tidak bisa difahami adanya makna qayyidiyah (makna yang menjadi batasan). Sebab, hal itu bukan merupakan sifat yang memberikan pemahaman agar mencabut dari orang yang membiarkan tanahnya semata-mata karena dia adalah orang yang memagari atau orang yang diberi dengan cuma-cuma. Tidak. Akan tetapi, hal itu menunjukkan adanya orang per orang secara mutlak. Artinya, wajib mencabut tanah dari pemiliknya, apabila dia membiarkannya. Sehingga nash tersebut bermakna umum. Sehingga, penyebutan orang yang 
memagari dan orang yang diberi dengan cuma-cuma itu adalah menyebut orang per orang, bukan sebagai qayyid (batasan) yang bisa mengeliminir selain kedua orang yang disebutkan tadi.

Disamping itu, apabila ada nash yang disampaikan berkaitan dengan kasus tertentu, maka harus diteliti terlebih dahulu: Apabila kasus tadi disampaikan dengan menyertakan illat, maka nash tersebut berlaku umum untuk hal-hal yang termasuk dalam illat tersebut. Nash tersebut juga bisa difahami illat -nya, yaitu pencabutan tanah setelah tiga tahun karena tanah tersebut dibiarkan, tidak dikelola. Jadi, membiarkan tanah tersebut selama tiga tahun itu merupakan illat pencabutannya.

Oleh karena itu, illat pencabutan tanah dari orang yang memagarinya adalah karena orang yang bersangkutan telah membiarkannya selama tiga tahun. Bukan karena orang yang bersangkutan adalah orang yang memagari, juga bukan karena dia adalah orang yang memagari dus membiarkannya. Sebab, pemagaran tanah tersebut tidak menunjukkan illat pencabutannya; baik dia terlepas ataupun terkait dengan pengabaian tanah tadi. Akan tetapi, pengabaian tanah itu hanyalah illat pencabutannya. Sehingga pengabaian tanah tadi menjadi illat yang akan berputar bersama ma'lul (yang dikenai illat), baik ada dan tidaknya hukum karena illat -nya. Apabila pemilik tanah tersebut mengabaikan tanahnya selama tiga tahun, maka tanah tersebut akan dicabut dari yang bersangkutan, baik tanah tersebut asalnya dia dapatkan karena memagarinya, atau diberi dengan cuma-cuma, dengan waris, ataupun dengan cara-cara lain. Apabila orang yang 
memagari tadi tidak membiarkannya selama tiga tahun, maka tanah tersebut tidak akan diambil dari yang bersangkutan.

Lebih-lebih ihtijar (baca: pemagaran tanah) dalam pernyataan Umar: "Tidaklah ada hak bagi muhtajir (orang yang memagari)." itu adalah kinayah (makna kiasan) tentang pemilikan tanah tersebut. Sebab tradisi yang terjadi ketika itu adalah, bahwa biasanya pemilik tanah selalu memagari tanahnya, atau memagari batas-batas tanahnya dengan batu, agar diketahui bahwa tanah tersebut adalah hak miliknya, serta untuk membedakan dengan hak milik orang lain.

Sedangkan untuk bisa disebut sebagai muhtajir tidak harus meletakkan batu, tetapi kalau orang yang bersangkutan menancapkan tanaman, atau pohon pada batas-batas tanah tersebut, atau menggali batas-batasnya, atau melakukan kegiatan apapun yang menunjukkan bahwa tanah tersebut telah menjadi hak miliknya, maka semuanya tetap bisa disebut ihtijar sedangkan orang yang melakukannya disebut muhtajir . Oleh karena itu, di dalam hadits lain Rasulullah SAW bersabda: "Siapa saja yang memagari sebidang tanah dengan pagar..."

(H.R. Abu Dawud) serta hadits-hadits yang menjelaskan tentang ihtijarul ardhi (pemagaran tanah) sebagai kinayah tentang pemilikan tanah, itu menunjukkan bahwa makna kata ihtajara tadi adalah makna bahasa. Menurut bahasa, ihtajara as syai'a berarti wadh'ahu fi hijrihi adalah meletakkan sesuatu di dalam pangkuannya atau hadhanahu, merawatnya. Ihtajara al ardha maknanya hadhanaha dalam arti memilikinya. Jadi, makna hadits di atas adalah orang yang 
merawat sebidang tanah, atau orang yang memilikinya tidak lagi berhak atas tanah tersebut setelah --tanah tersebut dibiarkan-- selama tiga tahun, baik pada batas-batasnya diberi batu atau dipagari dengan pagar, atau apa saja yang bisa menunjukkan tanda-tanda pemilikan atas tanah tersebut.

Ini berkaitan dengan nash di atas. Sedangkan yang terkait dengan tindakan yang dilakukan oleh Umar, lalu sahabat-sahabat yang lain mendiamkannya, adalah Umar telah memberikan putusan tanah --yang telah diberikan oleh Rasulullah SAW kepada Muzayyinah dan dikelola oleh orang lain-- untuk orang yang mengelolanya, serta melarang Muzayyinah untuk mengambilnya. Umar mengatakan: "Siapa saja yang membiarkan sebidang tanah selama tiga tahun tidak dikelola, kemudian ada orang lain mengelolanya, maka tanah itu adalah milik orang tersebut." Pernyataan Umar ini maknanya umum, karena dia mengatakan: "Siapa saja yang membiarkan sebidang tanah." Dia mengatakan kepada Bilal Bin Al Harits Al Muzni: "Bahwa Rasulullah SAW tidak memberikan (lembah) itu kepadamu untuk kamu pagari agar orang-orang tidak bisa mengambilnya, akan tetapi beliau memberikan kepadamu agar kamu menggarapnya. Maka, ambillah dari tanah tersebut yang sanggup kamu kelola, dan yang lain kamu kembalikan." Riwayat ini disampaikan oleh Abu Ubaidah di dalam kitab Al Amwal. Kemudian Umar betul-betul mengambil tanah yang tidak sanggup digarap oleh Bilal. Sehingga pen -takhshis -an kasus tersebut untuk tanah yang diberikan dengan cuma-cuma saja --sementara tidak ada mukhashis (dalil yang mengkhususkan)-- tentu 
tidak diperbolehkan, akan tetapi maknanya tetap bersifat umum. Adapun kasus yang terjadi pada orang yang diberi dengan cuma-cuma itu adalah gambaran tentang suatu realitas, bukan sebagai qayyid (batasan) kasus ini.

Jadi, tiap pemilik tanah yang membiarkan tanahnya selama tiga tahun, maka tanahnya akan dicabut dan diberikan kepada orang lain, dari mana pun asal pemilikan tanah tersebut. Hal ini tidak bisa dianggap telah mengambil harta orang lain dengan cara yang tidak sah. Karena syara' telah menentukan pemilikan tanah tersebut mempunyai makna yang berbeda dengan makna pemilikan harta bergerak, dus berbeda dengan makna pemilikan harta tetap. Sebab, syara' telah menjadikan pemilikan atas tanah tersebut adalah untuk ditanami. Jadi, apabila tanah tersebut dibiarkan dalam batas waktu yang telah ditentukan oleh syara', maka makna pemilikan atas tanah tersebut hilang dari pemiliknya. Dan syara' telah menentukan pemilikan atas tanah untuk ditanami tersebut dengan cara dikelola. Sedangkan untuk memilikinya bisa dengan diberi secara cuma-cuma, waris, membeli dan sebagainya. Kemudian tanah tersebut akan terlepas dari pemiliknya, apabila tanah tersebut dibiarkan. Semuanya itu adalah agar tanah tersebut selalu ditanami dan dikelola secara optimal.

\section{Larangan Menyewakan Tanah}

Seorang pemilik tanah tidak diperbolehkan secara mutlak menyewakan tanahnya untuk pertanian, baik pemiliknya memiliki lahan dan kegunaan (utility)-nya sekaligus, ataupun hanya memiliki kegunaan (utility)-nya saja, artinya baik tanah 
tersebut statusnya usyriyah ataupun kharajiyah, baik sewanya berupa uang ataupun yang lain. Begitu pula, ia juga tidak diperbolehkan untuk menyewakan tanah untuk pertanian dengan sewa yang berupa makanan ataupun yang lain, yang dihasilkan oleh pertanian tersebut, atau apa saja yang dihasilkan dari sana, sebab semuanya merupakan ijarah - Padahal menyewakan tanah untuk pertanian itu secara mutlak hukumnya haram. Di dalam Shahih Bukhari dijelaskan, bahwa Rasulullah SAW bersabda:

"Siapa yang mempunyai sebidang tanah, hendaknya dia menanaminya, atau hendaknya diberikan kepada saudaranya. Apabila dia mengabaikannya, maka hendaknya tanahnya diambil."

Di dalam Shahih Muslim disebutkan:

"Rasulullah SAW melarang pengambilan sewa atau bagian atas tanah."

309

Di dalam Sunan An Nasai disebutkan:

"Rasulullah SAW melarang menyewakan tanah. Kami bertanya: 'Wahai Rasulullah, kalau begitu kami akan menyewakannya dengan bibit.' Beliau menjawab: 'Jangan.' Bertanya (sahabat): 'Kami akan menyewakannya dengan jerami.' Beliau menjawab: 'Jangan.' Bertanya (sahabat): 'Kami akan menyewakannya dengan sesuatu yang ada di atas rabi' (danau) yang mengalir.' Beliau menjawab: 'Jangan. Kamu tanami atau kamu berikan tanah itu kepada saudaramu.'" 
Rabi' adalah sungai kecil atau danau. Artinya, kami akan menyewakannya dengan sewa tanaman yang ada di atas Rabi', maksudnya di samping air.

Ada hadits shahih dari Nabi SAW: "Bahwa beliau melarang pengambilan sewa dan bagian atas suatu tanah, serta menyewakan dengan sepertiga ataupun dengan seperempat." Imam Abu Dawud meriwayatkan dari Rafi' Bin Khudaij, bahwa Rasulullah SAW bersabda:

"Siapa saja yang mempunyai tanah, hendaknya menanami tanahnya, atau hendaknya (diberikan agar) ditanami oleh sudaranya. Dan janganlah menyewakannya dengan sepertiga, seperempat, maupun dengan makanan yang sepadan."

Imam Bukhari meriwayatkan dari Nafi' bahwa Abdullah Bin Umar diberitahu Rafi' Bin Khudaij: "Bahwa Nabi SAW melarang menyewakan lahan pertanian." Kemudian Ibnu Umar pergi menemui Rafi', lalu aku bersamanya, dan kami menanyainya. Dia berkata: "Nabi SAW telah melarang sewa lahan pertanian." Imam Bukhari meriwayatkan dari Salim, bahwa Abdullah Bin Umar telah meninggalkan sewa tanah.

Hadits-hadits di atas tegas menunjukkan larangan Rasulullah SAW terhadap penyewaan tanah. Larangan tersebut, meski hanya menunjukkan adanya perintah untuk meninggalkannya, namun ternyata di sana ada qarinah (indikasi) yang menjelaskan tentang adanya larangan yang tegas. Mereka bertanya kepada Rasul: "Kami akan menyewakannya dengan bibit." Beliau menjawab: "Jangan." Mereka bertanya: "kami akan menyewakannya 
dengan jerami." Beliau tetap menjawab: "Jangan." Mereka bertanya lagi: "Kami akan menyewakannya dengan rabi' (danau)." Beliau tetap menjawab: "Jangan." Kemudian beliau pertegas dengan sabdanya: "Tanamilah, atau berikanlah kepada saudaramu." Hadits ini jelas sekali, bahwa beliau melarang terus-menerus, yang berarti menunjukkan adanya ta'kid (baca: penegasan). Disamping itu, ta'kid di dalam bahasa Arab, adakalanya dengan lafadz yaitu mengulang pemakaian lafadz sebelumnya, dan adakalanya dengan makna. Dalam hadits tersebut, lafadz yang menunjukkan larangan itu ternyata diulang-ulang, sehingga --dengan pengulangan itu-- menimbulkan makna ta'kid .

Sedangkan Rasulullah yang telah menyewakan tanah Khaibar dengan separo itu tidak termasuk dalam pembahasan ini. Karena tanah Khaibar itu berupa rimba belantara, bukan berupa tanah yang bersih. Terbukti dengan riwayat dari Ibnu Ishaq di dalam kitab Sirah dari Abdullah Bin Rawwahah Bin Abi Bakar: "Bahwa Rasulullah SAW pernah mengirim Abdullah Bin Rawwahah kepada penduduk Khaibar untuk menjadi seorang kharish antara kaum muslimin dengan orang-orang Yahudi. Dia kemudian memperkirakan untuk mereka...

Lalu Abdullah Bin Rawwahah meninggal --semoga Allah memberikan rahmat kepadanya-- kemudian setelah Abdullah Bin Rawwahah, Jabbar Bin Shakhr Bin Umayah Bin Khansa' saudara Bani Salamah-lah yang menjadi kharish untuk mereka." Kharish adalah orang yang memperkirakan hasil buah-buahan, sementara buah tersebut masih berada di atas dahan sebelum dipetik. 
Riwayat ini jelas menunjukkan, bahwa tanah Khaibar itu berupa rimba belantara, bukan tanah yang bersih. Sedangkan tanaman yang terdapat di permukaan tanah tersebut lebih sedikit ketimbang hamparan pepohonan, sehingga tanaman tersebut mengikuti pepohonan tadi, atau lebih dominan pohonnya. Oleh karena itu, yang dilakukan Rasul terhadap tanah Khaibar itu tidak termasuk menyewakan tanah, melainkan mengairi --dengan pembagian separo hasil buahnya untuk yang menyirami-- tanah tersebut. Sedangkan status hukumnya menyirami tanah tersebut mubah. Disamping, setelah larangan Rasulullah SAW tersebut ada sahabat yang melarang menyewakan tanah, di antara mereka adalah Abdullah Bin Umar. Hal ini membuktikan, bahwa mereka memahami keharaman menyewakan tanah. Hanya masalahnya, keharaman menyewakan tanah tersebut berlaku apabila tanah tersebut disewa untuk pertanian. Namun, apabila menyewakan tanah untuk keperluan selain pertanian, hukumnya mubah. Sebab hukumnya memang mubah bagi seseorang menyewakan tanah untuk kandang ternak, tempat memerah susu, ataupun gudang penyimpanan barang, atau untuk dimanfaatkan dengan sewa tertentu selain untuk pertanian. Sebab, larangan penyewaan tanah tersebut merupakan larangan penyewaan tanah untuk pertanian, sebagaimana yang bisa ditemukan dari banyak hadits-hadits shahih yang ada. Hukum-hukum tanah serta hal-hal yang terkait dengan pertanahan ini menjelaskan tentang mekanisme yang dipergunakan oleh As Syari' untuk mengikat orang Islam ketika bekerja untuk mengembangkan pemilikannya melalui pertanian. 
154 


\section{JUAL BELI DAN BERPRODUKSI}

\section{Jual Beli}

Allah SWT telah menjadikan harta sebagai salah satu sebab tegaknya kemaslahatan manusia di dunia. Untuk mewujudkan kemaslahatan tersebut, Allah SWT telah mensyari'atkan cara perdagangan tertentu. Sebab, apa saja yang dibutuhkan oleh setiap orang tidak bisa dengan mudah diwujudkan setiap saat, dan karena mendapatkannya dengan menggunakan kekerasan dan penindasan itu merupakan tindakan yang merusak, maka harus ada sistem yang memungkinkan tiap orang untuk mendapatkan apa saja yang dia butuhkan, tanpa harus menggunakan kekerasan dan penindasan. Itulah perdagangan dan hukum-hukum jual beli.

Allah SWT berfirman:

"Hai orang-orang yang beriman, janganlah kalian saling memakan harta sesama kalian dengan jalan yang batil, kecuali dengan jalan perdagangan yang berlaku dengan suka sama-suka di antara kalian." (Q.S. An Nisa': 29)

Perdagangan itu ada dua macam: perdagangan yang halal, yang dalam bahasa syara' disebut bai' (baca: jual-beli) dan perdagangan yang haram, yang disebut riba. Masing-masing --baik bai' maupun riba-- adalah termasuk dalam katagori perdagangan. 
Allah SWT telah menjelaskan tentang ihwal orang-orang kafir, dengan meng -counter mereka, karena membedakan antara bai' dengan riba tersebut dengan mengikuti akal. Allah SWT berfirman:

"Hal itu adalah karena mereka menganggap bai' (jual-beli) itu sama dengan riba." (Q.S. Al Baqarah: 275)

Kemudian Allah SWT memilah antara keduanya dengan perbandingan halal dan haram, dengan firman-Nya:

"Padahal Allah telah menghalalkan bai' (jual-beli) dan mengharamkan riba." (Q.S. Al Baqarah: 275)

Kita tahu bahwa masing-masing, baik jual-beli maupun riba, adalah jenis perdagangan. Dan perdagangan yang halal di antara keduanya menurut syara', yaitu jual-beli, hukumnya adalah mubah. Sedangkan untuk melakukan jual-beli itu harus menggunakan dua lafadz, yang salah satunya menunjukkan ijab sementara yang lain menunjukkan qabul ; yaitu aku menjual dan aku membeli, atau yang senada dengan kedua pernyataan ini, baik dari segi ungkapan maupun praktiknya. 
Seorang pemilik barang bisa melakukan penjualan sendiri, atau melalui wakil yang menggantikannya, atau delegasi yang ditugasi untuk melakukan penjualan tersebut. Diperbolehkan juga mengontrak seorang ajiir untuk melakukan penjualan, dengan syarat upahnya harus jelas. Apabila pemilik barang tadi mengontrak ajiir dengan upah yang diambilkan dari laba penjualan tersebut, maka ajiir tersebut statusnya adalah syarik mudharib (pesero yang merupakan pengelola), dan terhadap orang yang bersangkutan harus diberlakukan hukum mudharib (pesero) bukan hukum ajiir. Diperbolehkan pula melakukan pembelian harta tertentu sendiri, atau melalui wakilnya, atau utusannya, ataupun mengontrak orang untuk membelikannya.

Walhasil, perdagangan itu hukumnya mubah. Dan perdagangan tersebut merupakan salah satu bentuk pengembangan kepemilikan. Ketentuannya juga sangat jelas dalam hukum-hukum bai' (jual-beli) dan syirkah (perseroan). Perdagangan tersebut juga telah dinyatakan di dalam Al Qur'an dan Al Hadits. Allah SWT berfirman:

"Kecuali jika mu'amalah itu adalah perdagangan tunai yang kamu jalankan di antara kamu, maka tak ada dosa bagi kamu, (jika) kamu tidak menulisnya." (Q.S. Al Baqarah: 282)

Rufa'ah meriwayatkan, bahwa dia telah keluar bersama Nabi SAW ke mushalla. Kemudian beliau menyaksikan ada orang saling melakukan jual-beli. Beliau bersabda: "Hai para pedagang." Mereka kemudian mengangkat kepala dan pandangan mereka tertuju kepada beliau, untuk memenuhi panggilan beliau. Beliau bersabda: 
"Bahwa para pedagang nanti akan dibangkitkan pada hari kiamat sebagai orang yang durjana, kecuali pedagang yang bertakwa kepada Allah, taat dan jujur." (H.R. Imam At Tirmidzi)

Abu Sa'id meriwayatkan dari Nabi SAW bersabda:

"Pedagang yang jujur lagi terpercaya, kelak akan bersama-sama para nabi dan orang-orang yang jujur, serta para syuhada'." (H.R. Imam At Tirmidzi)

Sedangkan perdagangan itu bisa dipilah lagi menjadi dua, yaitu perdagangan dalam negeri dan perdagangan luar negeri. Perdagangan dalam negeri adalah traksaksi penjualan dan pembelian yang terjadi di antara individu terhadap barang yang menjadi milik mereka; baik hasil produksi mereka maupun hasil produksi orang lain; baik yang berupa hasil produksi pertanian ataupun industri, namun pertukarannya terjadi di dalam negeri mereka. Perdagangan dalam negeri tersebut tidak ada masalah, dan tidak ada ketentuan-ketentuan yang macam-macam, selain hukum-hukum jual-beli yang telah dinyatakan oleh syara'. Sedangkan barang, jenis barang serta pengiriman barang dalam negeri, dari satu negara ke negara lain, adalah diserahkan kepada masing-masing orang yang akan melakukan perdagangan, sesuai dengan ketentuan hukum-hukum syara'. Dalam hal ini, negara tidak berhak ikut campur dalam perdagangan dalam negeri, selain hanya berhak untuk memberikan pengarahan saja. 
Adapun perdagangan luar negeri adalah pembelian barang dari luar negeri dan penjualan barang dalam negeri ke luar negeri; baik barang tersebut merupakan hasil produksi pertanian ataupun hasil industri. Perdagangan luar negeri inilah yang harus tunduk secara langsung kepada arahan politik negara. Negaralah yang mengendalikan secara langsung arahan untuk memasukkan dan mengeluarkan barang, termasuk terhadap para pedagang kafir harbi (kafir musuh) maupun kafir mu'ahid (kafir yang terikat perjanjian).

\section{Berproduksi}

Istishna' (berproduksi) adalah apabila ada seseorang memproduksi bejana, mobil atau apa saja yang termasuk dalam katagori produksi. Berproduksi itu hukumnya mubah dan jelas berdasarkan As Sunnah. Sebab, Rasulullah SAW pernah membuat cincin. Diriwayatkan dari Anas yang mengatakan: "Nabi SAW telah membuat sebuah cincin." (H.R. Imam Bukhari). Dari Ibnu Mas'ud: "Bahwa Nabi SAW telah membuat sebuah cincin yang terbuat dari emas." (H.R. Imam Bukhari). Beliau juga pernah membuat mimbar. Dari Sahal berkata: "Rasulullah SAW telah mengutus kepada seorang wanita, (kata beliau): 'Perintahkan anakmu si tukang kayu itu untuk membuatkan sandaran tempat dudukku, sehingga aku bisa duduk di atasnya." (H.R. Imam Bukhari). Pada masa Rasulullah, orang-orang biasa memproduksi barang, dan beliau pun mendiamkan aktivitas mereka. Sehingga diamnya beliau menunjukkan adanya taqrir (baca: pengakuan) beliau terhadap aktivitas berproduksi mereka. 
Status taqrir dan perbuatan Rasul itu sama dengan sabda beliau, artinya sama-sama merupakan dalil syara'.

Sedangakan terhadap sesuatu yang disepakati dalam transaksi adalah al mustashni' fihi (barang yang diproduksi), seperti cincin, mimbar, almari, mobil dan sebagainya. Maka dalam hal semacam ini, berproduksi itu statusnya sama dengan transaksi jual beli, bukan transaksi ijarah. Adapun, kalau seseorang mendatangkan ahli pembuat barang agar membuatkan barang tertentu untuk dirinya, maka dalam hal semacam ini bisa termasuk dalam katagori transaksi ijarah .

Adapun industri dari segi industri itu sendiri merupakan salah satu asas penting dalam kehidupan perekonomian masyarakat, bangsa dan umat. Pada mulanya industri ini hanya terbatas pada kerajinan tangan (handicraft system) saja, baru setelah manusia berhasil memanfaatkan uap untuk menggerakkan alat mekanik, maka mesin-mesin otomatis --yang digerakkan oleh uap-- tersebut secara perlahan menggeser posisi kerajinan tangan (handicraft system). Ketika penemuan-penemuan baru bermunculan, maka terjadilah revolusi industri yang spektakuler, sehingga laju produksi terus meningkat yang tidak pernah terbayangkan sebelumnya. Sehingga industri dengan menggunakan mesin (factory system) ini kemudian menjadi salah satu asas kehidupan perekonomian.

Hukum-hukum yang berhubungan dengan industri dengan mesin (factory system) atau kerajinan tangan (handicraft system) itu tidak bisa lepas dari hukum-hukum perseroan, ijarah, jual-beli dan perdagangan luar negeri. Dari segi pendirian industri, adakalanya industri tersebut didirikan dengan modal satu orang, namun ini amat langka. Umumnya, 
industri tersebut didirikan dengan modal beberapa orang yang saling melakukan perseroan untuk mendirikan industri tersebut. Sehingga pada saat itu, berlakulah hukum-hukum perseroan secara Islam dalam pendirian industri tersebut. Sedangkan dari segi kegiatannya, seperti kegiatan administrasi, kerja, berproduksi ataupun yang lain, itu bisa diberlakukan hukum-hukum ijarah atas seorang ajiir . Adapun dari segi pemasaran hasil produksinya, bisa diberlakukan hukum-hukum jual beli dan perdagangan luar negeri, dus tidak boleh melakukan penipuan, baik yang berbentuk tadlis maupun ghaban, dan penimbunan, sebagaimana tidak diperbolehkan untuk mempermainkan harga dan hukum-hukum jual beli yang lain. Sedangkan pengarahan terhadap hasil produksi, baik berupa produksi kecil maupun besar, sebelum memproduksi suatu produk, itu bisa diberlakukan hukum-hukum berproduksi. Syara' telah menghukumi adanya keterikatan industriawan dengan barang yang diproduksi, atau tidak. 


\section{Daftar Pustaka}

Abdul Husin at-Tariqi, Abdullah, (2004), Ekonomi Islam, Prinsip, Dasar dan Tujuan, Magistra Insani, Yogyakarta.

Al-Husaini, Taqiyuddin Abubakar, (1997), Kifayatul Ahkyar, Bagian 2, Bina IImu, Surabaya.

Antonio, Muh. Syafii, (2001), Bank Syariah dari Teori ke

Praktik, Gema Insani , Jakarta. Beekun, Rafiq Issa, (1997), Islamic Business Ethics, The Islamic International Institute of Islamic Thought, Virginia

Bertrand Badie; Dirk Berg-Schlosser; Leonardo Morlino (2011). International Encyclopedia of Political Science. SAGE Publications, Inc.

Bintoro, Muchamad Imam, (2005) : The Gold Dinar Sistem : Prospects and Challenges, Makalah kajian akademik, tgl 8 Juli 2005, Prodi Manajemen FE UMY.

Chapra, Umer. (2000), The Future of Economics : An Islamic Perspective, The Islamic Foundation, UK. ( 2000), Islam dan Tantangan Ekonomi, Gema Insani, Jakarta.

Dumairy, (1995), Perekonomian Indonesia, Erlangga, Jakarta. Hafidhuddin, Didin, (2002), Zakat Dalam Perekonomian Modern, Gema Insani, Jakarta. Heilbroner, Robert L, (1982) , Tokoh-tokoh Besar Pemikir Ekonomi, UI Press , Jakarta. Hudiyanto, (2002), Keluar dari Ayun Pendulum Kapitalisme Sosialisme, PPE UMY, Yogyakarta.

Istanto, Ahmad. Kebijakan Fiskal Pada Awal Pemerintahan Islam, 2013, Jakarta. Hal. 53

Karim, Adiwarman Aswar, (2001), Ekonomi Islam Suatu Kajian Kontemporer, Gema Insani, Jakarta. 
(2002), Ekonomi Mikro Islami, IIIT

Indonesia, Jakarta. Majid, M. Nazori, (2003),

Pemikiran Ekonomi Islam Abu Yusuf : Relevansinya denganEkonomi Kekinian, PSEI, Yogyakarta.

McLaughlin, Paul (2007) Anarchism and Authority: A Philosophical Introduction to Classical Anarchism. AshGate. 2007.

Muhamad, (2002), Dasar-dasar Keuangan Islami,

Ekonisia,Yogyakarta.

O'Hara, Phillip (September 2003). Encyclopedia of Political Economy, Volume 2. Routledge.

Pierre Leroux dan J. Regnaud (1985) dalam I'Encyclopédie Nouvelle A History of Socialist Thought, Volume 1

Rais, M Amien, (1985), " Prinsip Egalitarian dalam Sistem

Ekonomi Islam, Mencari Sistem Ekonomi Islam", LPPM UII, Yogyakarta.

Rocker, Rudolf (2004). Anarcho-Syndicalism: Theory and Practice. AK Press.

Suherman Rosyidi. (2011) Pengantar Teori Ekonomi. Jakarta:

Raja Grafindo Persada. Hal. 32

Scott, John (2005). Industrialism: A Dictionary of Sociology. Oxford University Press.

Saddam, Muhammad, (2003), Ekonomi Islam, Taramedia, Jakarta.

Sheldon, Garrett Ward (2001). Encyclopedia of Political Thought. Fact on File. Inc.

Sudarsono, Heri, (2003), Bank \& Lembaga Keuangan Syariah : Deskripsi dan Ilustrasi , Ekonisia, Yogyakarta.

Qardhawi, Yusuf. (2001), Norma dan Etika Ekonomi Islam, , Gema Insani, Jakarta.

Rahardjo, M. Dawam, (1999), Islam dan Transformasi Sosial-Ekonomi, Pustaka Pelajar, Yogyakarta. 
Tasmara, Toto, (2002), Membudayakan Etos Kerja Islami, Gema Insani, Jakarta Undang-undang Republik Indonesia No. 10 Tahun 1998, tanggal 10 Nopember 1998, tentang Penbankan.

Williams, Raymond (1983). "Capitalism". Keywords: A vocabulary of culture and society, revised edition. Oxford University Press

Yuliadi, Imamudin, (2001), Ekonomi Islam sebuah pengantar, LPPI, Yogyakarta.

Zuhri, Muh, (1996), Riba dalam Al-Qur"an dan Masalah Perbankan, Raja Grafindo Persada, Jakarta. (2001), Islam Untuk Disiplin Ilmu Ekonomi, Departeman Agama RI,

\section{BIODATA PENULIS}

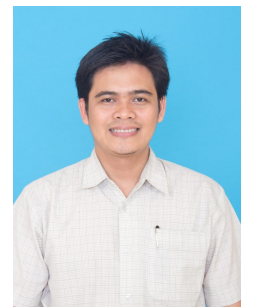

Dr. Kumara Adji Kusuma, S.FIL.I, CIFP, dilahirkan di Surabaya, 05 Oktober 1978. Pada tahun 2004, penulis mendapatkan gelar Sarjana Filsafat Islam dari Institut Agama Islam Negeri Sunan Ampel. Penulis melanjutkan pendidikan strata 2 pada bidang keuangan Islam dengan program beasiswa dari Bank Negara Malaysia pada kampus Internationa Center for Education of Islamic Finance (INCEIF). Tahun 2018, penulis menuntaskan studi S3 dalam bidang Ekonomi Islam pada Sekolah Pascasarjana Universitas Airlangga. Penulis mengawali karirnya sebagai Dosen di prodi pendidikan Ekonomi Islam pada Universitas Muhaammdiyah Sidoarjo. 
Beberapa penelitian dan penerbitan telah dilakukan hingga sekarang 